\title{
رؤية بلاغية لوصف أبليس في آيات القرآن الكريم
}

\section{Rhetorical vision of describing the Devil in the verses of the Noble Qur'an}

\author{
إعضلات \\ عبير بنت إبراهيه بن عبدالله الزبيدي \\ Doi:10.12816/jnal.2021.144692
}

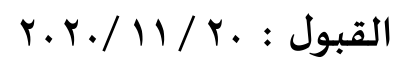

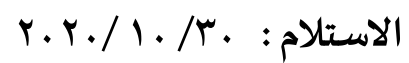

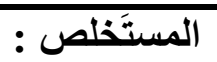

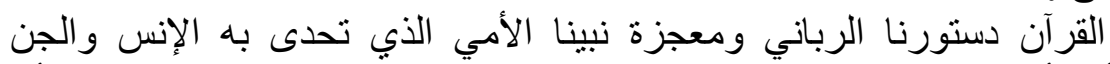

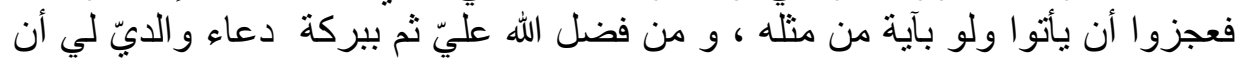

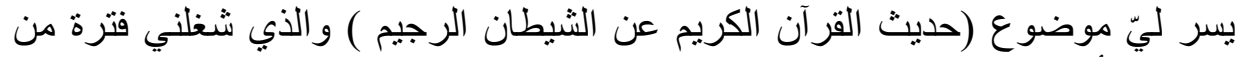

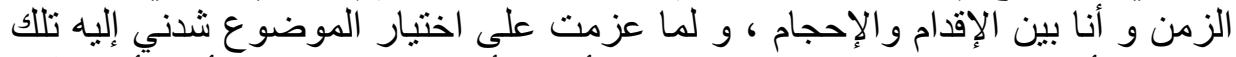

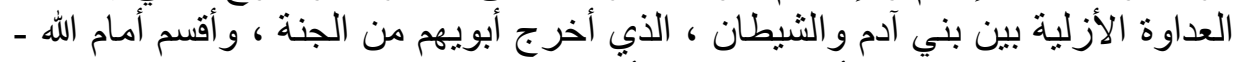

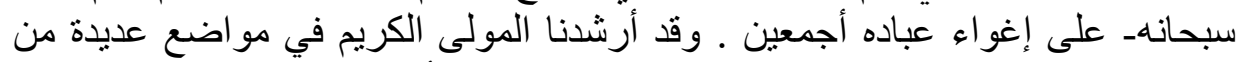

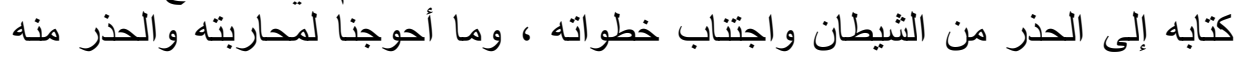

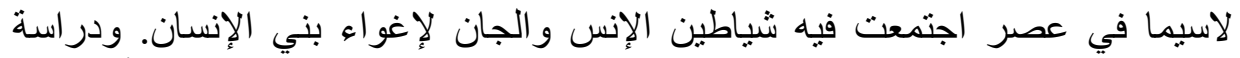

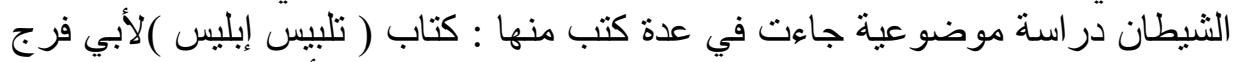

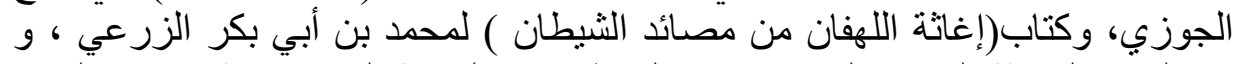

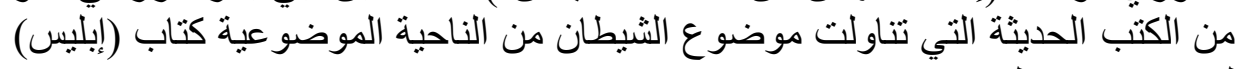

\section{Abstract:}

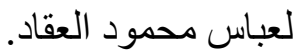

The Qur'an is our divine constitution and the miracle of our illiterate prophet who challenged mankind and the jinn, and they were unable to come even with a verse of something like him, and from the grace of God to me, then with the blessing of my parents 'supplication for me, the subject of (the Noble Qur'an hadith about the accursed Satan) which occupied me for a period of time while I was between boldness And reluctance, and when I decided to choose the subject, I was drawn to that eternal enmity between the children of Adam and Satan, who drove their parents 
out of Paradise and swore before God - Glory be to Him - to seduce all His servants. The Honorable Lord has guided us in many places of his book to beware of Satan and avoid his steps, and how much we need to fight him and beware of him, especially in an age in which the demons of mankind and the elves gathered to seduce human beings. The study of the Devil is an objective study that came in several books, including: The book "Dressing the Devil" by Abu Faraj Al-Jawzi.

\section{التمهيد :}

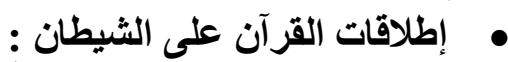

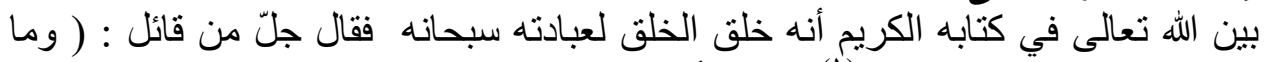

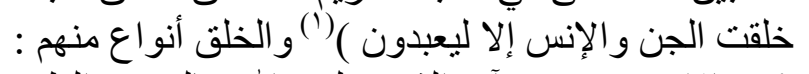

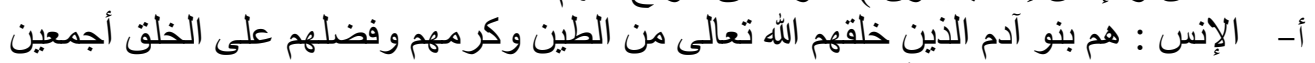

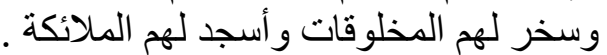

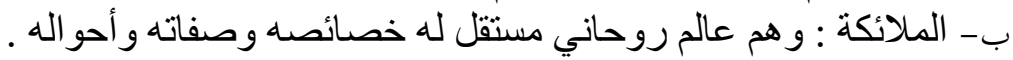

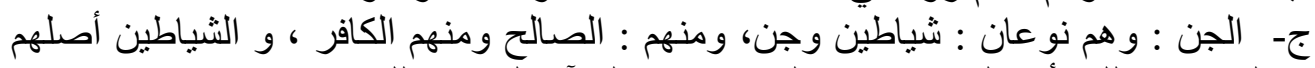

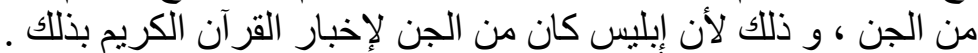

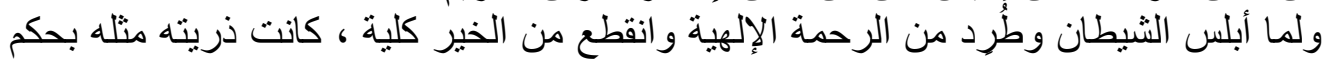

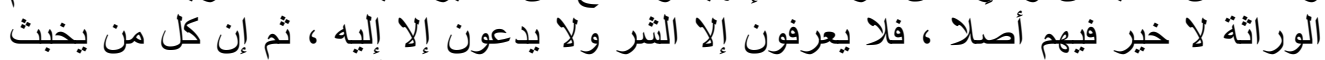

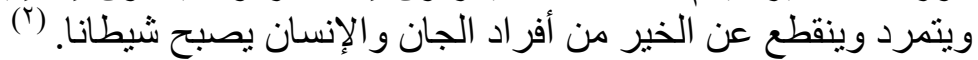

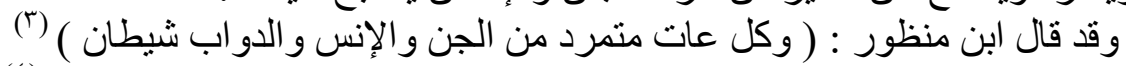

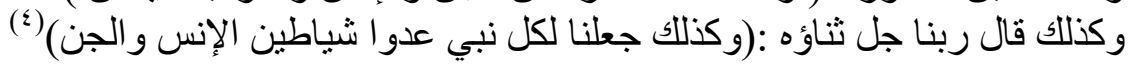

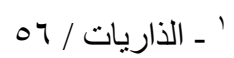

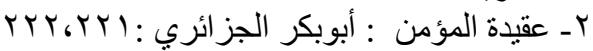

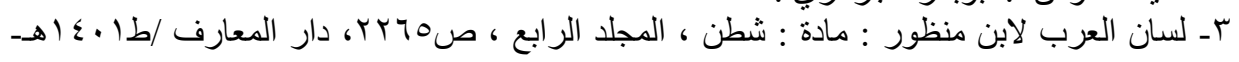


"و إنما سمي المتمرد من كل شيء شيطانا لمفارقة أخلاقه و أفعاله أخلاق سائر جنسه

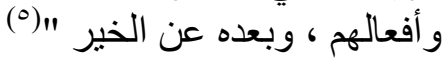

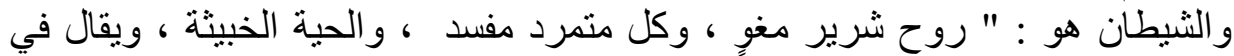

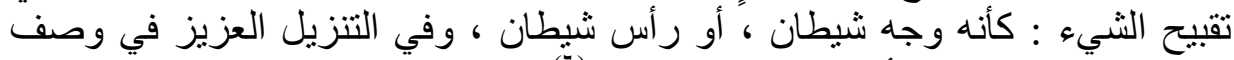

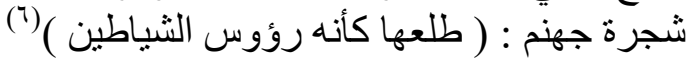

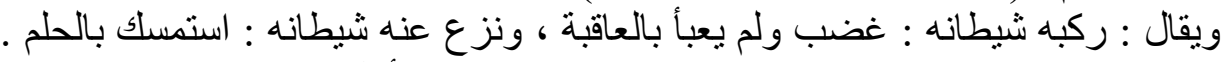

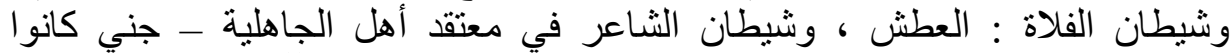

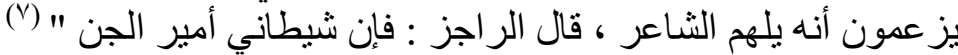

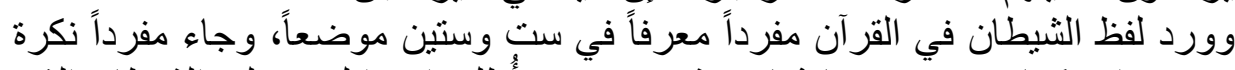

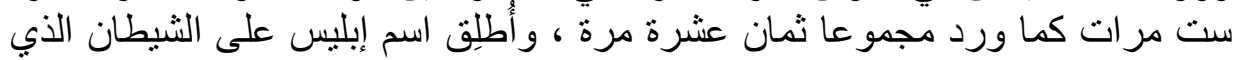

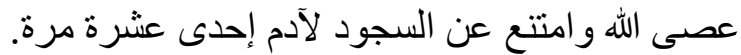

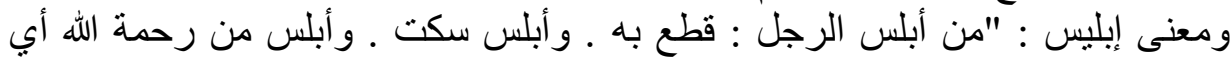

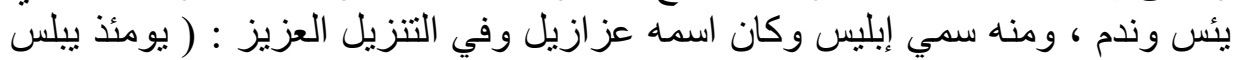

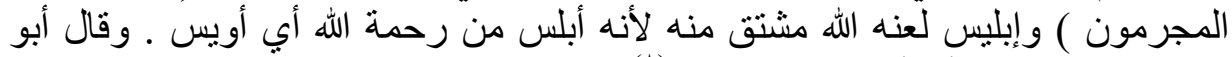

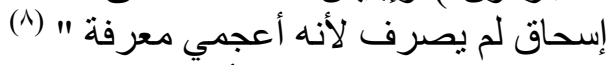
وللعلماء في حقيقة إبليس رأيان : أله أعدي :

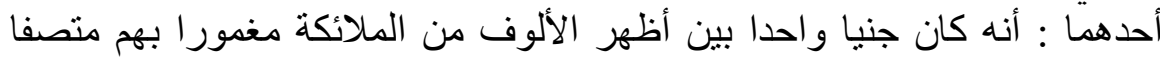

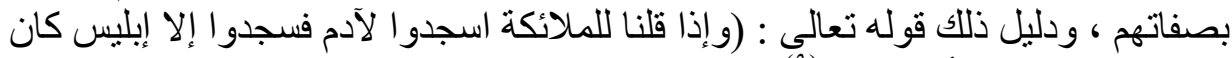

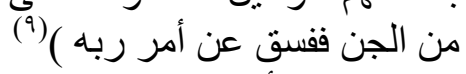

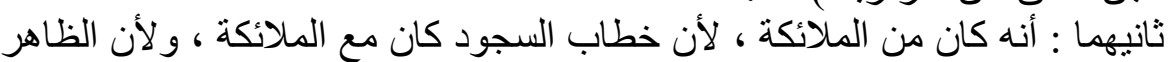

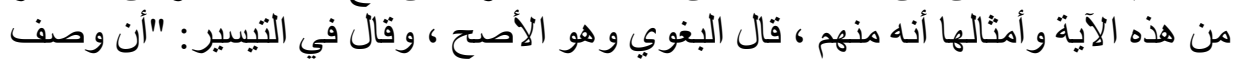

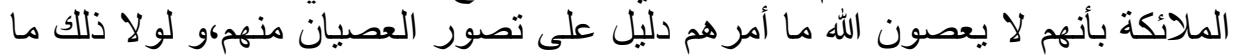

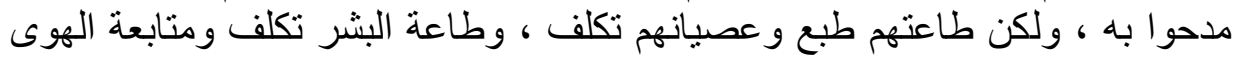

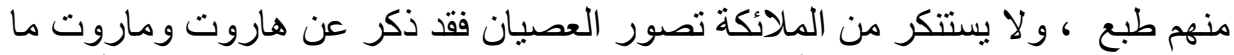
ذكر ، وليس هنالك دليل على أن بين الملائكة و الجن فروقا جوهرية بها يمتاز أحدهما

$$
\begin{aligned}
& \text { ه - جامع البيان (1/1 ) ابن جرير الطبري } \\
& 70 \text { ـ الصافات } 70
\end{aligned}
$$

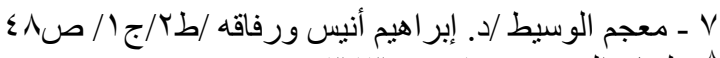

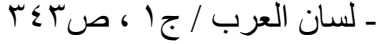

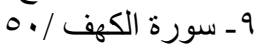


عن الآخر ، بل هي فروق في الأوصاف فقط ، و و الجميع من عالم الغيب لا نعلم حقائقها

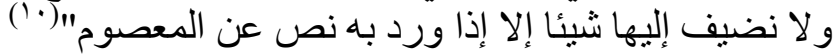

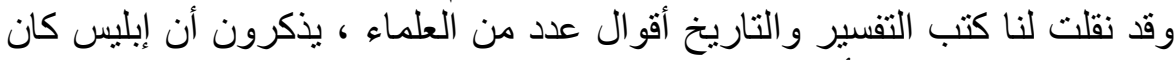

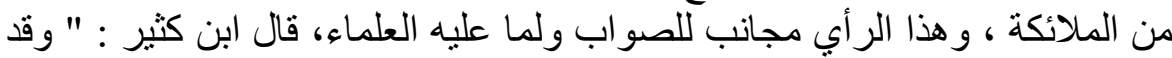

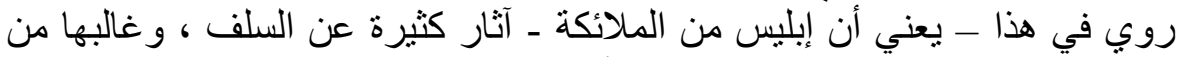

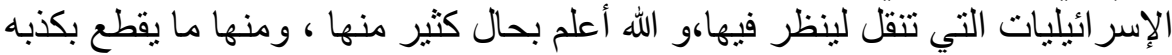

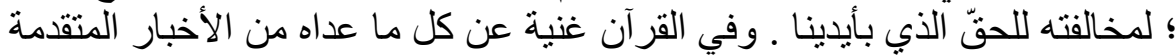

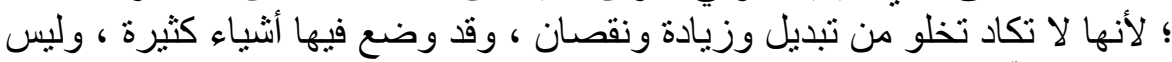

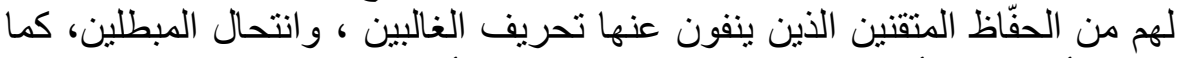

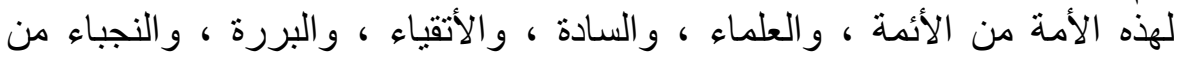

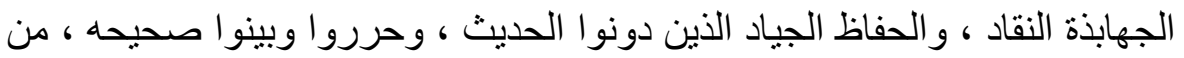

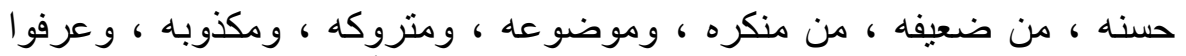

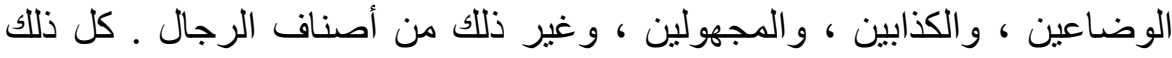

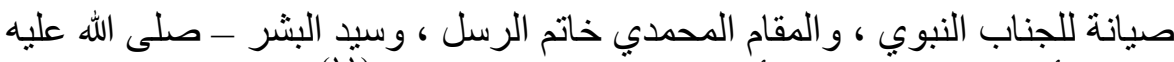

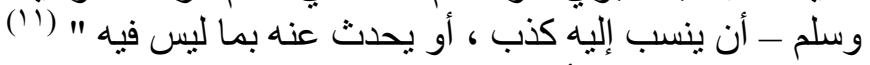

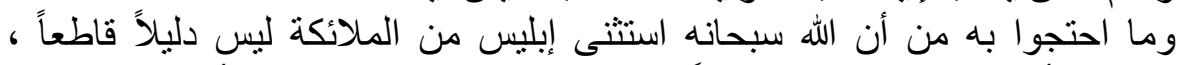

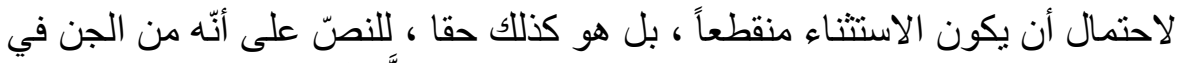

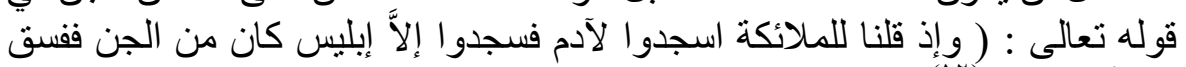

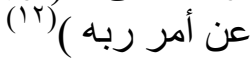

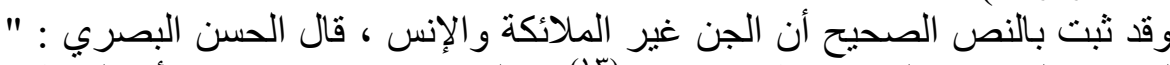

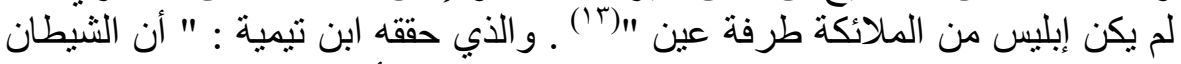

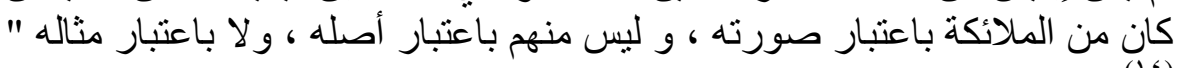
والأرجح أن إبليس لم يكن من الملائكة بل هو من الجن ، كما صرح القرآن الكريم

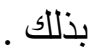
الفرق بين الجن والثياطين :

. 1 ـ تفسير المراغي / أحمد مصطفى المراغي / شركة مكتبة ومطبعة مصطفى الحلبي / طا ،جا

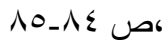

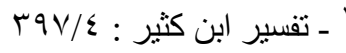
با 11 ـ الكهف /

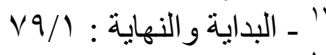

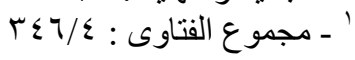


"الأكثر أن يخص باسم الجن نوع لا يخالط خواطر البشر ، ويخص باسم الثياطين نوع

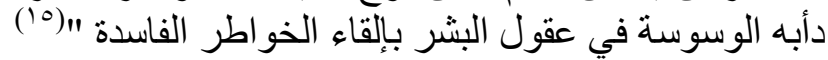

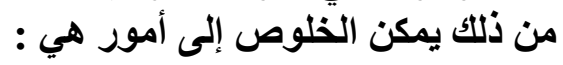

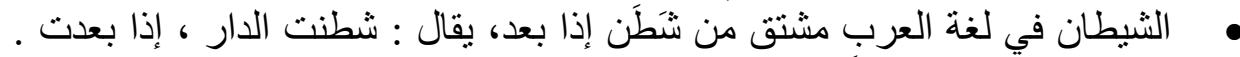

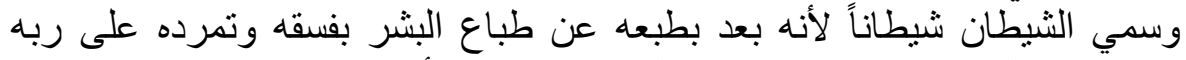

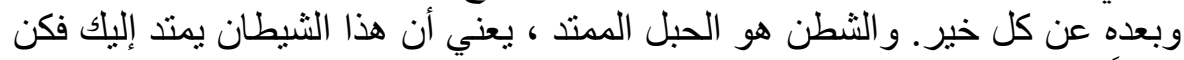

$$
\text { حذر اً منه. }
$$

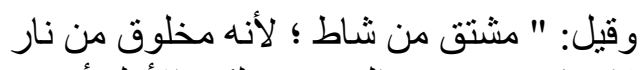

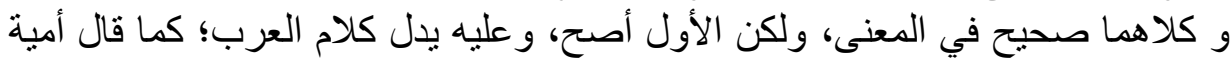

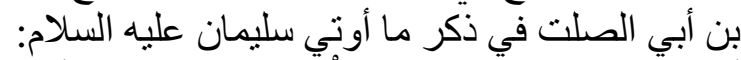

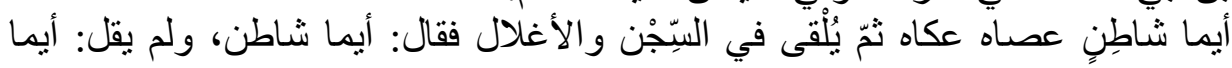
شائط وقال سيبويه: العرب تقول: تشيطن فلان إذا فَعَل فِعْل الثبطان ولو كان من شاط لقالوا: تشيط.

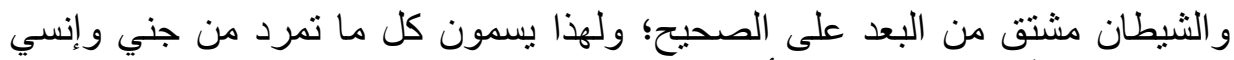

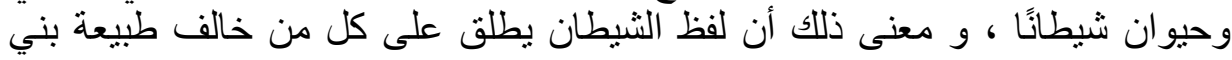

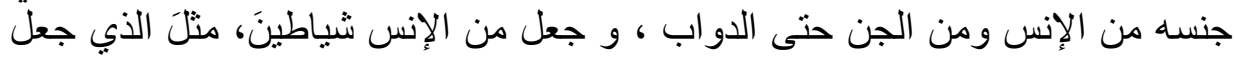

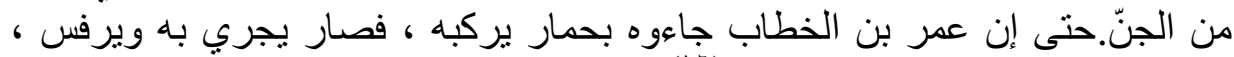

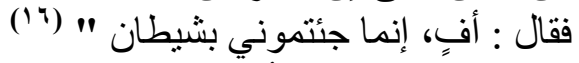

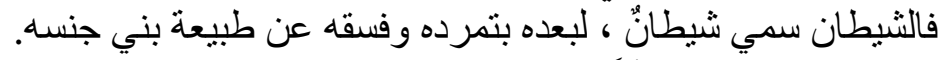

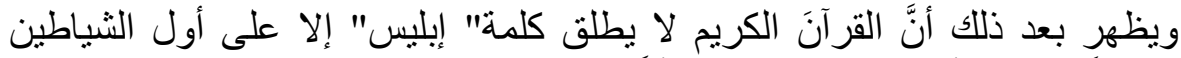

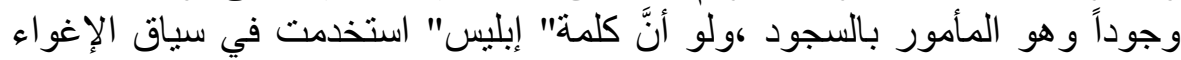

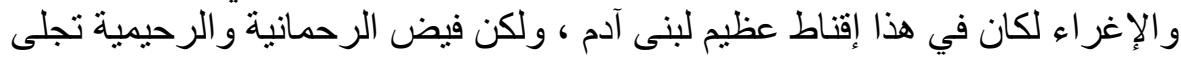

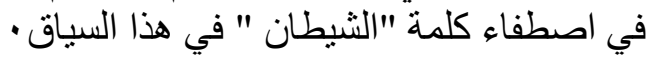

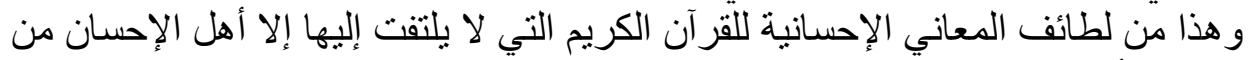

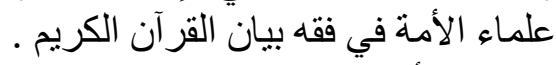
الفصل الأول مواضع حديث القرآن عن الشيطان وعلاقتها بنسث بناء السورة القرآنية 1- الشيطان في قصص الأنبياء : 


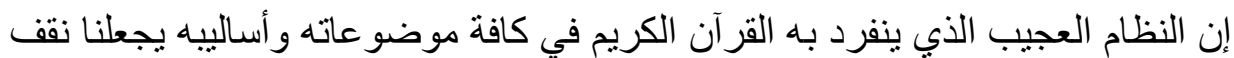

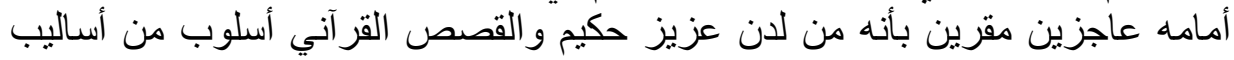

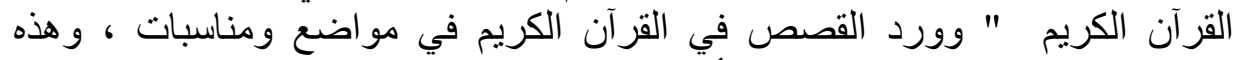

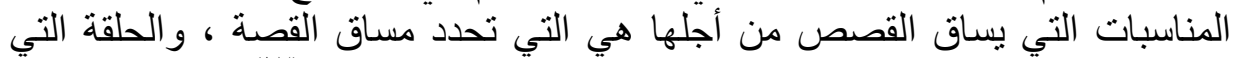

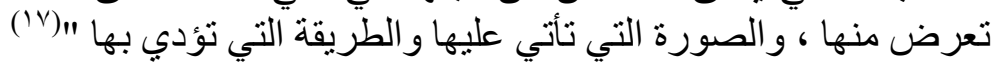

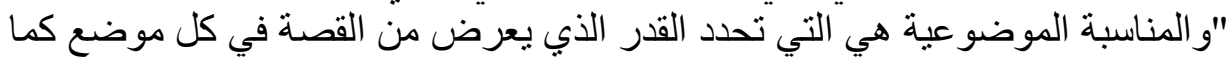

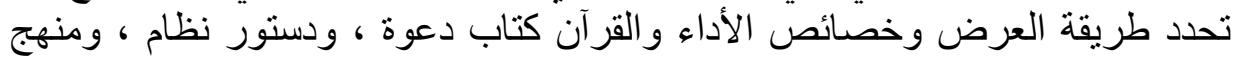

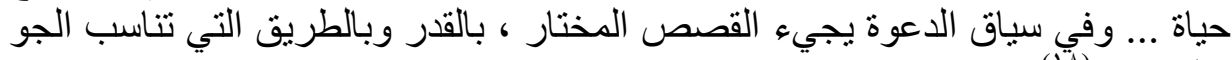

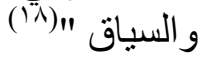

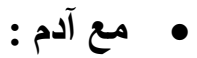

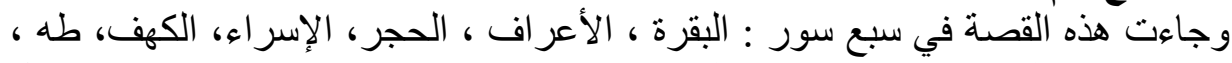

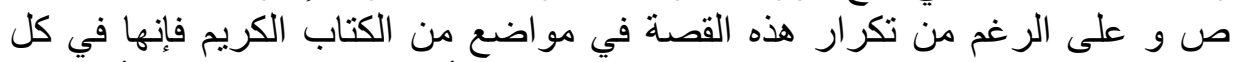

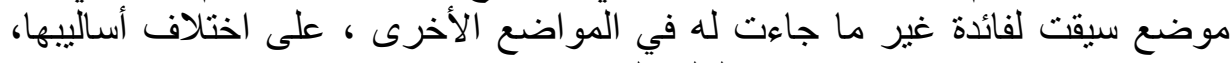

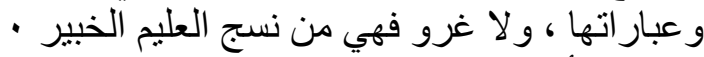

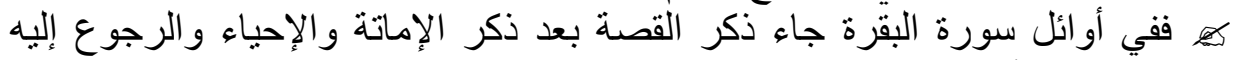

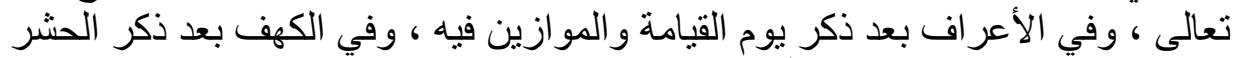

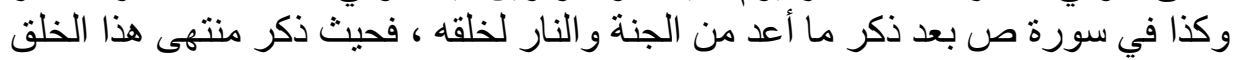

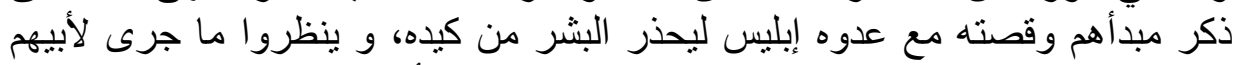

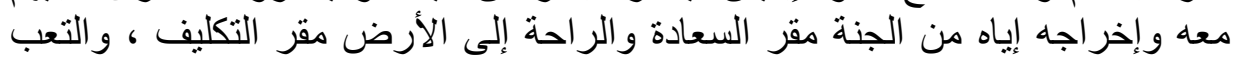

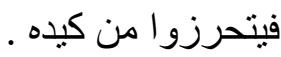

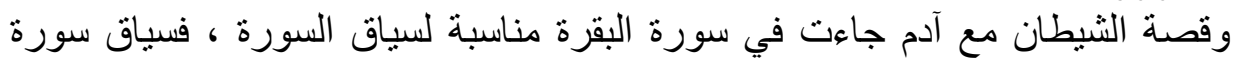

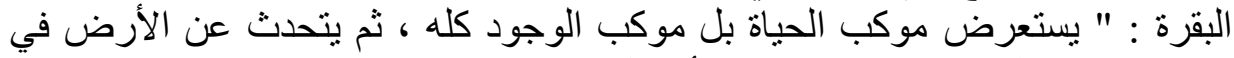

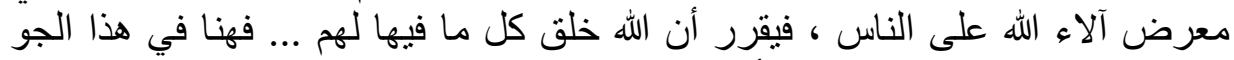

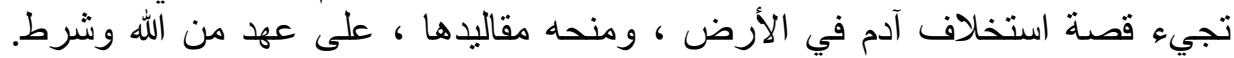

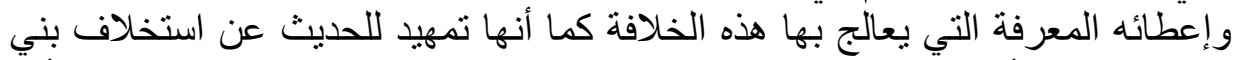

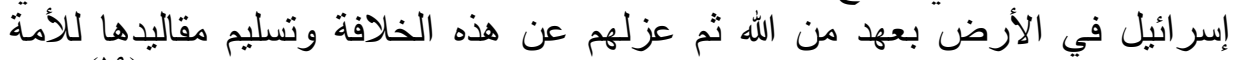

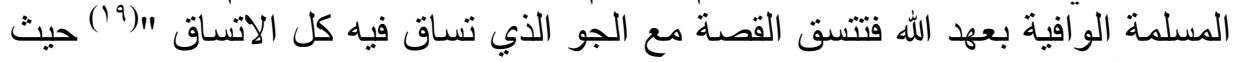

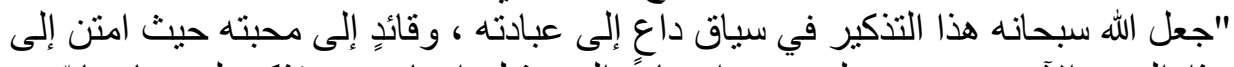

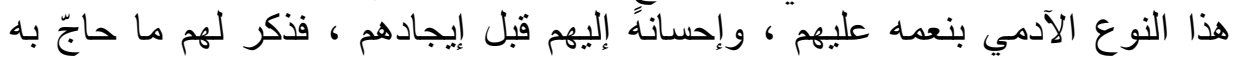

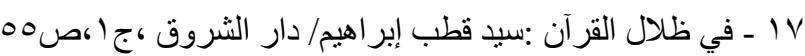

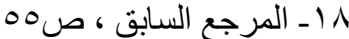

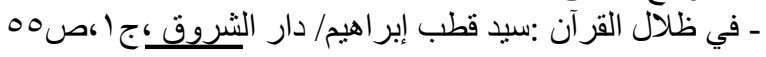




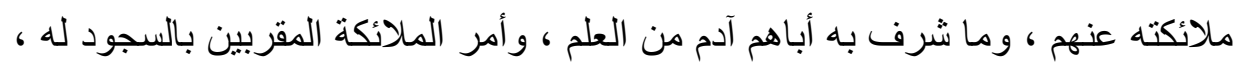

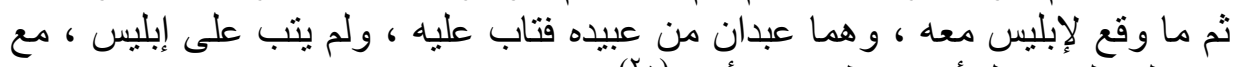

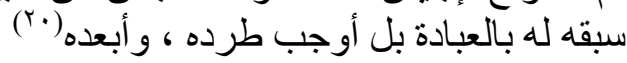
مناسبة هذه الآية لما قبلها : أن الله تعالى لما شرف آدر آدم بفضيلة العلم ، و و جعله معلما

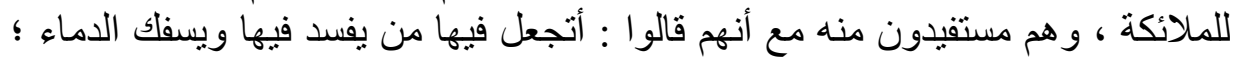

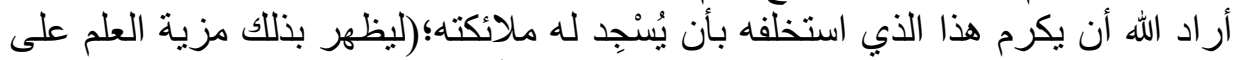

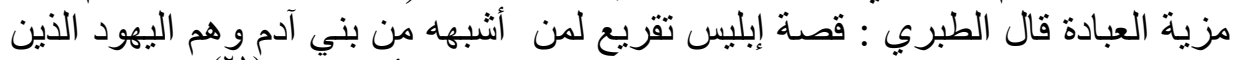

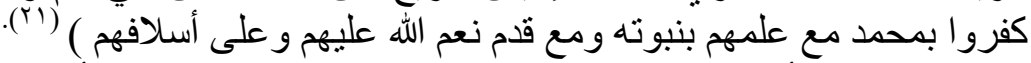

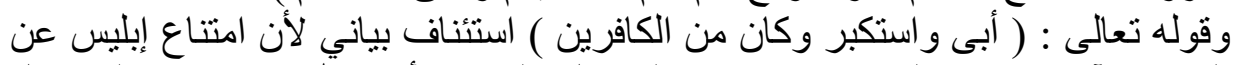

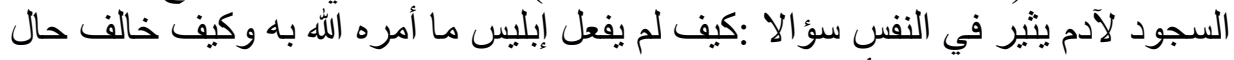
جماعته وما سبب ذلك لأن مخالفته لحالة الجماعة حالة شاذة إذ الذالة المعتاد المو افقة بين

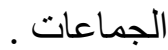
وأن اللهال لما شرف آدم برتبة العلم ، و بإِجاد الملائكة له امتن عليه بأن أسكنه

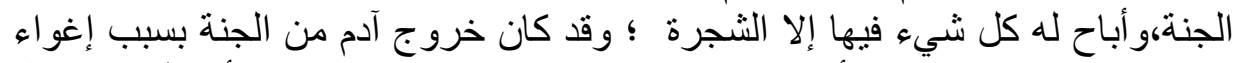

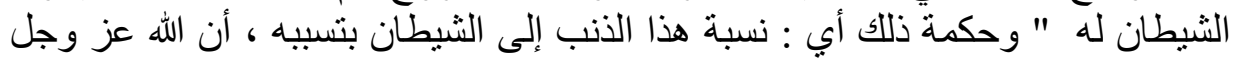

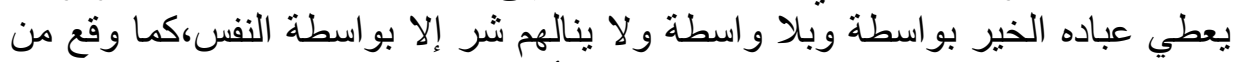

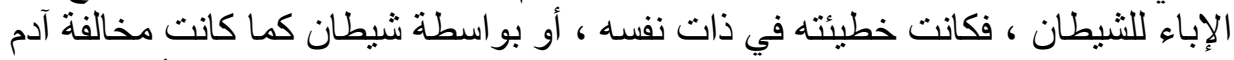

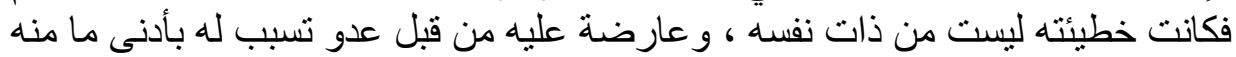

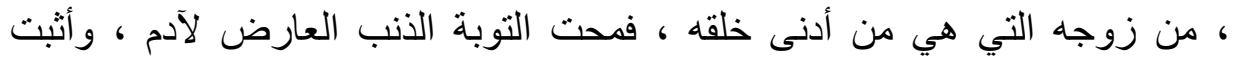

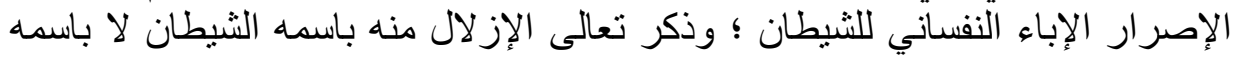

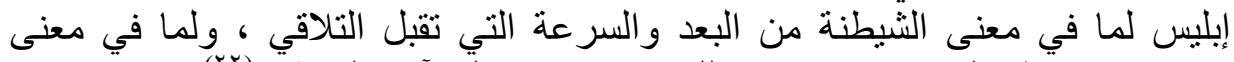

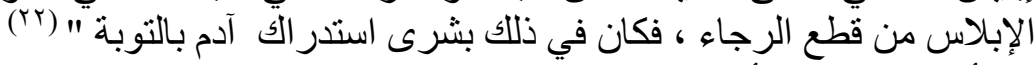

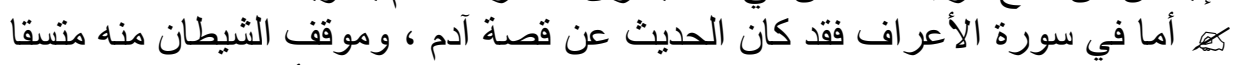

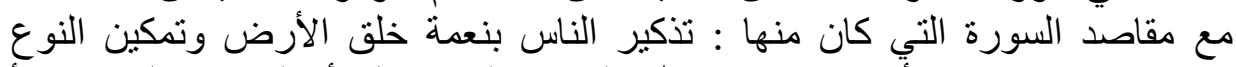

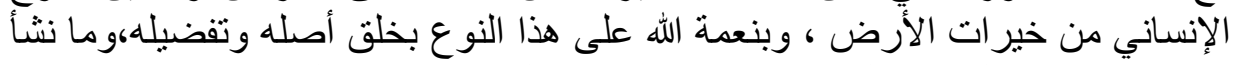

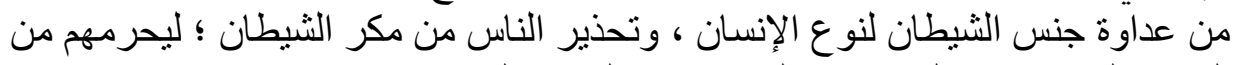

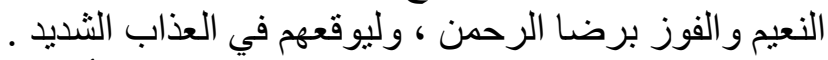

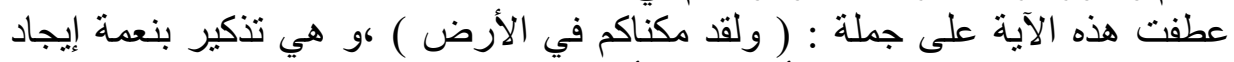

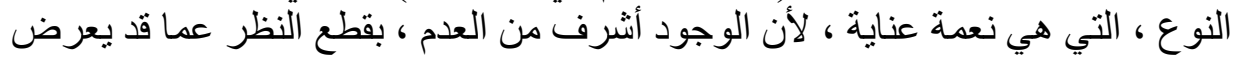

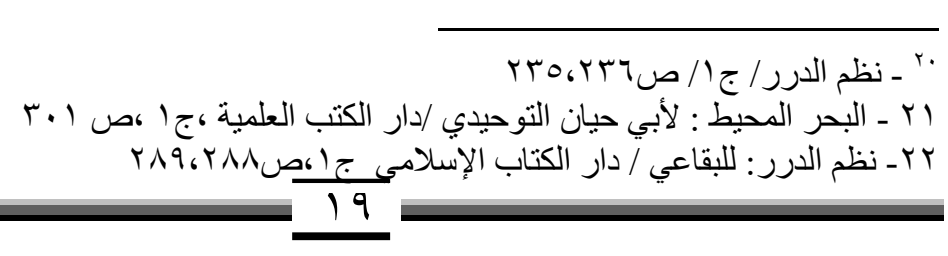


للموجود من الأكدار و المتاعب ، وبنعمة تفضيله على النوع حيث أمر الملائكة بالسجود

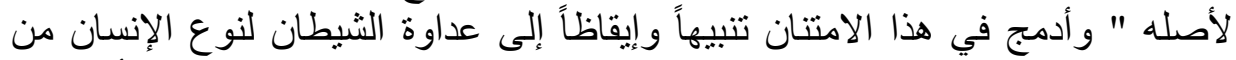

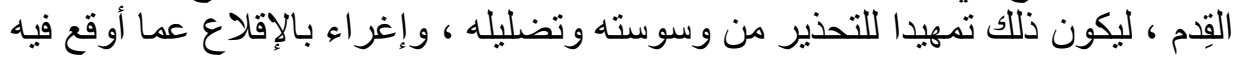

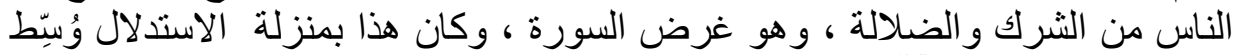

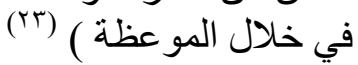

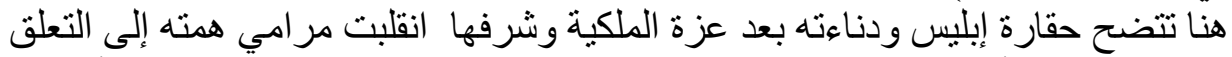

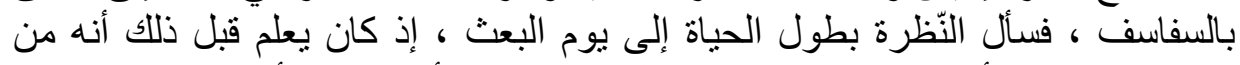

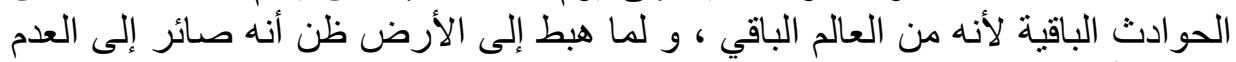

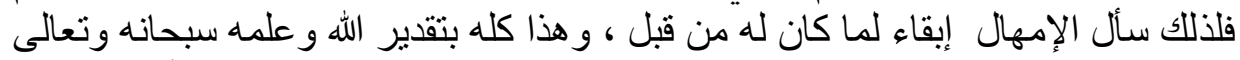

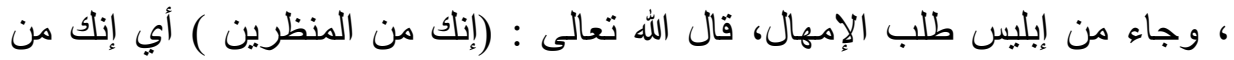

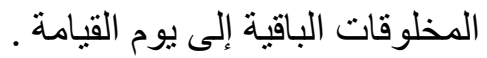

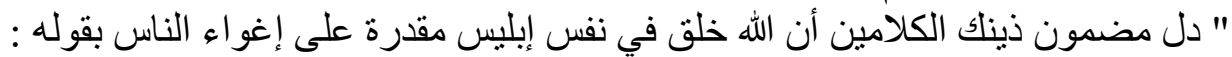

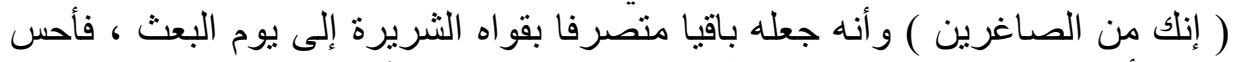

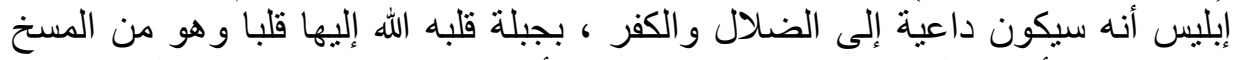

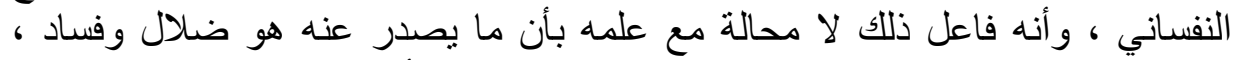

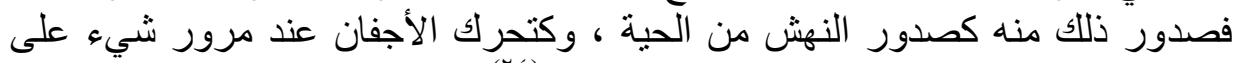

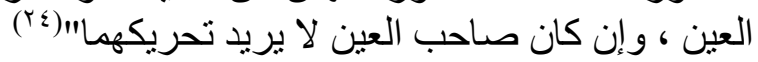

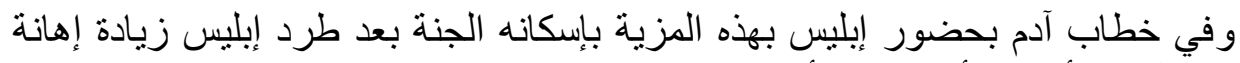

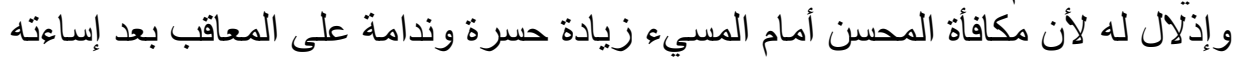

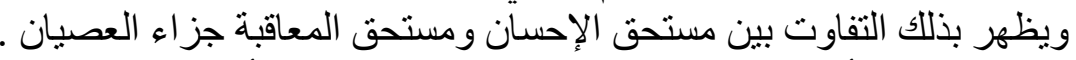

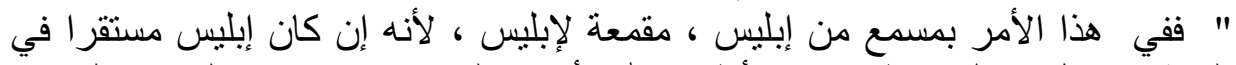

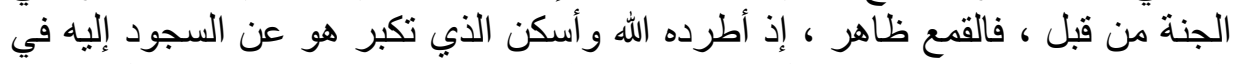

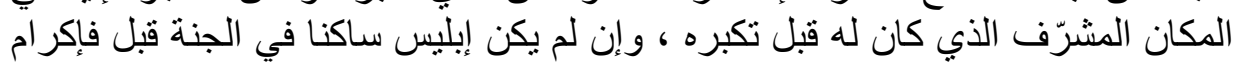

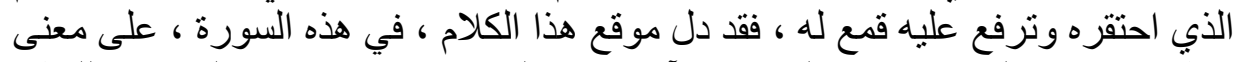

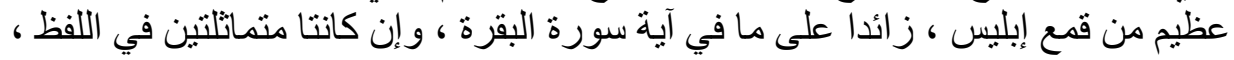

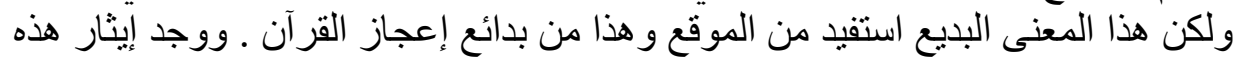

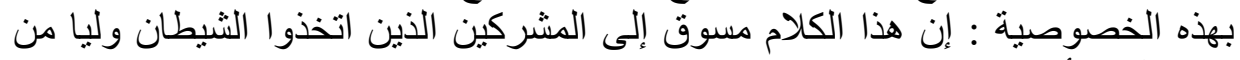

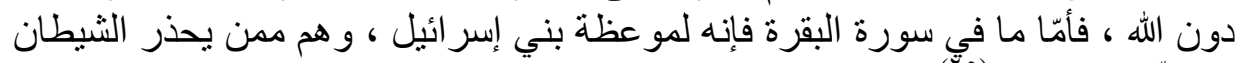

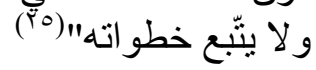

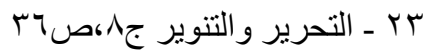

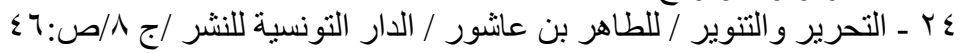

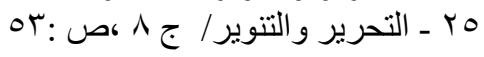




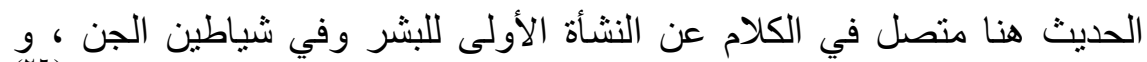

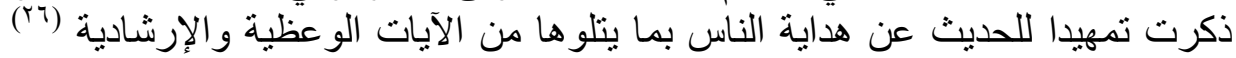

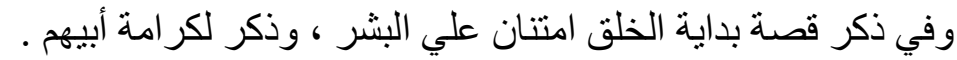
وذكر الله تعالى قصة آدم عليه السلام لييين لعباده ما جرت سنتهن فيهم من تسلط الثنيطان

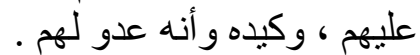

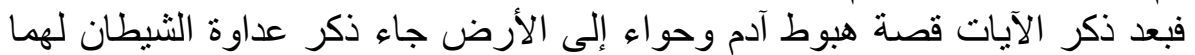

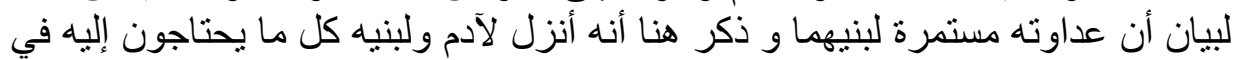

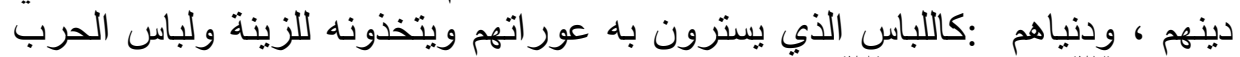

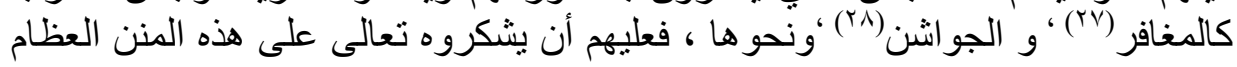

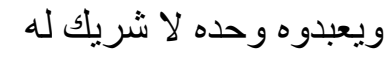

قصة آدم مع الثيطان في سورة الأعراف تختلف عما ذكر في سورة البقرة حيث الثيث

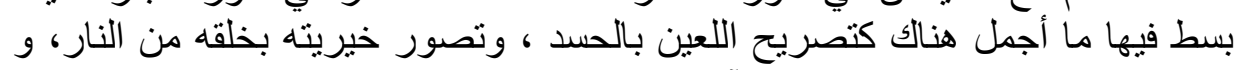

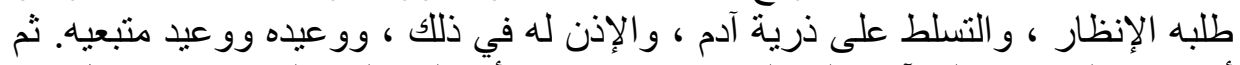
أخذه في الوسوسة إلى آدم عليه السلام : (وقاسمهما أني لكما لمن الناصحين الإن ) وكل هذا

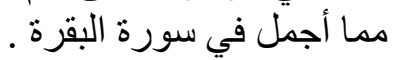

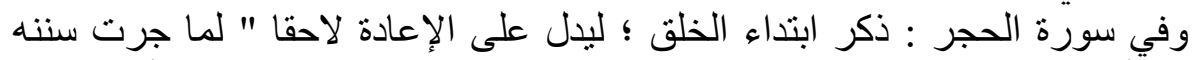

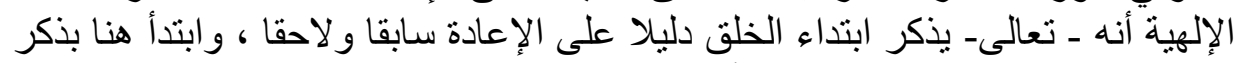

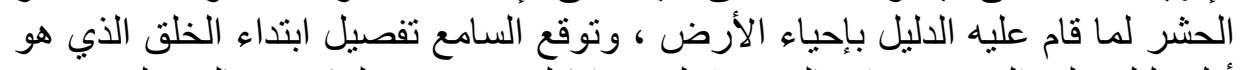

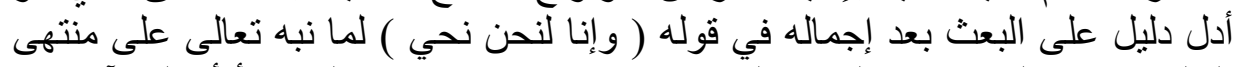

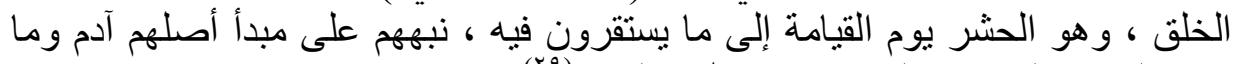

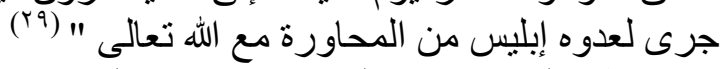

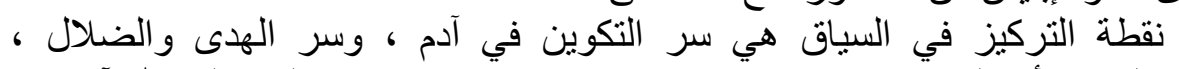

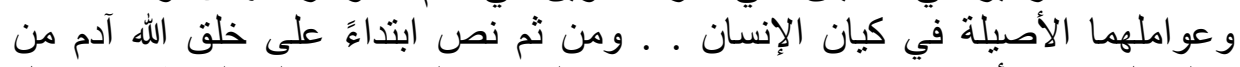

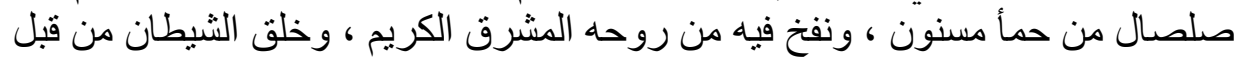
من نار السموم ـ ثم عرض حكاية سجود الملائكة وإباء إبليس استنكافا من السجود لبنشر

بr - ـ وذلك في الآيات التي تليها من قوله تعالى : ( و إذا فعلو ا فاحشة قالو ا وجدنا عليها آباءنا و الله أمرنا

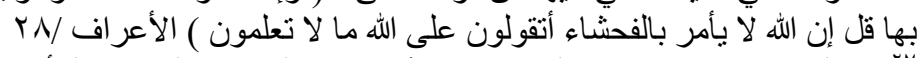

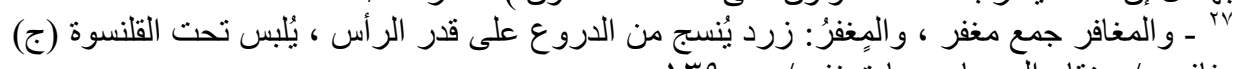

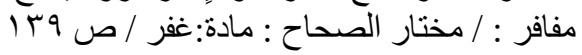

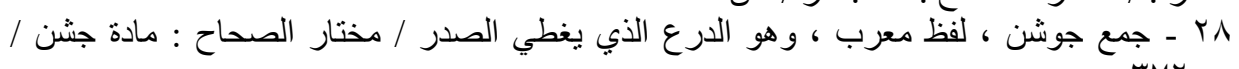

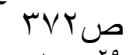

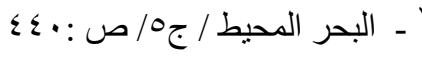


من صلصال من حمأ مسنون ، وطرده ولعنته ، وطلبه الإنظار إلى يوم البعث و إجابته،

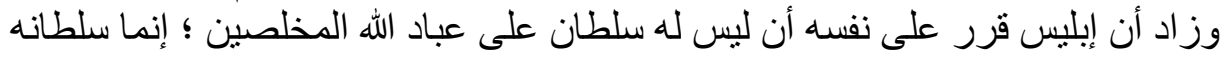

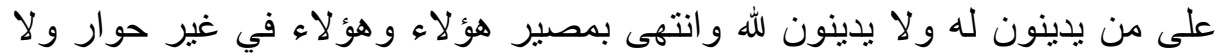

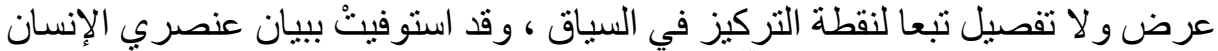

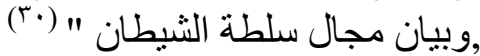

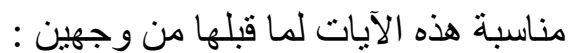

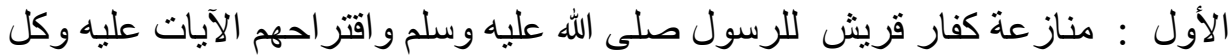

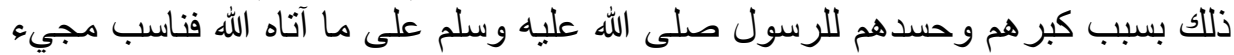
قصة آدم في هذا السياق لأن ما حمله على العصيان والامتناع من السجود إنما هو الكبر ملاه و والحسد آن في

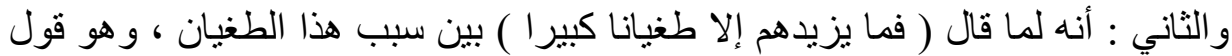

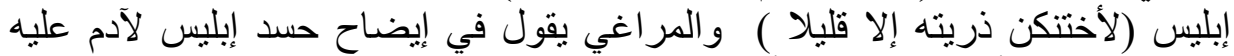

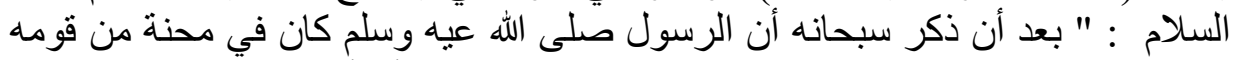

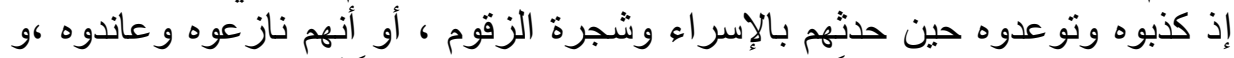

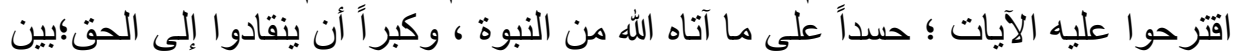

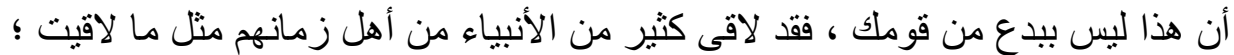

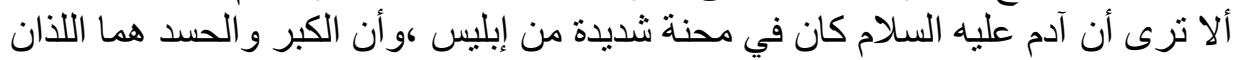
حملاه على الخروج من الإيمان والديه الدخول في الكفر ؛والحسد إلئ بلية قديمة ومحنة عظيمة

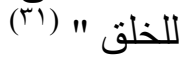

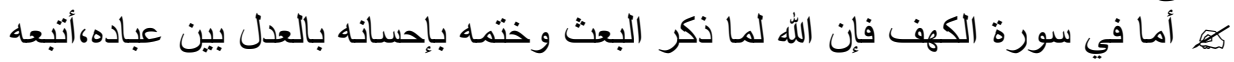

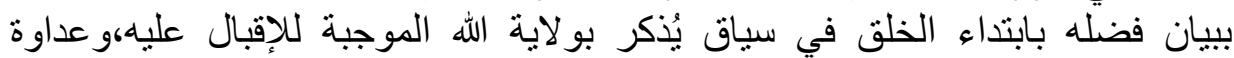

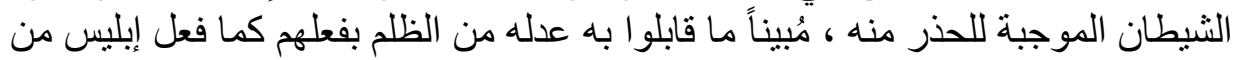

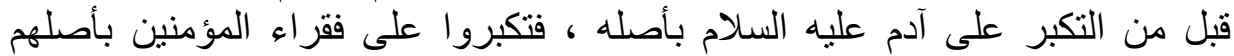

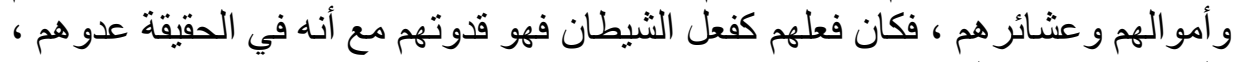

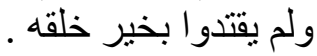

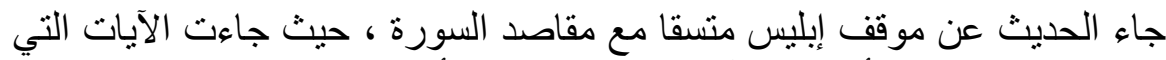

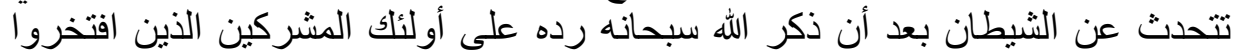

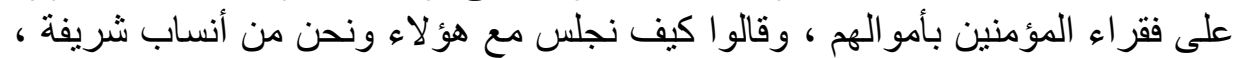

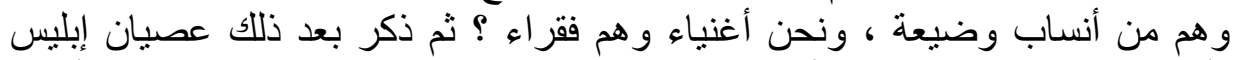

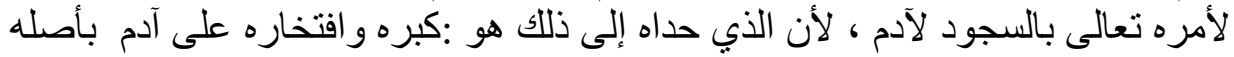

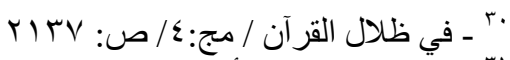

ـ تفسير المر اغي /لأحمد مصطفى المر اغي / شركة مكتبة ومطبعة البابلي الحلبي: ج 0 ا،صوب79 


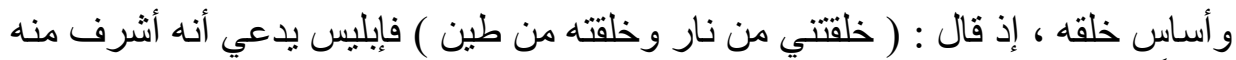

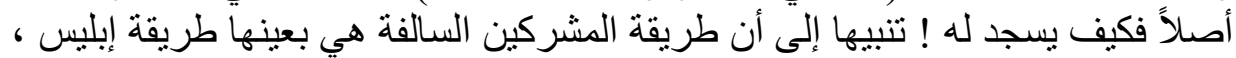

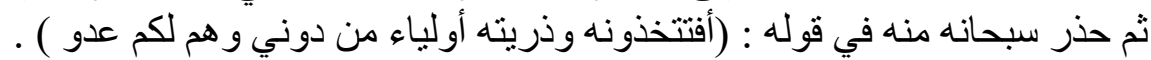

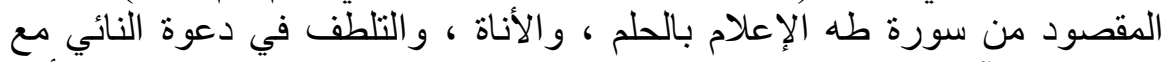

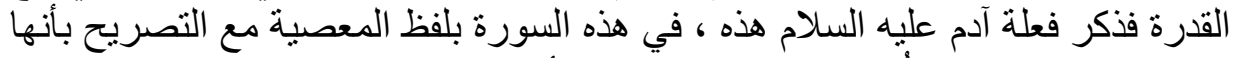

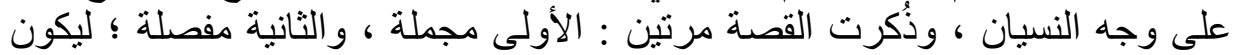

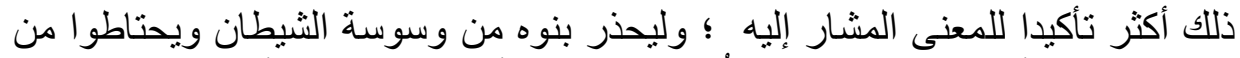

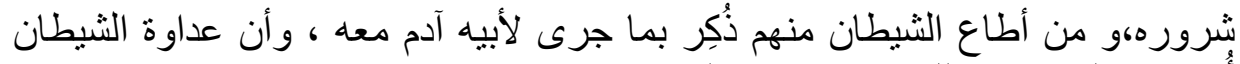

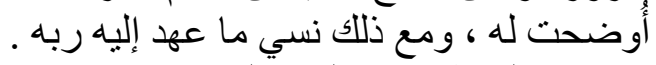

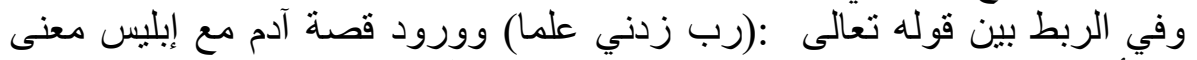

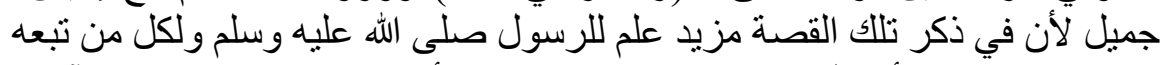

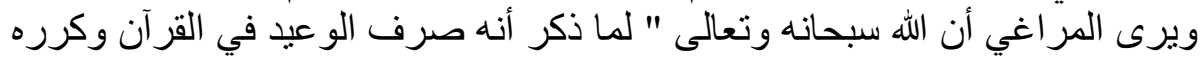

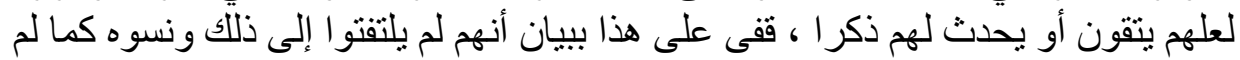

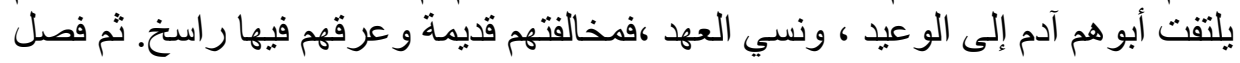

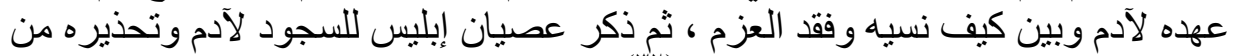

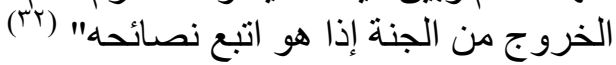

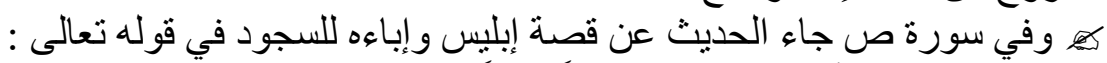

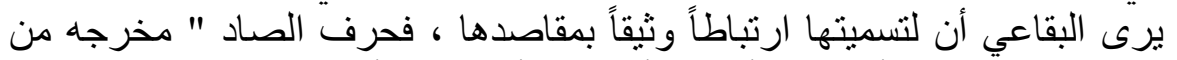

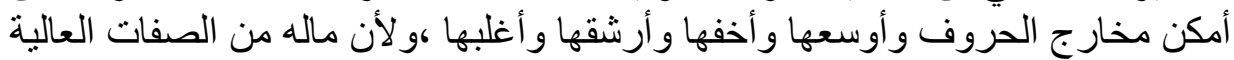

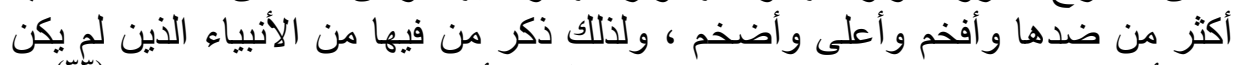

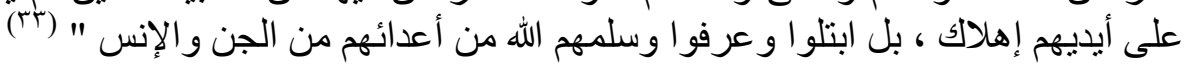

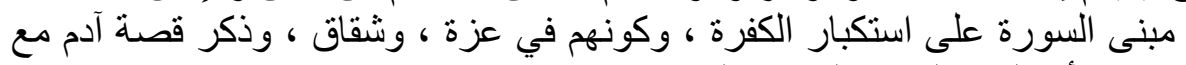

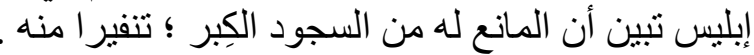

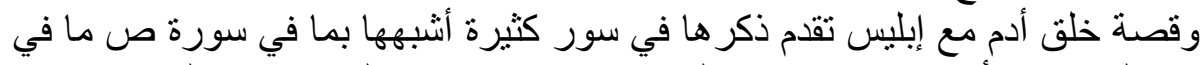
سورة الحجر ، وأبينها ما في سورة البقرة الباع ووقع في سورة الحجر (إلا إبليس استكبر)

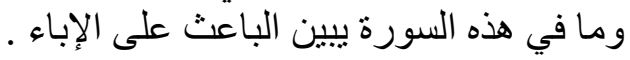

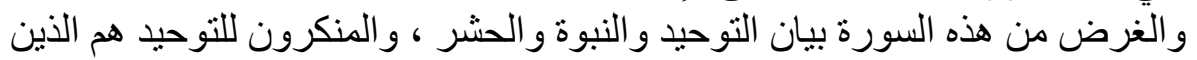

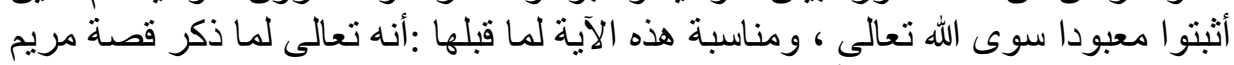

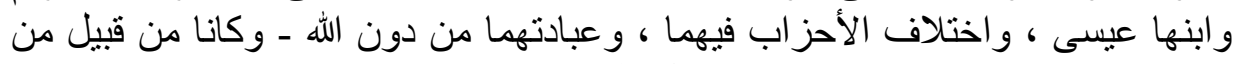

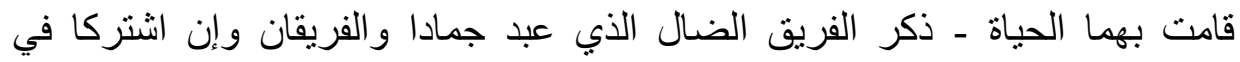

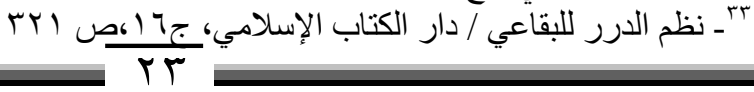


الضلال ، فالفريق العابد الجماد أضل ، ثم ذكر قصة إبر اهيم مع أبيه عليه السلام تذكيرا

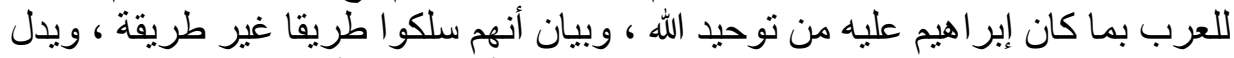

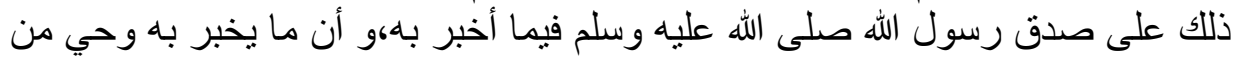

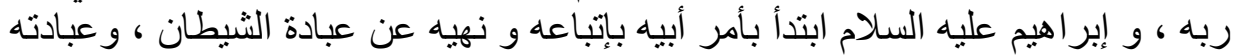

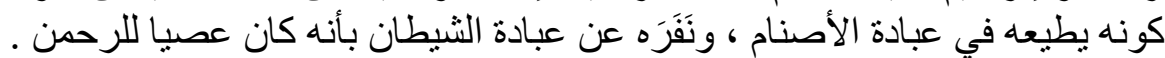

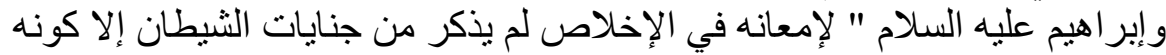

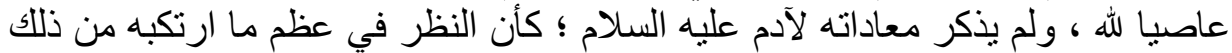

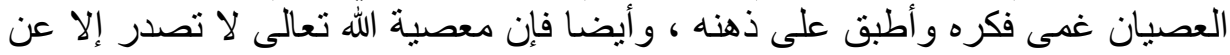

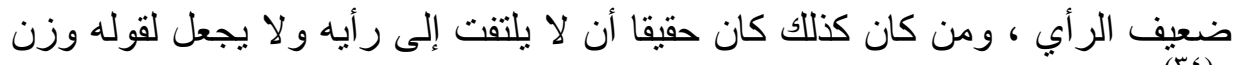

$(\Gamma \leq)_{1 \prime}$

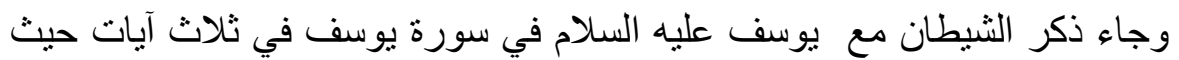

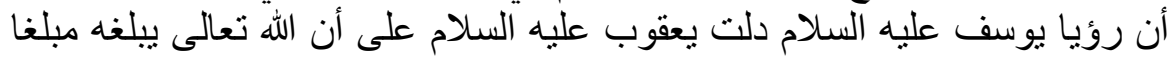

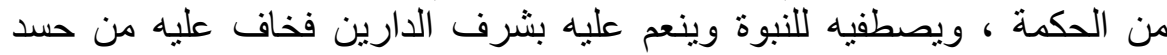

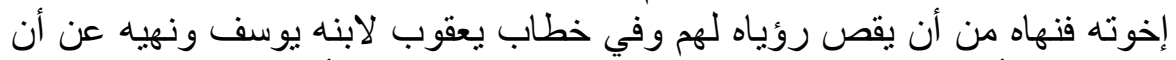
يقص على أخوته مخافة كيدهم ؛ دلاهلة فئه على تحذير المسلم أخاه المسلم ممن يخافه

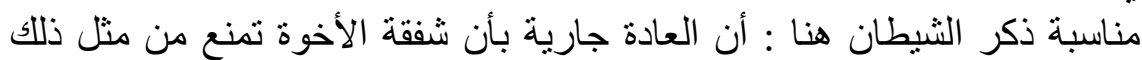

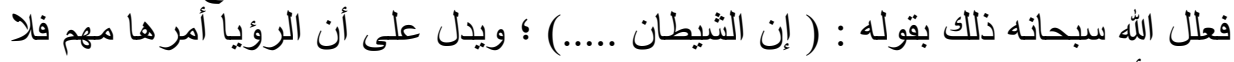

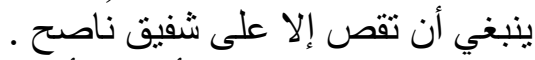
"و السبب في هذا الكلام أنهم لو أقدمو إعلى على الكيد لكان ذلك مضافا إلى الثيطان ونظيره

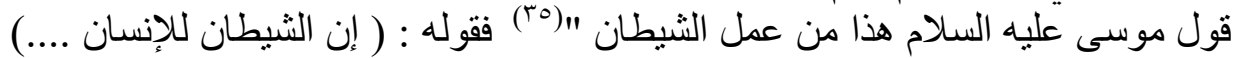

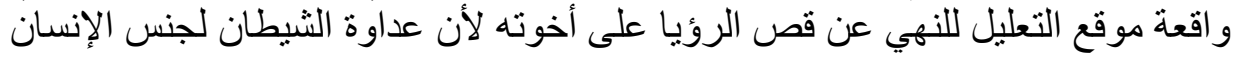

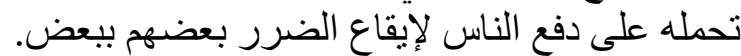

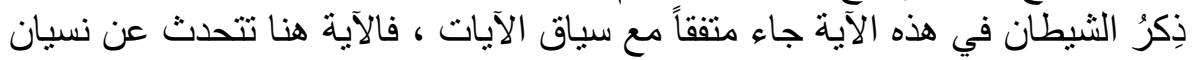

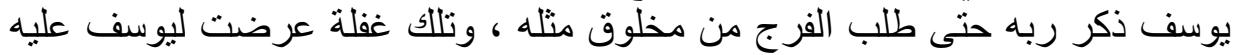

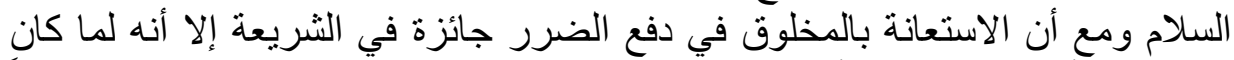

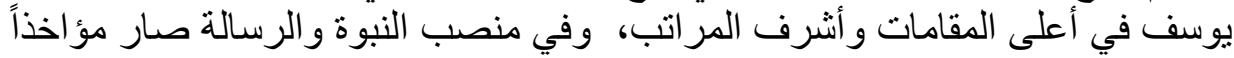

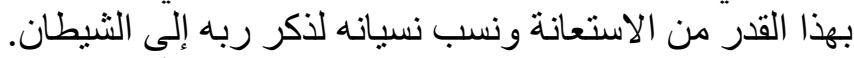

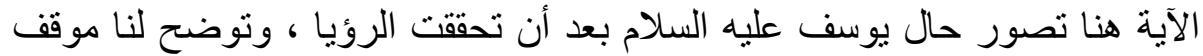

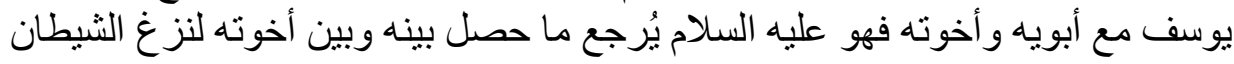




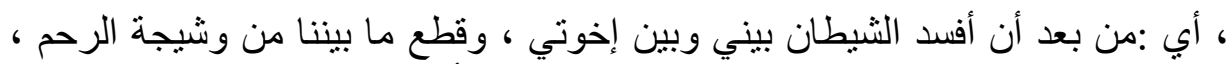

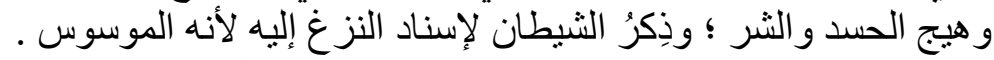

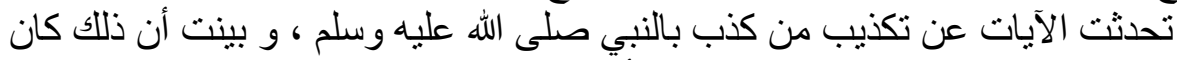

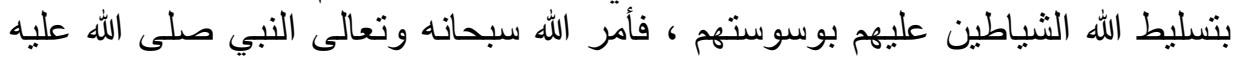

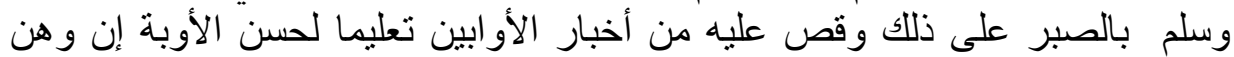

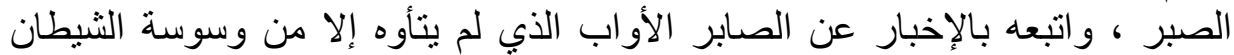

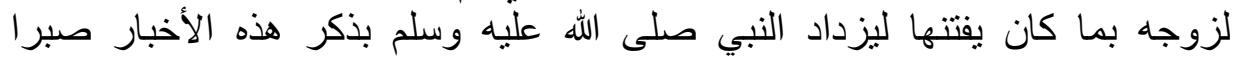

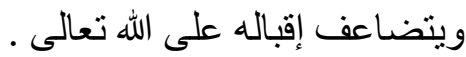

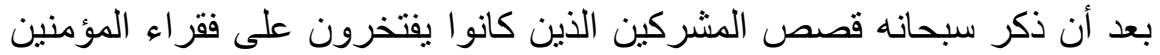

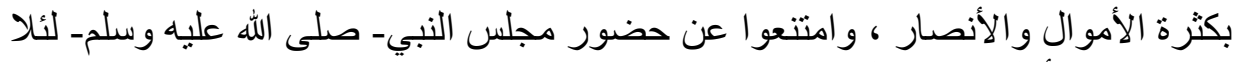

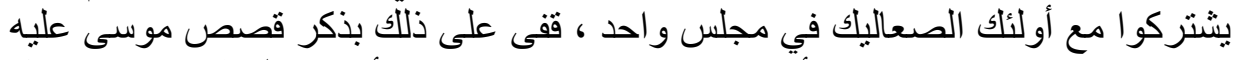

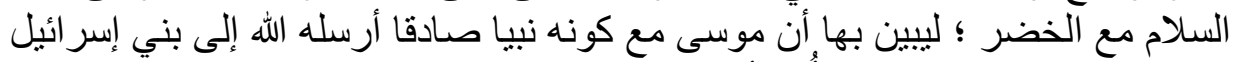

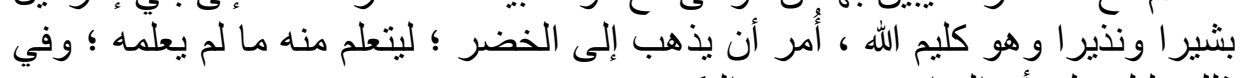

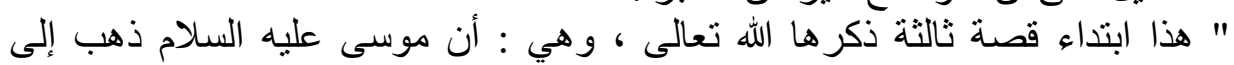

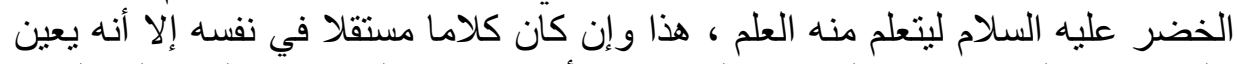

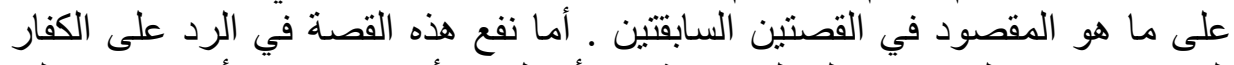

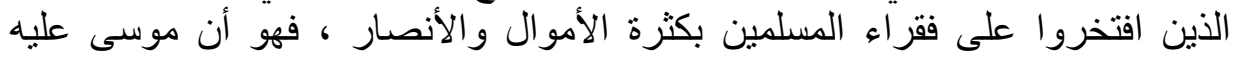

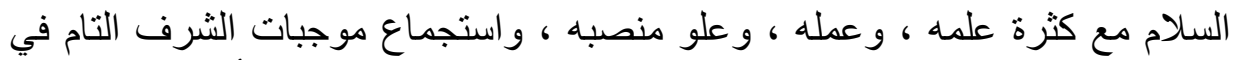

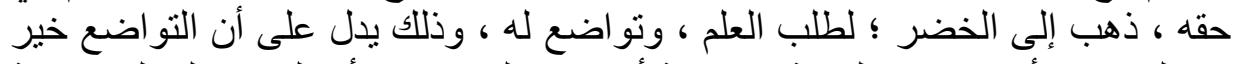

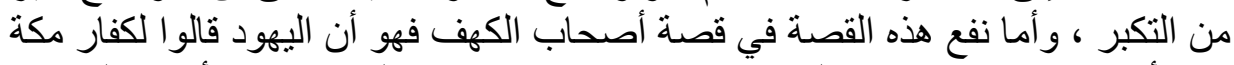

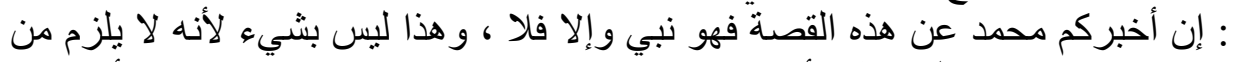

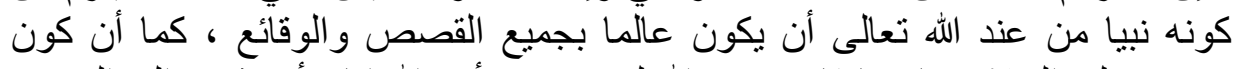

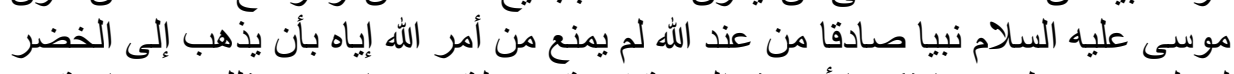

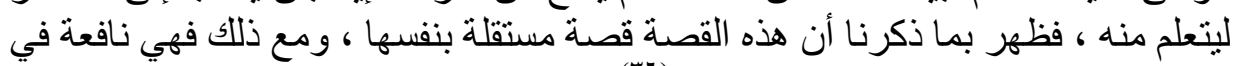

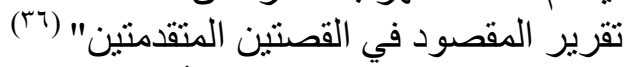

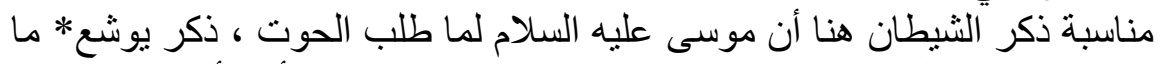

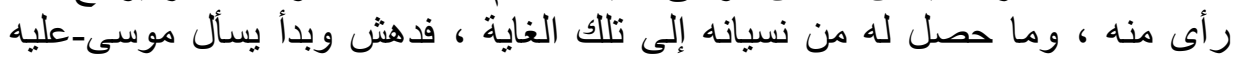

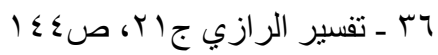
* هو يوشع بن نون و إنما قيل : فتاه ؛ لأنه كان يخدمه ويتبعه ، وقيل كان يأخذ منه العلم الكثاف جr

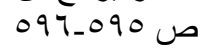


السلام - عن سبب ذللك ، كأنه قال : أر أيت ماذا دهاني إذ أوينا إلى الصخرة؛ فإني نسيت

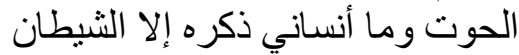

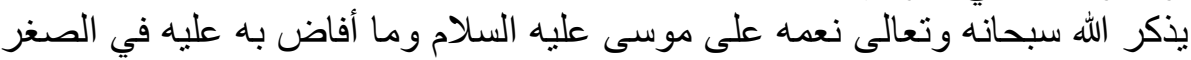

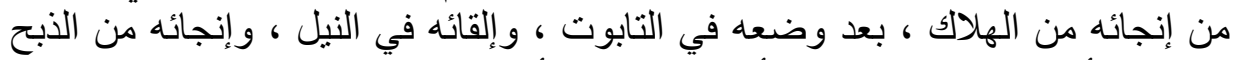

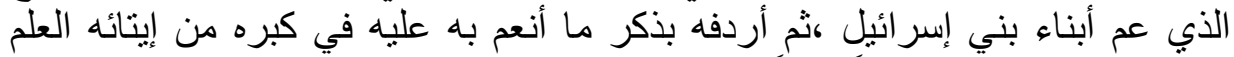

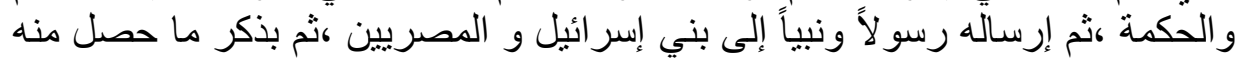

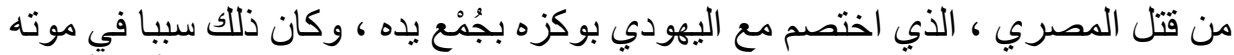

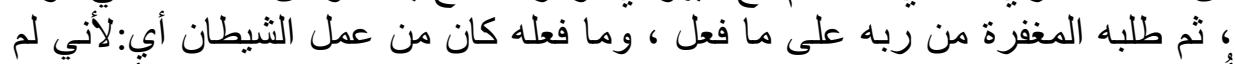

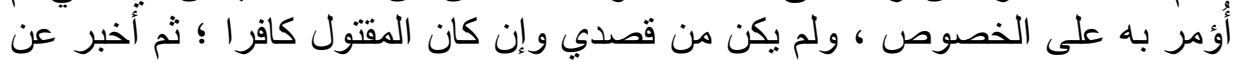

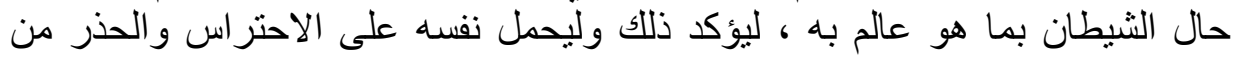
يبين سبحانه في هذه الآيات حالاً من أحو ال الكفار ، من جحود ، و وعناد، ومعاداة

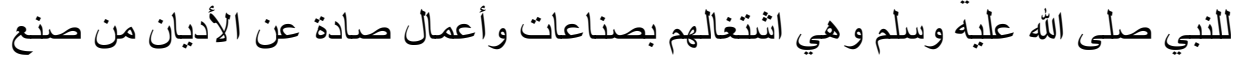

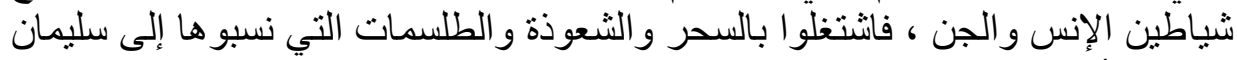

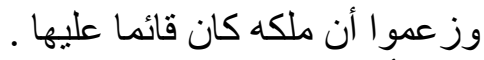

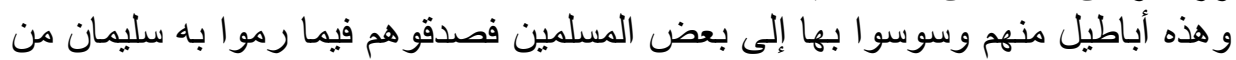

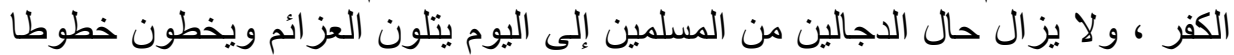

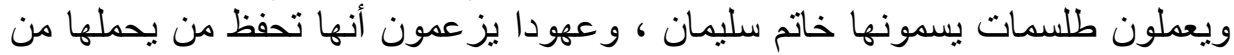

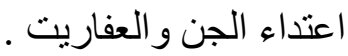

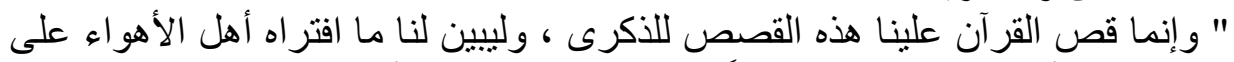

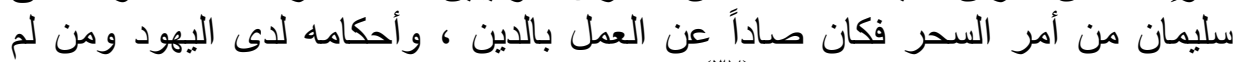

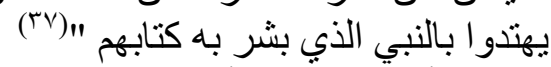
بعد أن ذكر الله ما أنعم به بله بلى نوح عليه عليه السلام من النعم الجليلة قفى على ذللك بذكر

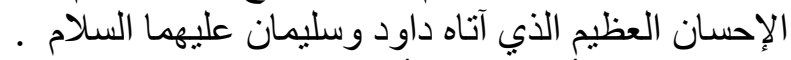

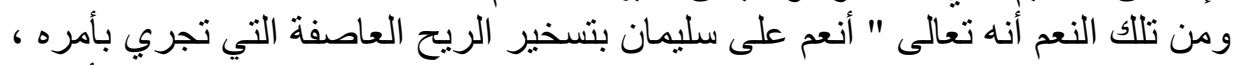

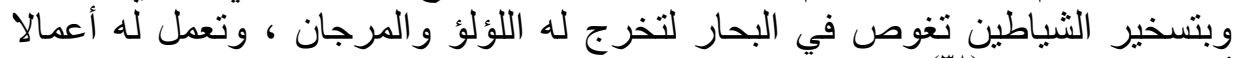

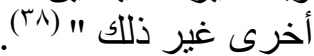

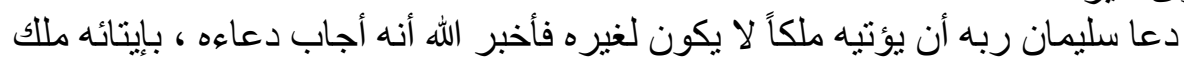

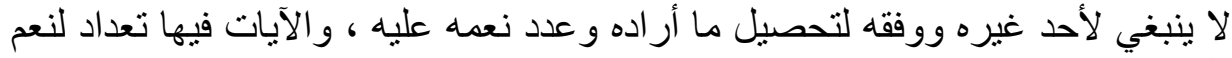
الله على نبيه سليمان عليه السلام. 


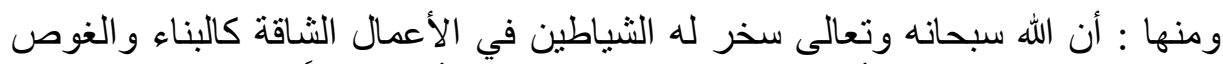

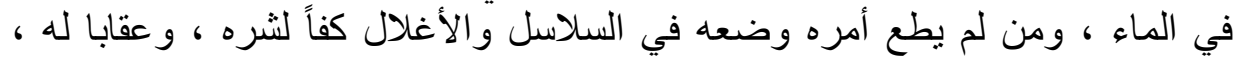
و عبرة لغيره . كهُ وفي قصة الهادهد مع سليمان جاء ذكر الثنيطان حين أر اد الهدد الاعتذار إلى سليمان

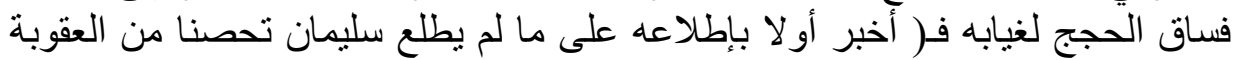

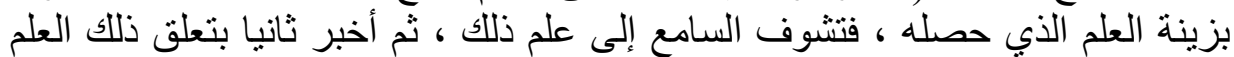

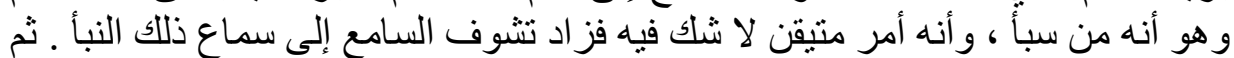

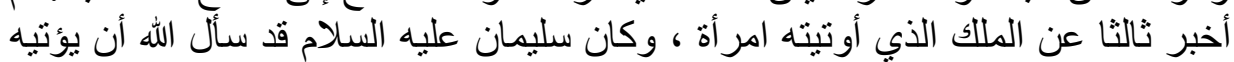

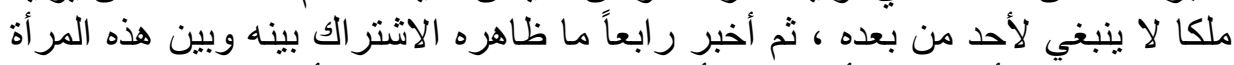

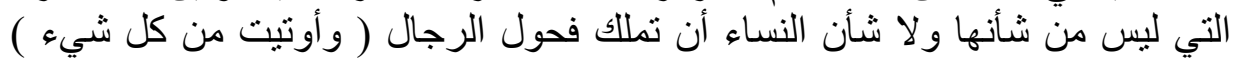

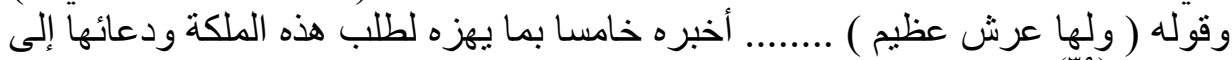

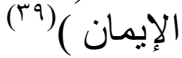

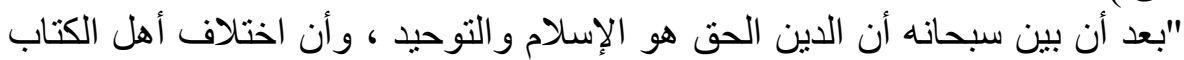

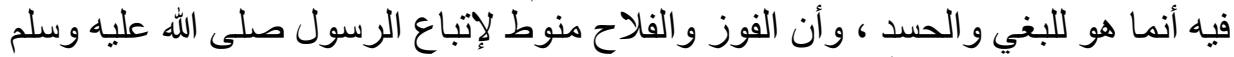

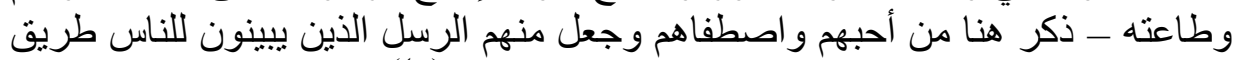

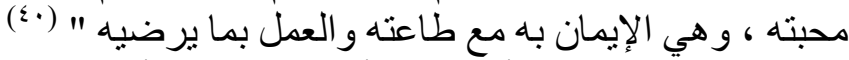

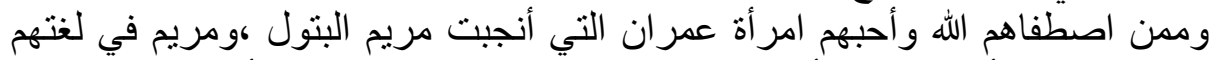

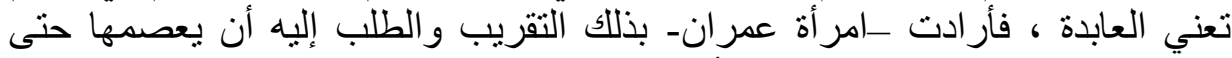

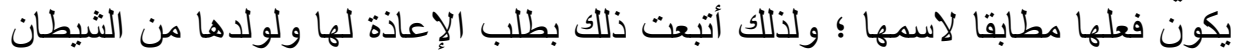
و إغوائه .

\section{الشيطان في قصص الأمم السابقة : الهابه}

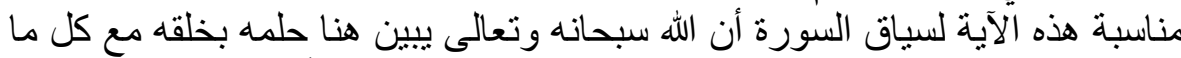

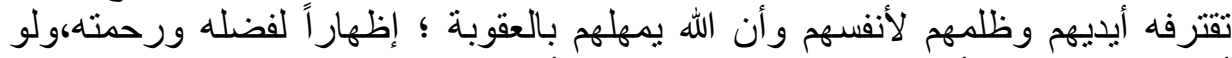

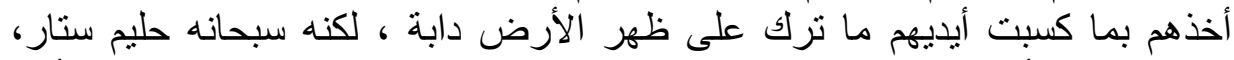

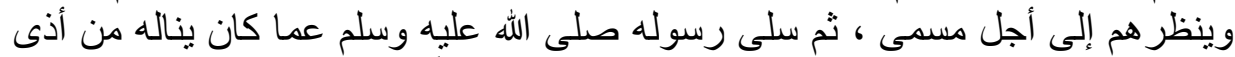

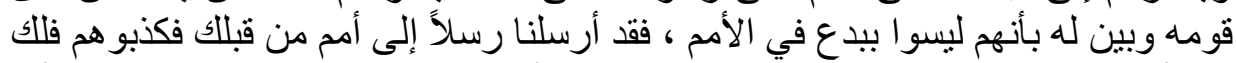

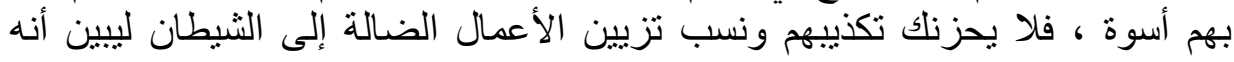

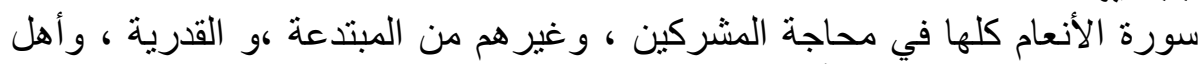

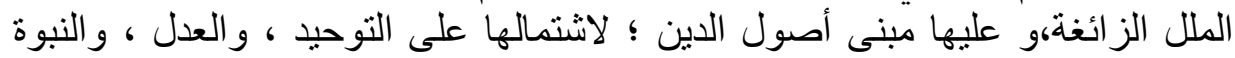




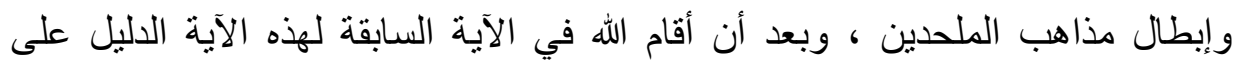

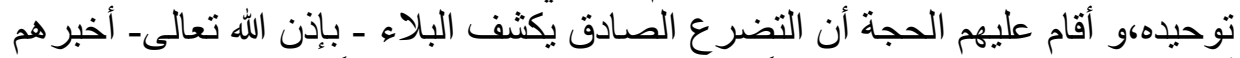

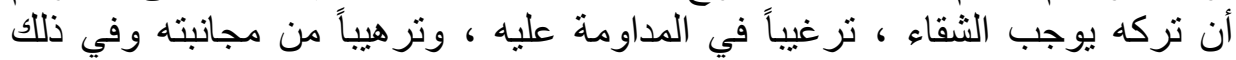

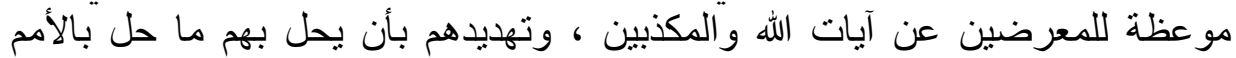

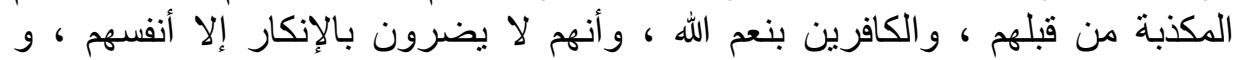

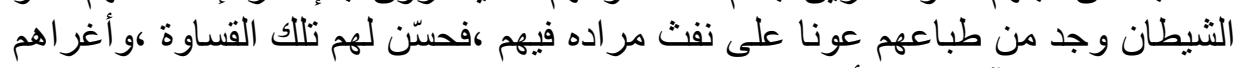

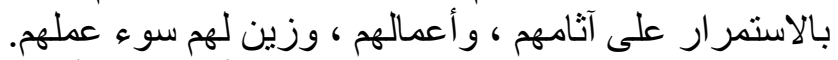

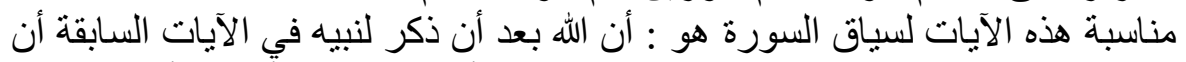

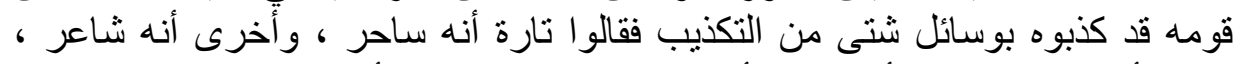

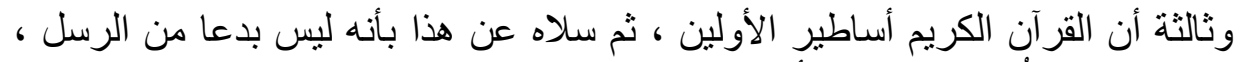

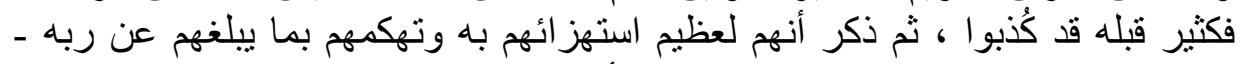

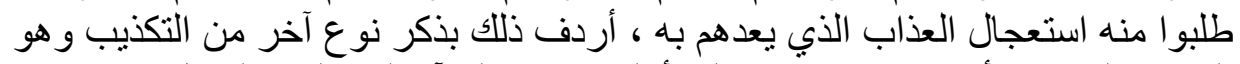

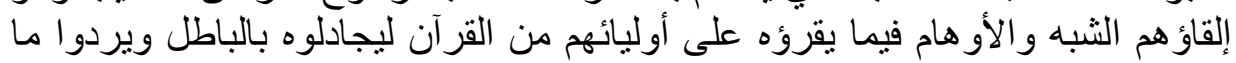

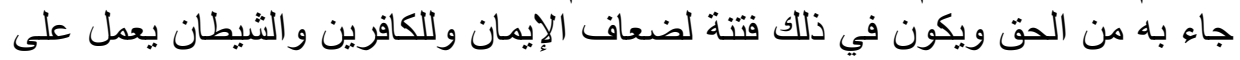

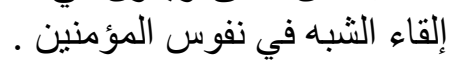

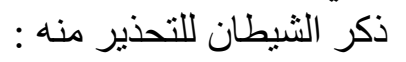

وجاء ذكر الثيطان في القرآن الكريم للتحذير من إنباعه ولكن التبان الخطاب القرآني لا

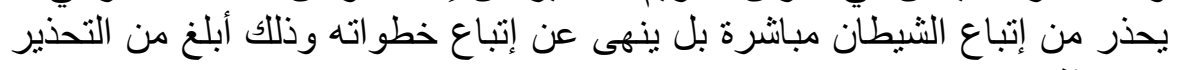

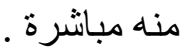
هذه الآية جاءت متفقة مع نسق بناء السورة بما يحقق التناسق التام في السورة

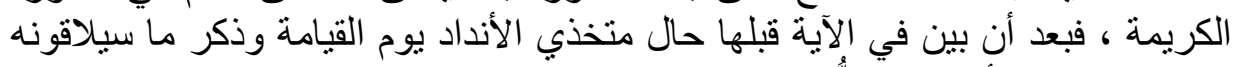

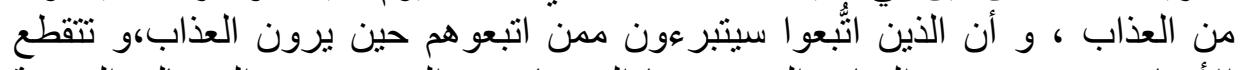

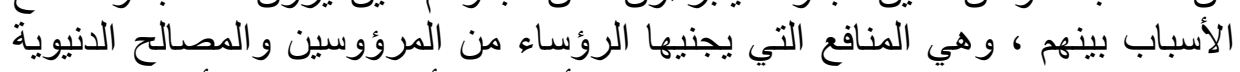

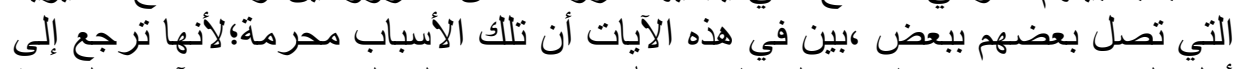

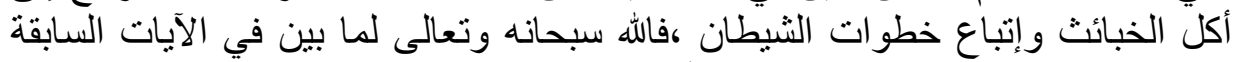

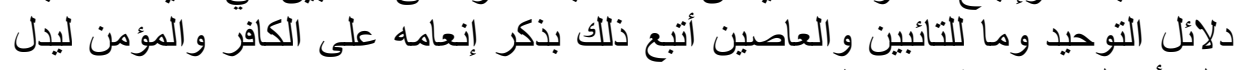

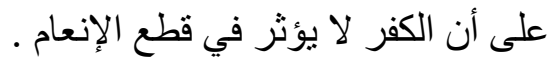

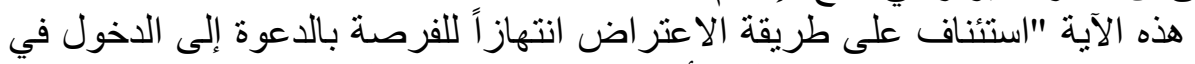

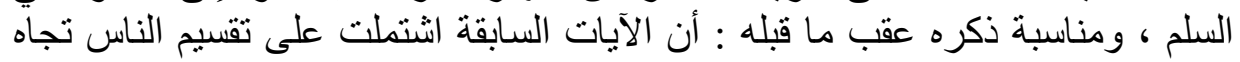

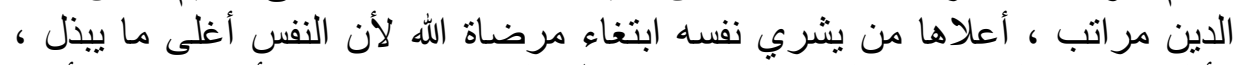

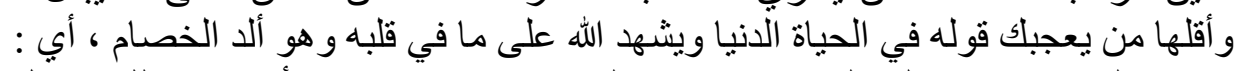

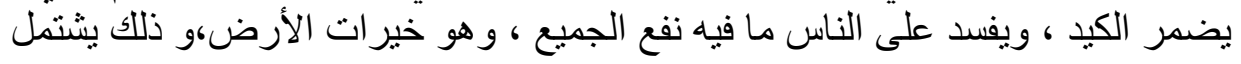


على أنه اعتدى على قوم مسالمين ، فناسب بعد ذلك أن يدعي الناس إلى الدخول فيما

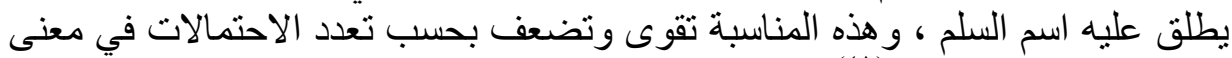

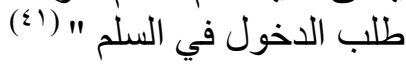

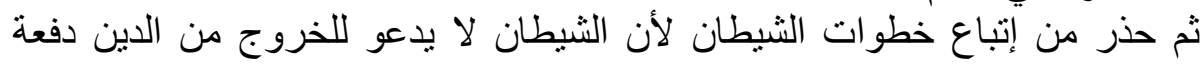

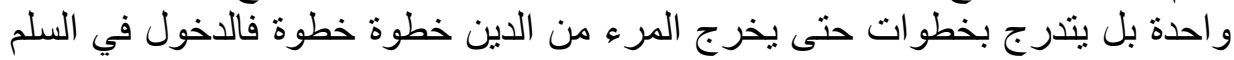

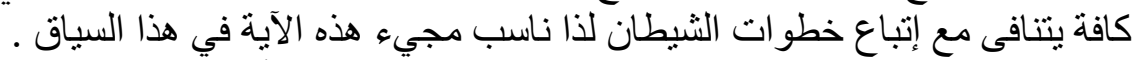

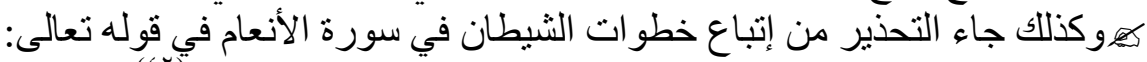

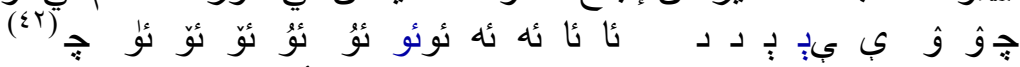

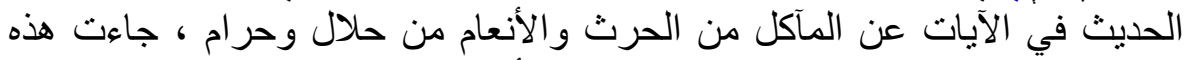

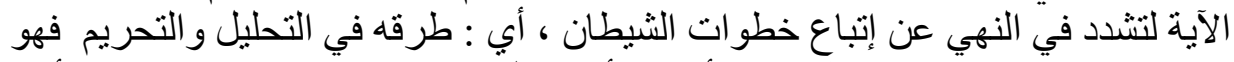

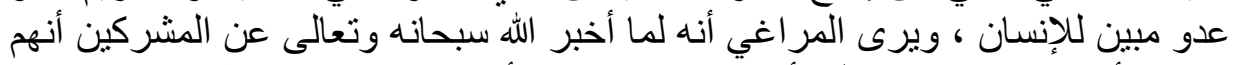

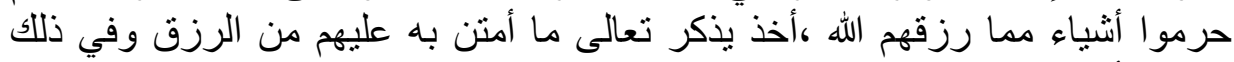

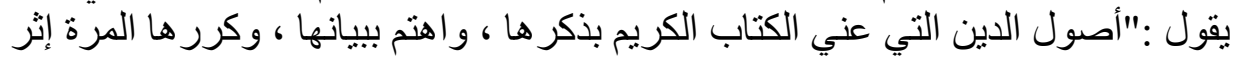

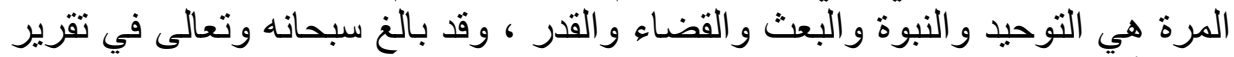

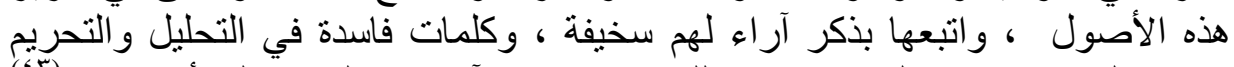

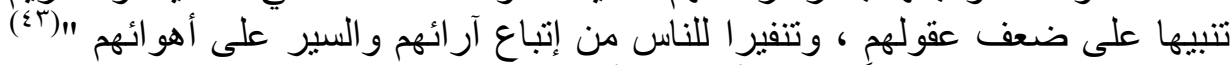

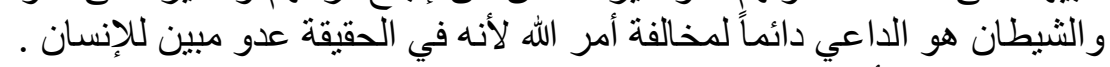

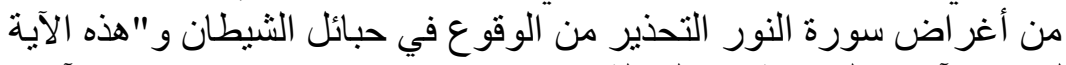

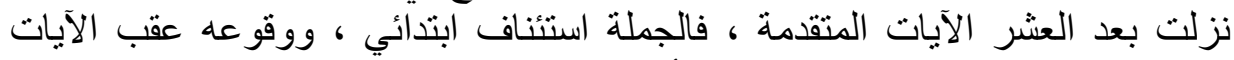

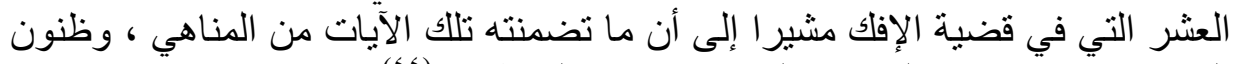

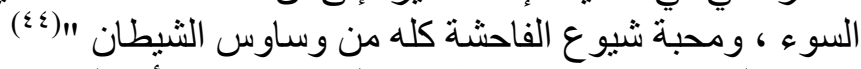

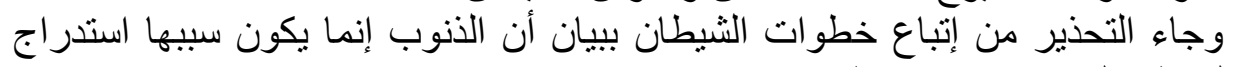

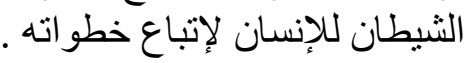

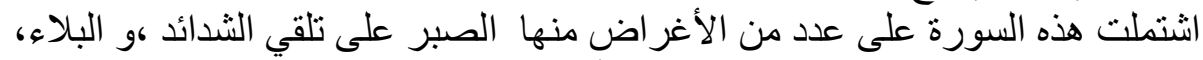

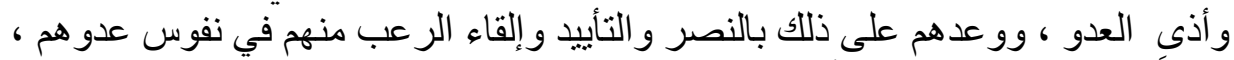

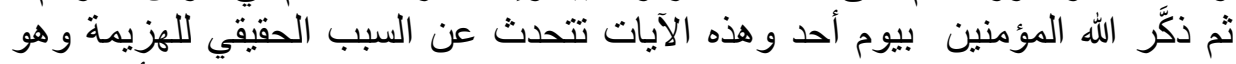

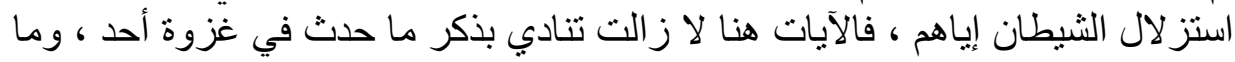

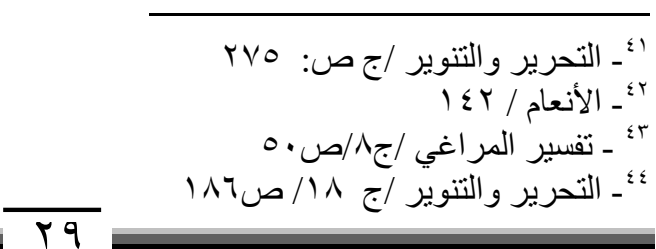


فيها من العظات والعبر ومن ذلك حصول الضرر لهم بما وقع من بعضهم من الخلل

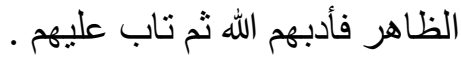

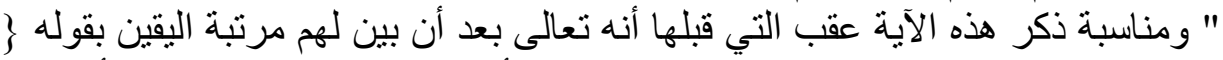

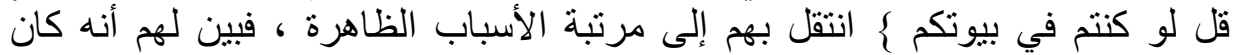

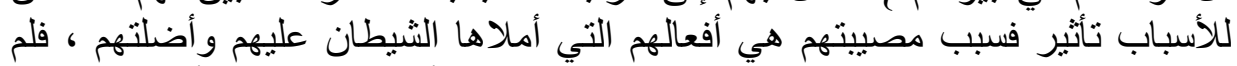

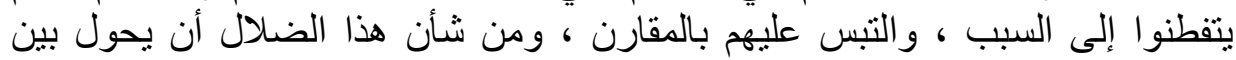

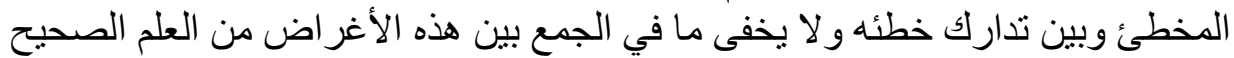

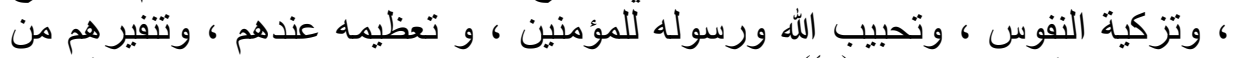

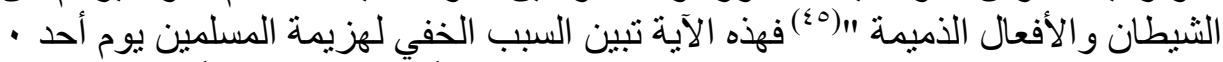

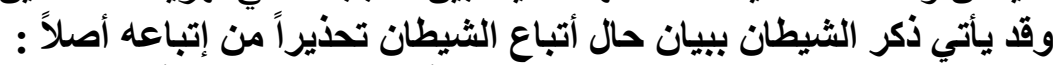

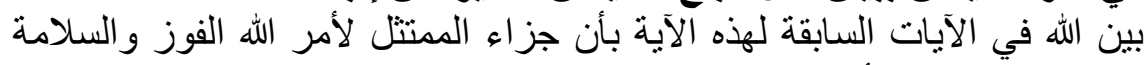

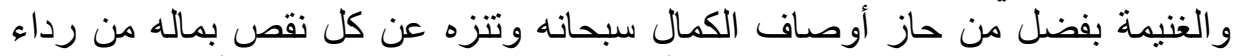

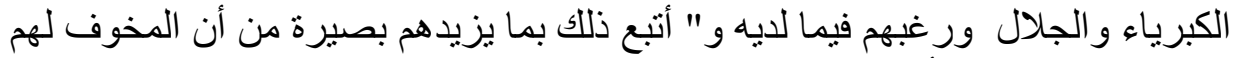

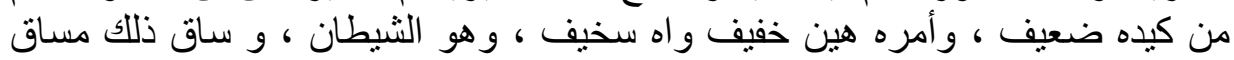

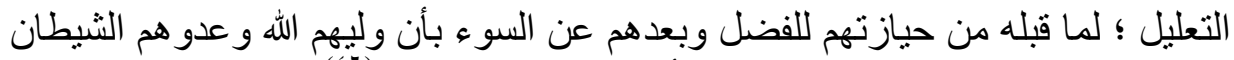

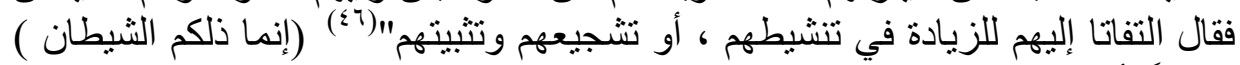

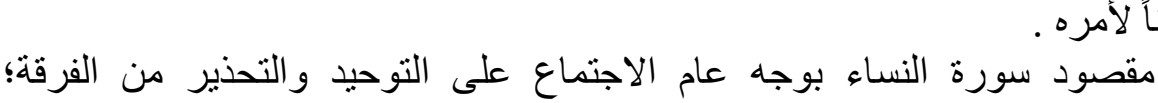

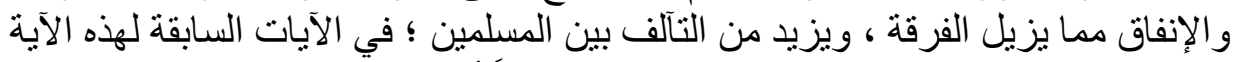

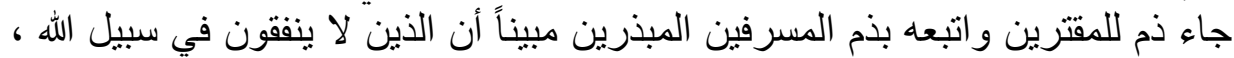

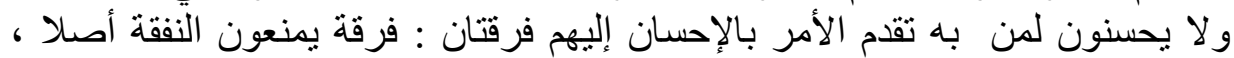

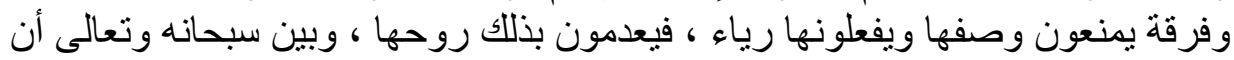

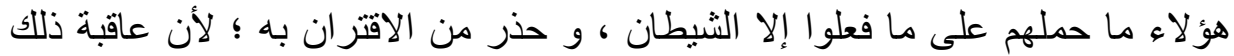

$$
\begin{aligned}
& \text { سيئة في الدنيا والآخرة . } \\
& \text { الفصل الثاني } \\
& \text { المبحث الأول }
\end{aligned}
$$

المشتقات وصيغ الأفعال ودلالاتها البلاغية

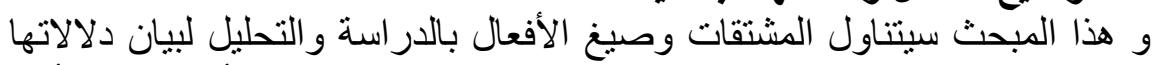

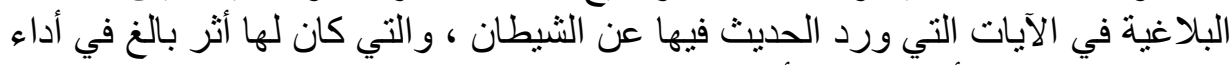

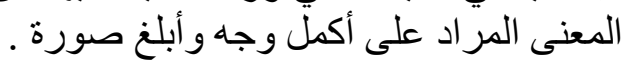


و لا عجب :"أن يتأنق أسلوب القرآن في اختيار ألفاظه ، و لما بين الألفاظ من فروق

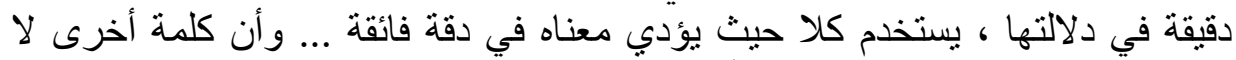

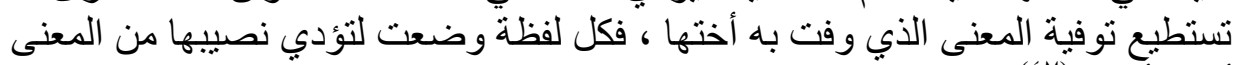

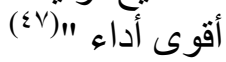

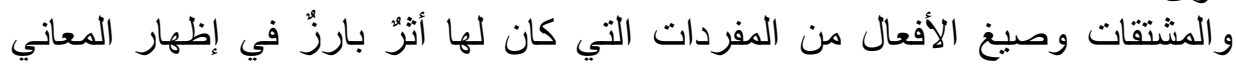

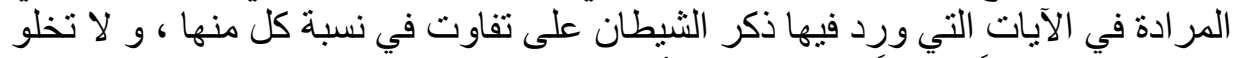

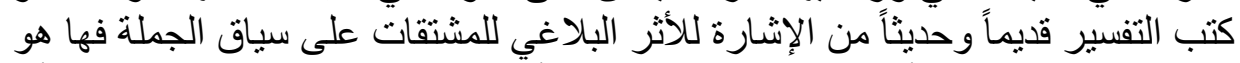

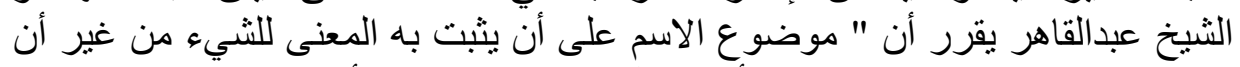

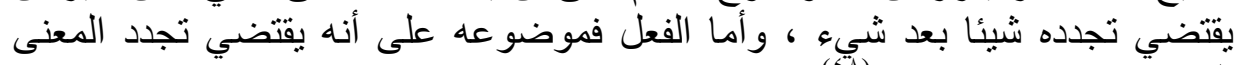

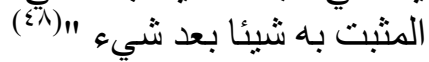

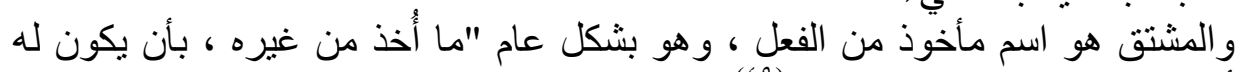

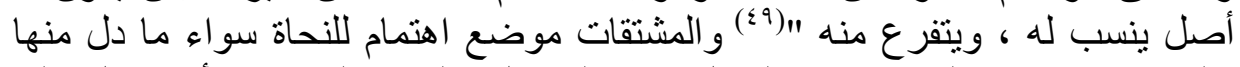

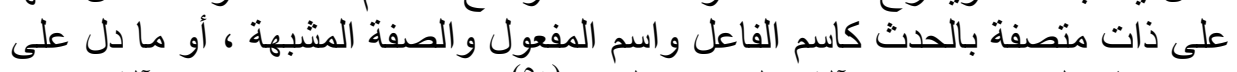

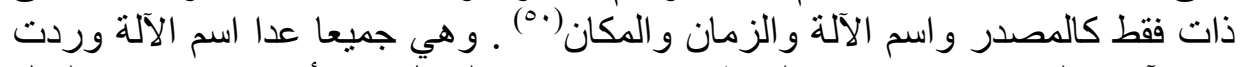

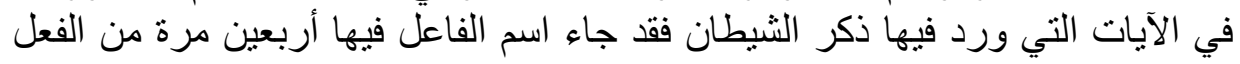

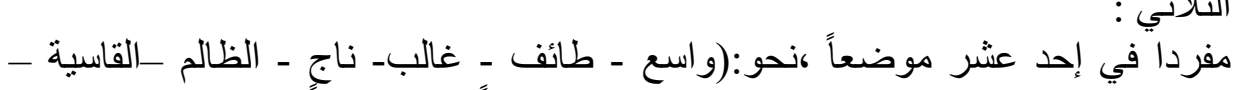

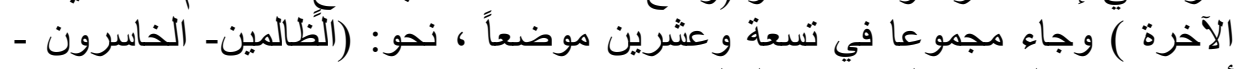

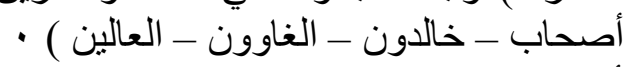

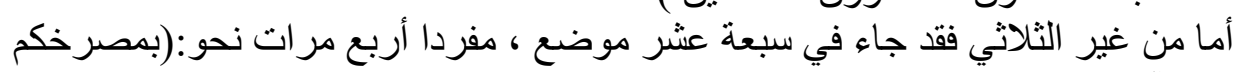

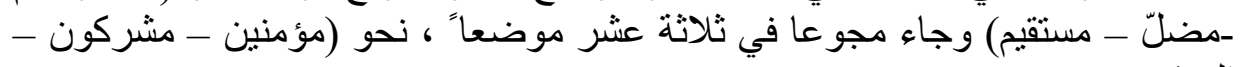

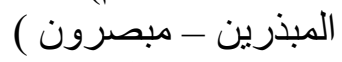

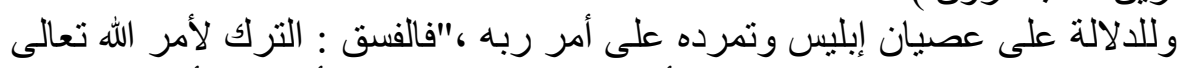
و العصيان ، والخروج عن طريق الحق أو الفجور ... وفسق عن أمر ربه ألترك ألي جار ومال

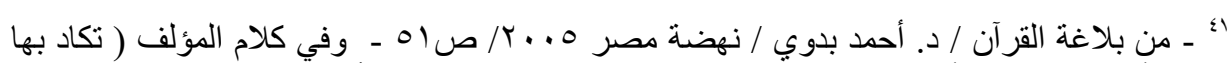

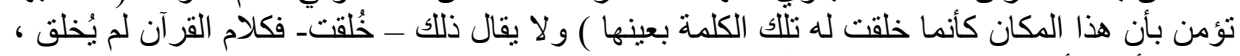

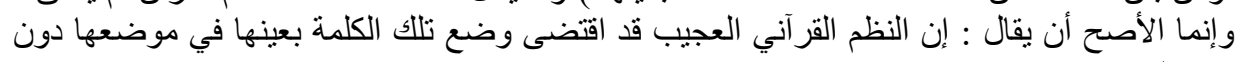

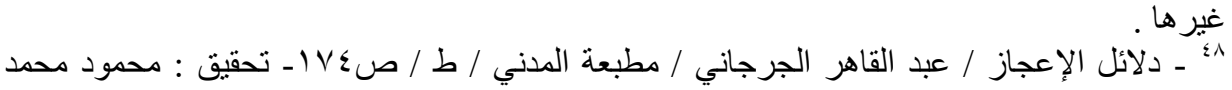

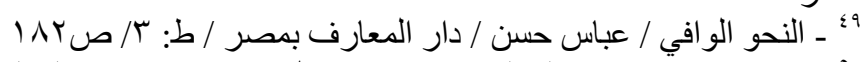

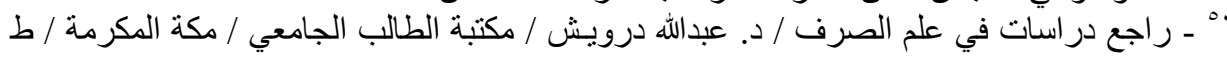


عن طاعته ، والعرب تقول إذا خرجت الرطبة من قثرها قد فسقت الرطبة من

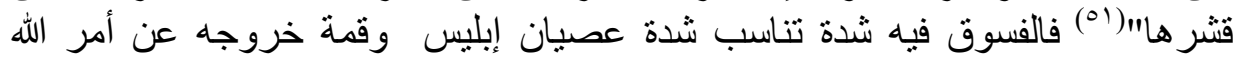

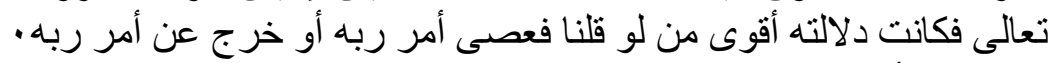

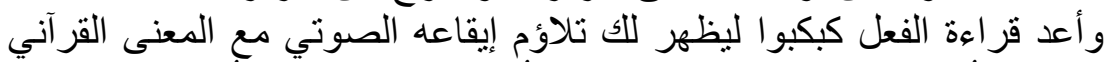

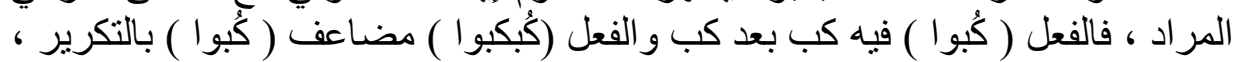

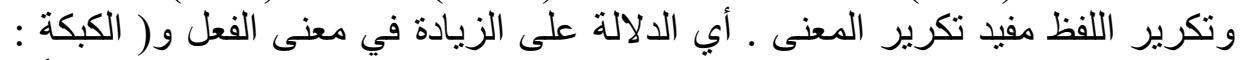

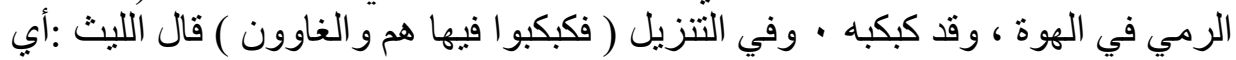

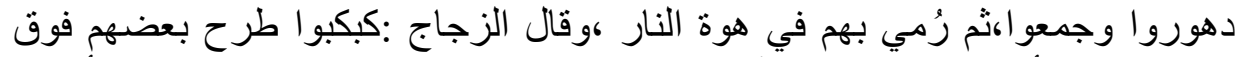

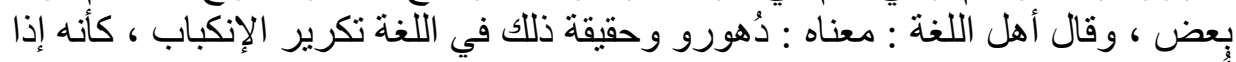

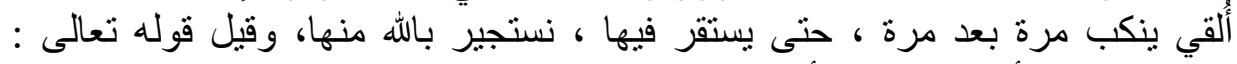

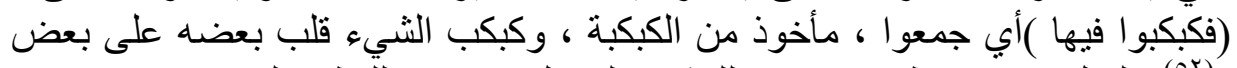

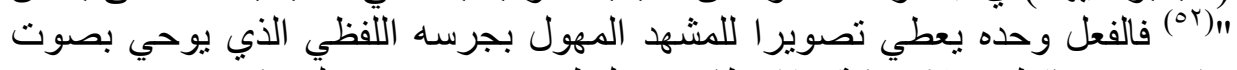

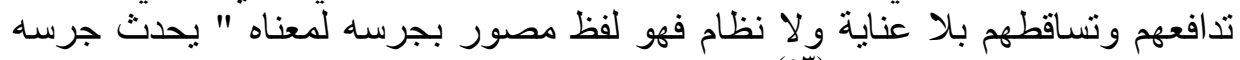

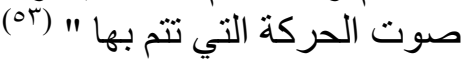

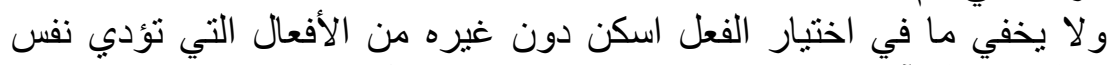

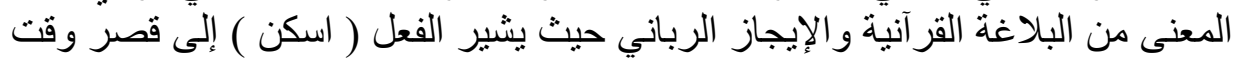

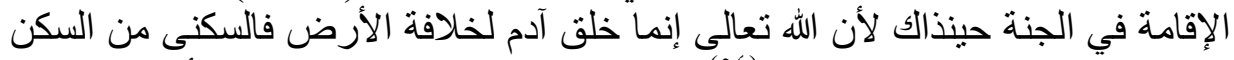

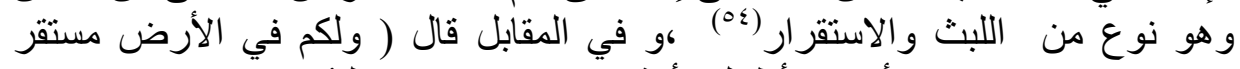

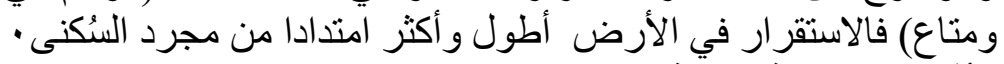

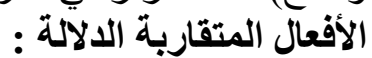

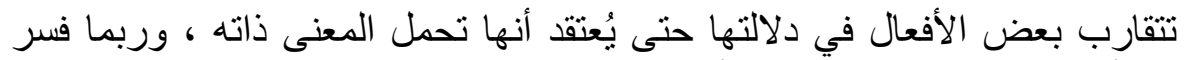

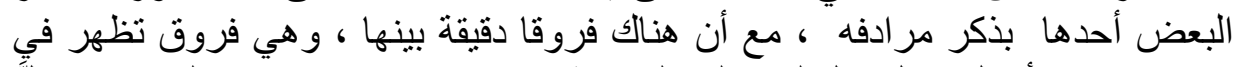

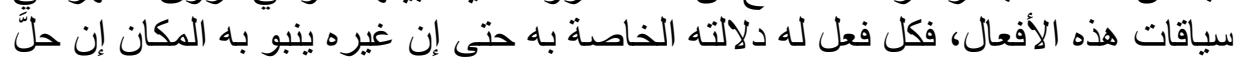

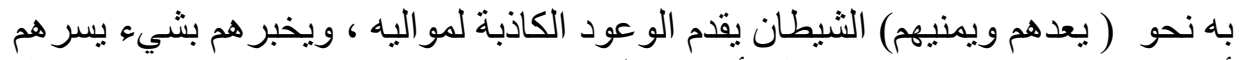

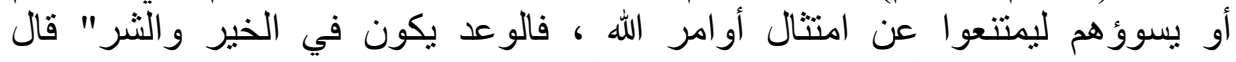

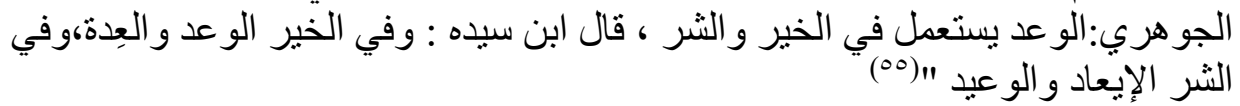

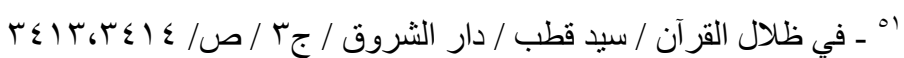

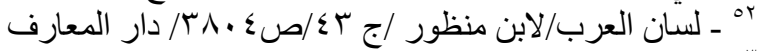

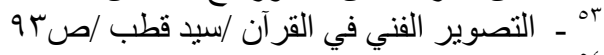

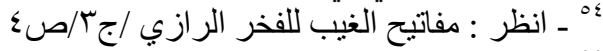

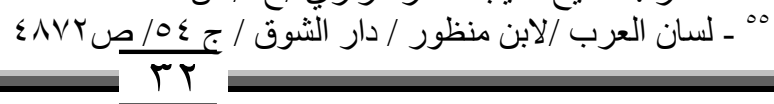




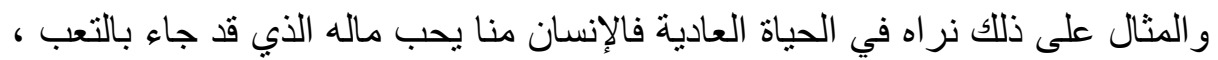

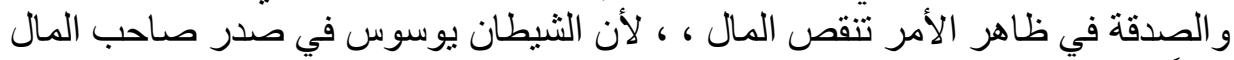

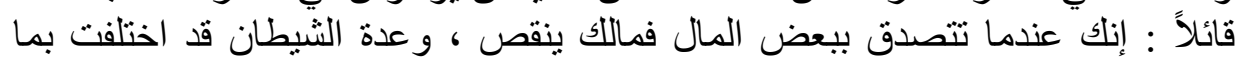

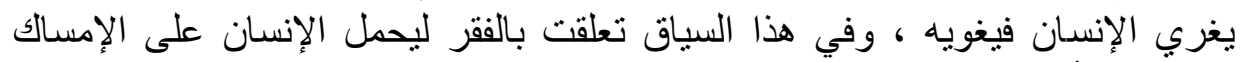

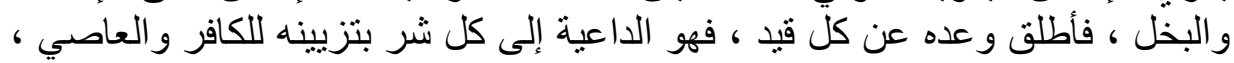

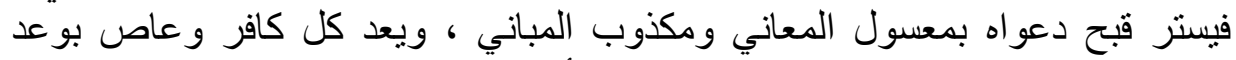

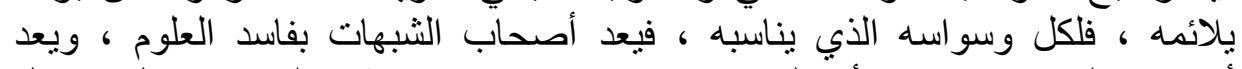

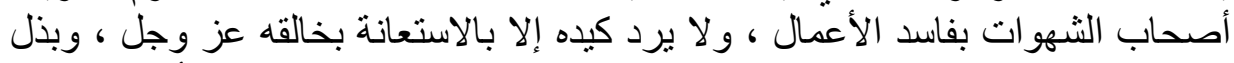

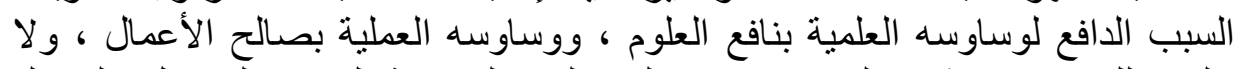

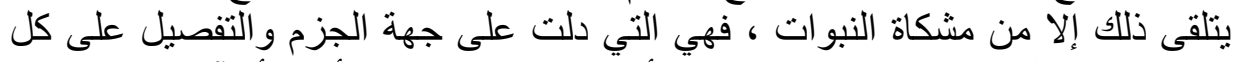

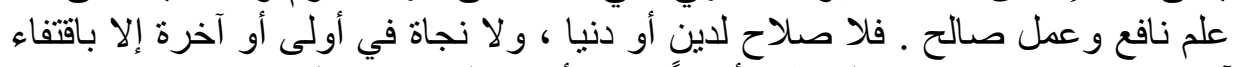

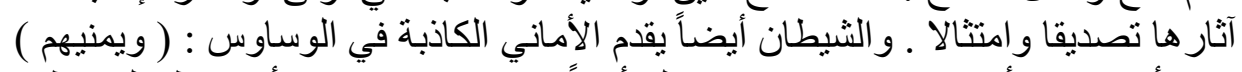

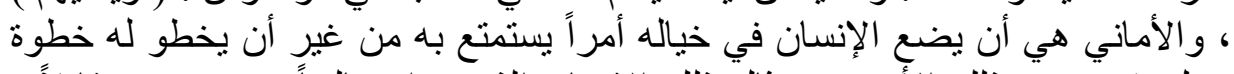

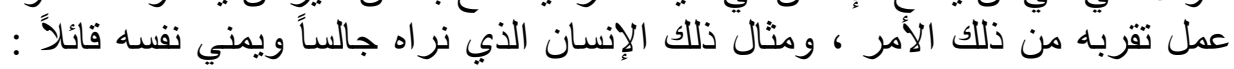

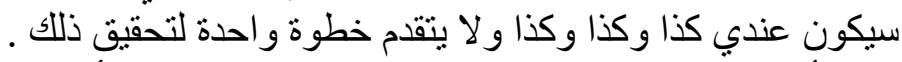

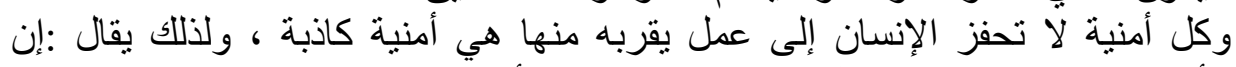

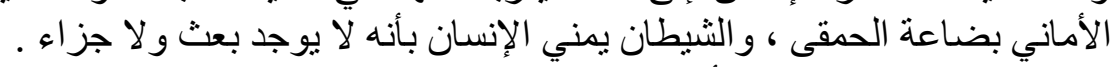

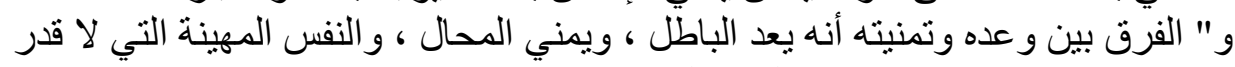

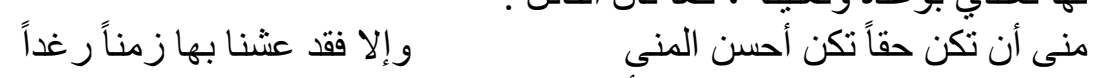

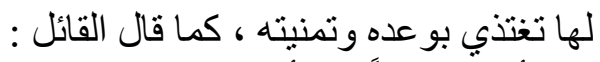

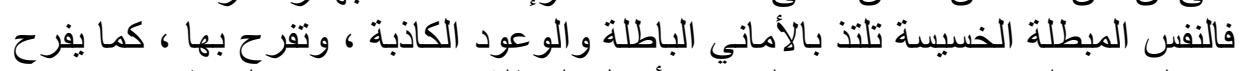

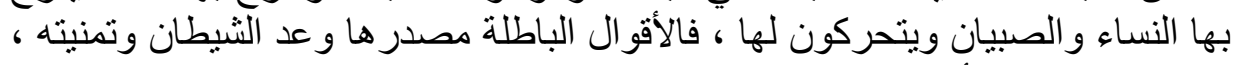

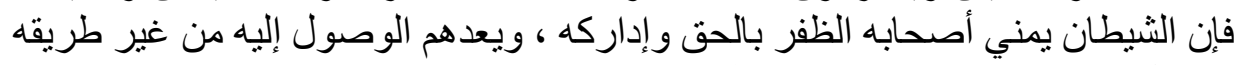

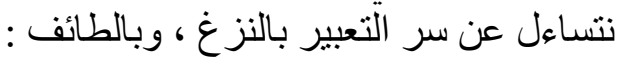

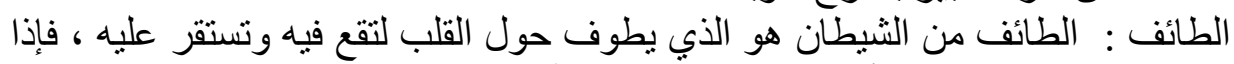
طاف الثيطان بالإنسان و أبعده عن طاعة الفي الله (تذكّر ).

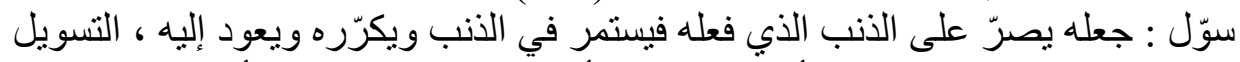

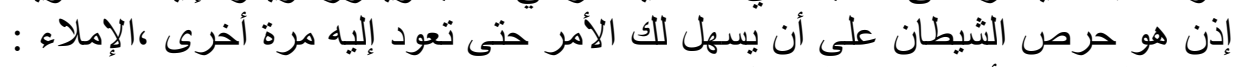

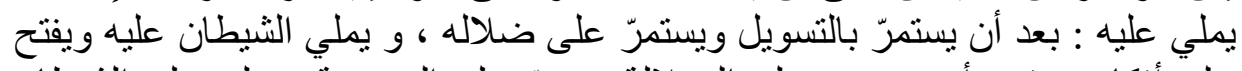

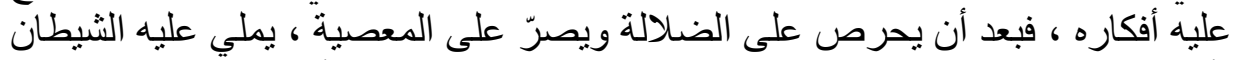

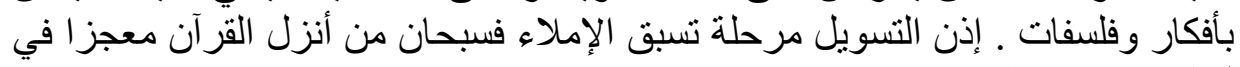
لفظه و معناه و نظمه و ومبناه. 


\section{المبحث الثاني

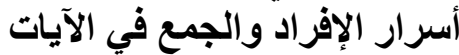

ضدمت دراسة الإفراد واد والجمع في القرآ آن الكريم الكثيرَ من النكات والأسرار

البلاغية.

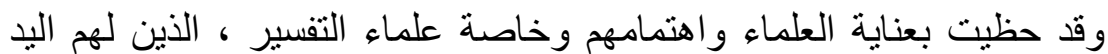

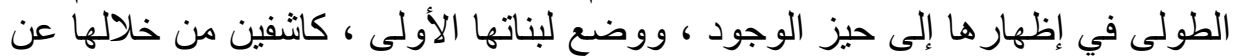

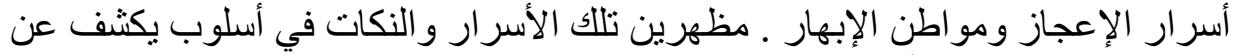

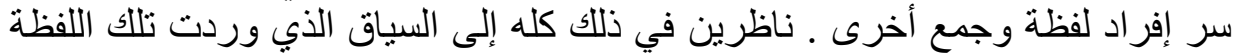

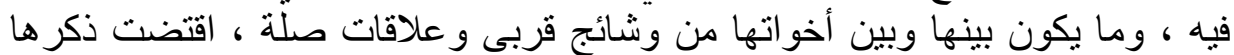

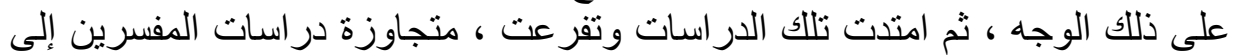

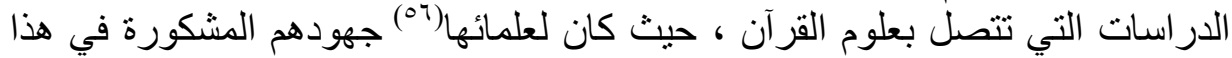
المجال .

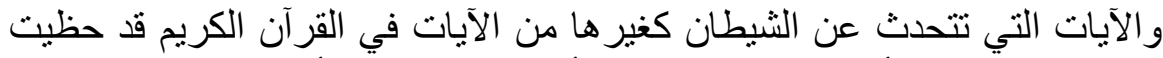

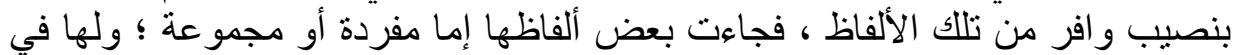

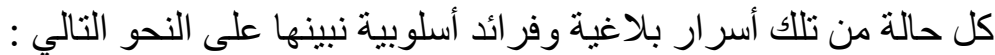

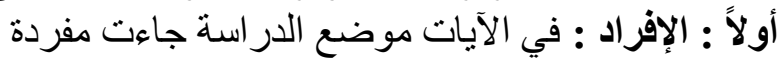

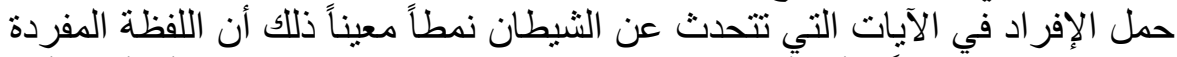

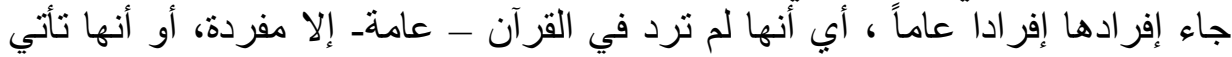

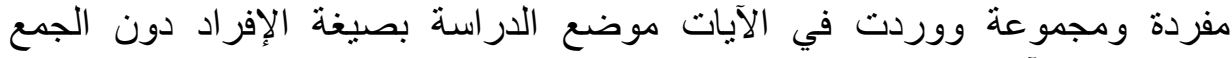

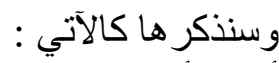

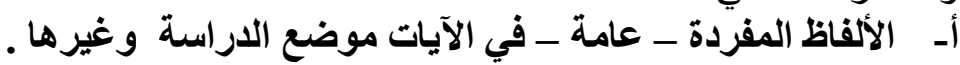
الصراط : لألمدرة

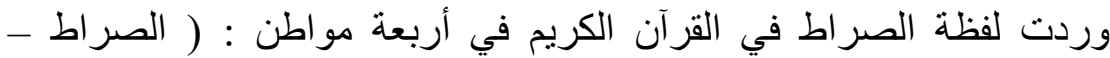

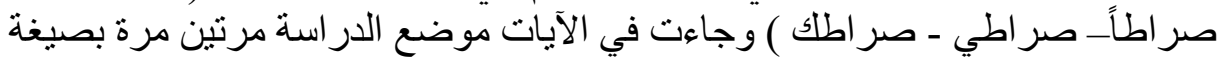

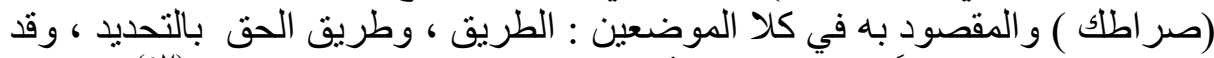

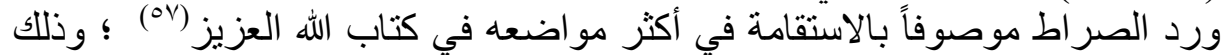
لوضوحه وسهولة السير فيه ـ ولعل السر في إيثار القرآن التعبير ( بالصر اط فئر ) مفردا 
دون الجمع (صرط ) وضوح الحق وبروز معالمه دائماً فالحق طريقه واحد خلافاً

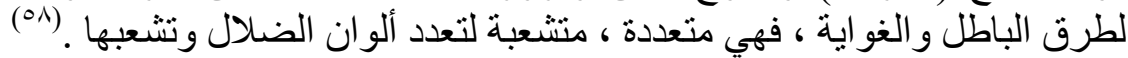

لفظة الأرض جاءت مفردة في هذه الآيات لأن السياق بقتضي ذلانك فالآية

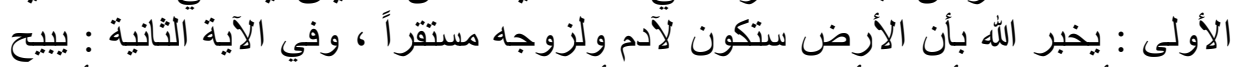

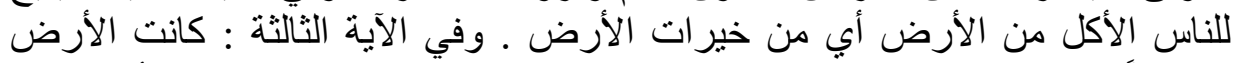

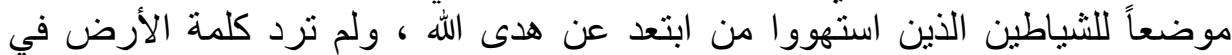

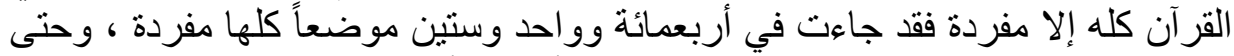

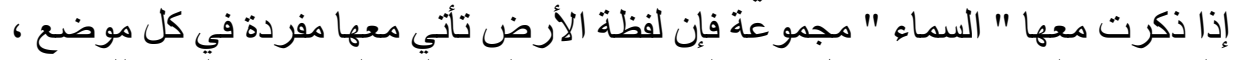

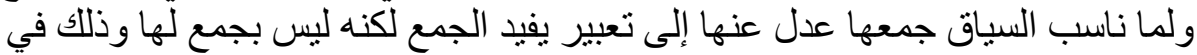

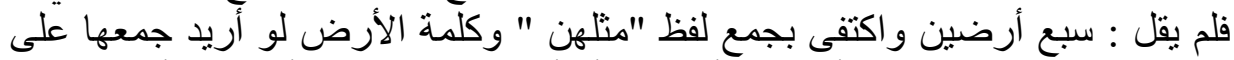

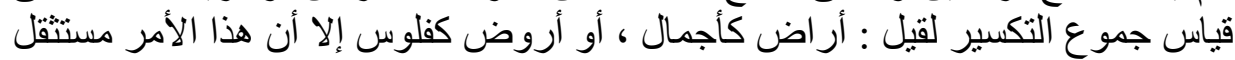

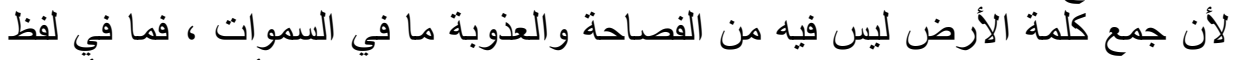

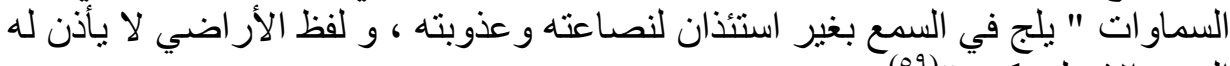

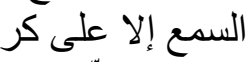

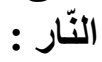

ورد لفظ النار على وجه الوعيد لمن عاد للربا والتعامل به ا"فلفة النار بظلالها

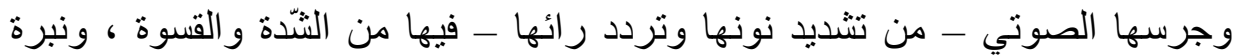

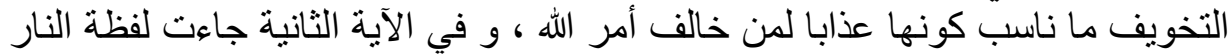

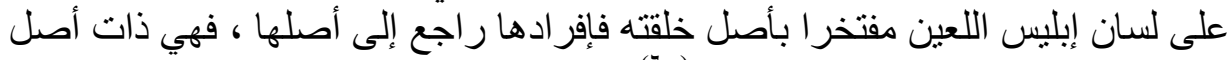

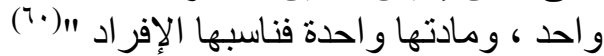

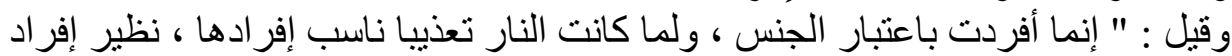

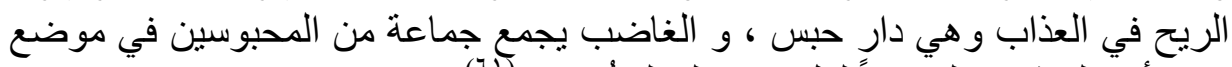

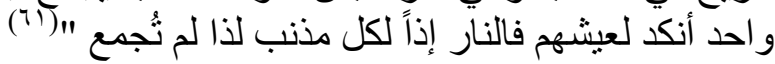

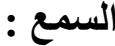

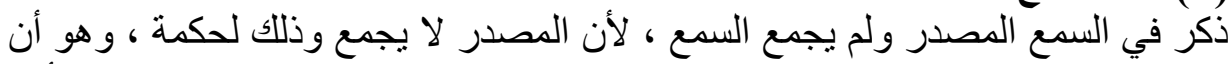
السمع قوة واحدة وله فعل واحد ، فإن الإنسان لا يضبط في زمان واحد لاحس كلامين ، و الأذن

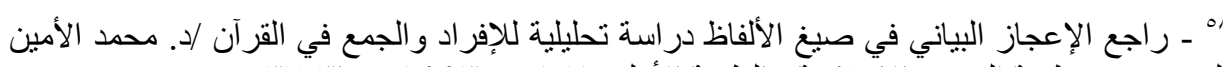

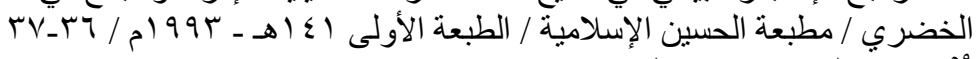

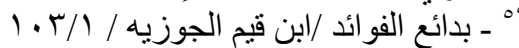

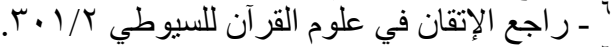

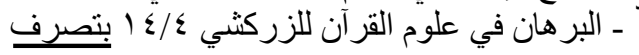




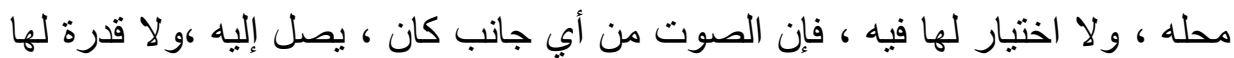

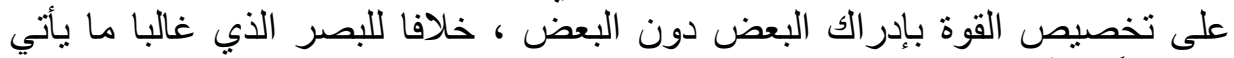

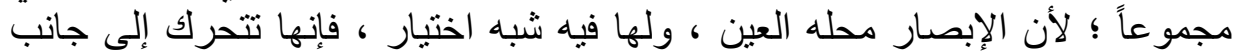

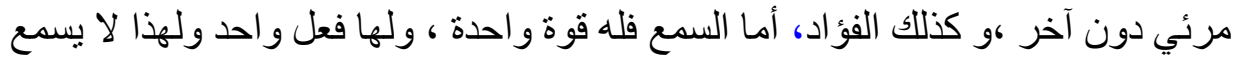

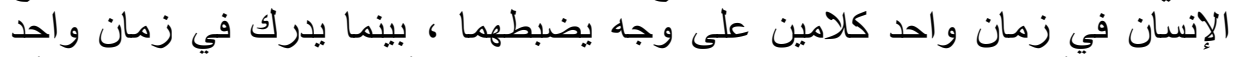

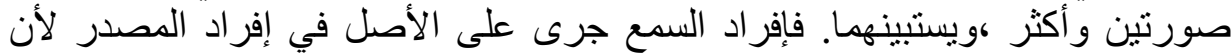

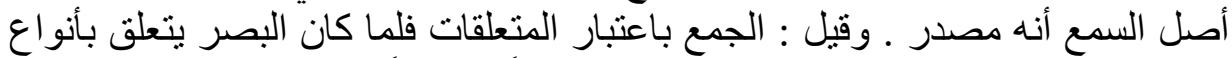

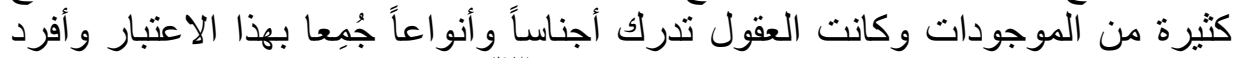

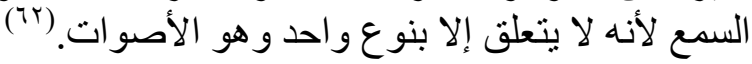

\section{بـ الألفاظ التي جاعت بالإفراد والجمع وذكرت في الآيات موضع الاراسة مفردة :}

(1) (السماء : (1)

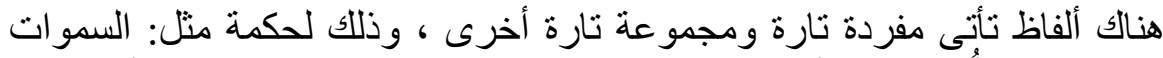

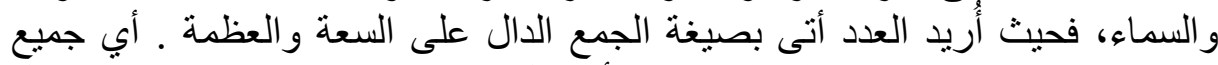

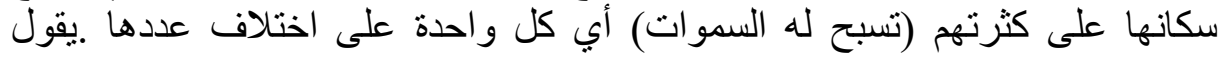

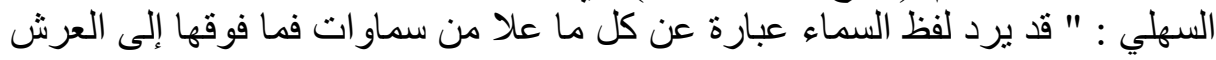

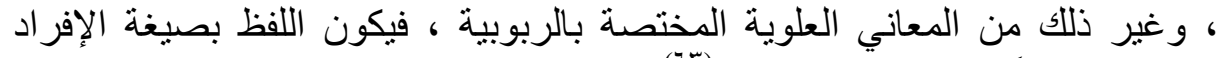

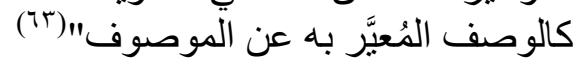

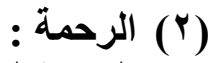

الرحمة لفظ رقيق دال على معناه ، ورد في القرآن بالجمع والإفر اد ، وفي الردي الآيات

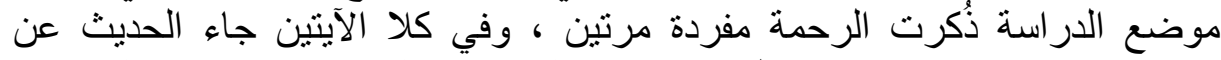

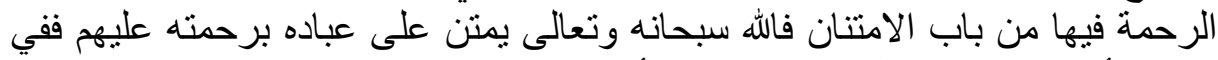

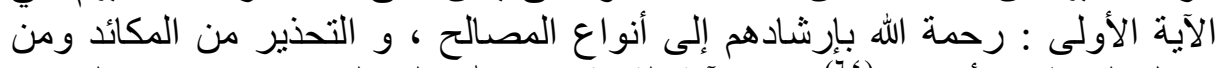

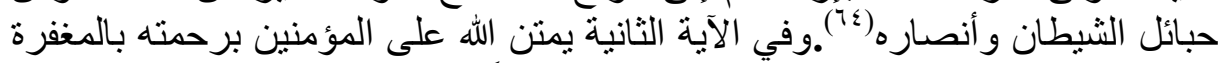

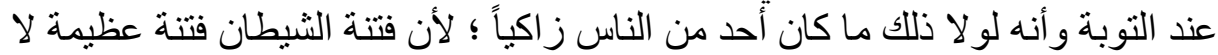

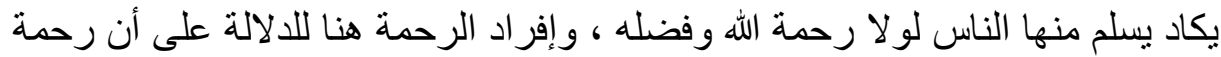

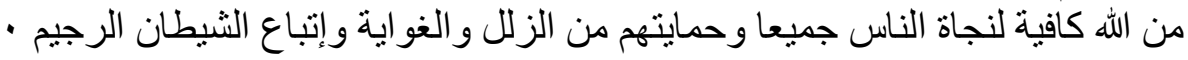

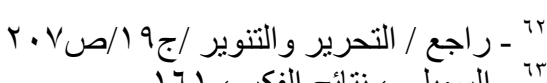

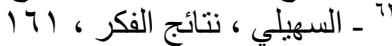

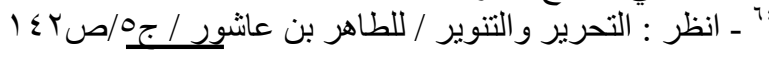




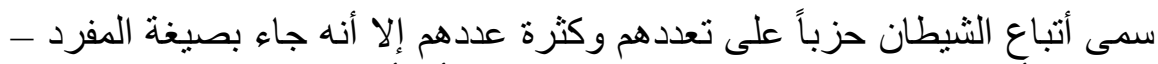

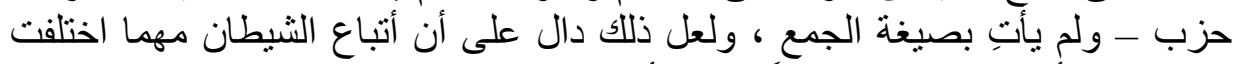

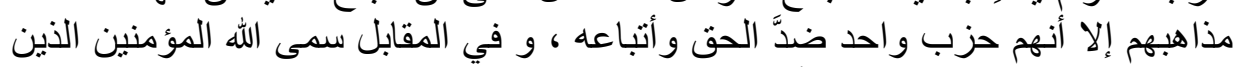

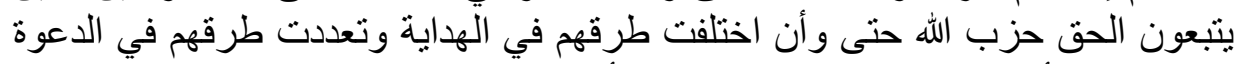

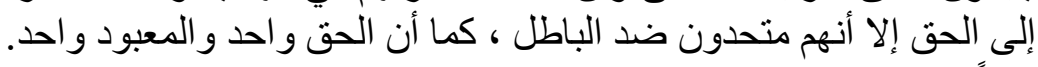

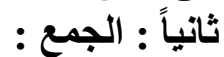

جاءت ألفاظ عديدة في الآيات موضع الدر اسة بصيغة الجمع دون الإفراد ، و هو هي

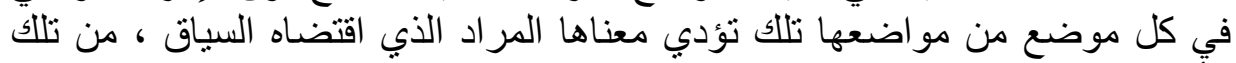

وردت لفظة ( همزات ) في القرآن مرة واحدة تعليماً لنبيه عليه السلام كيفية

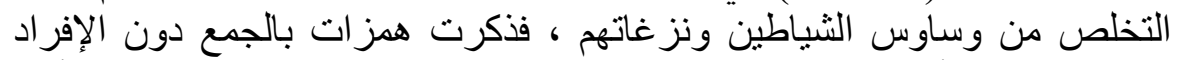

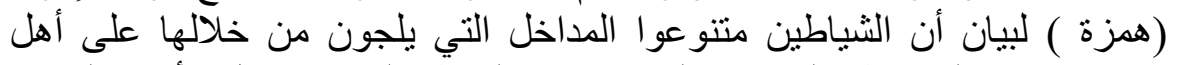

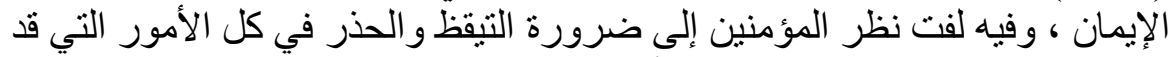

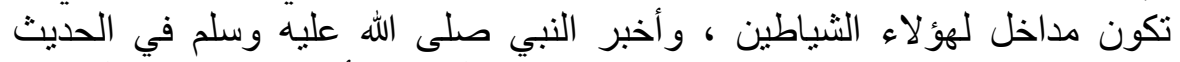

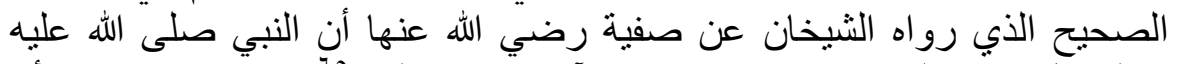

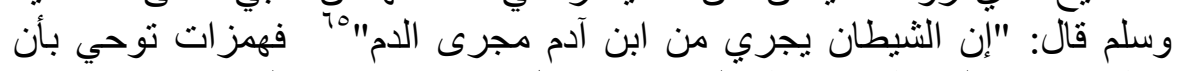

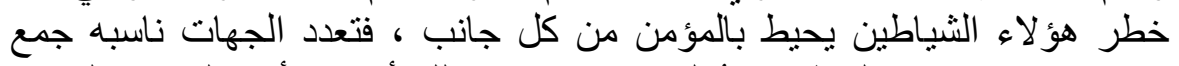

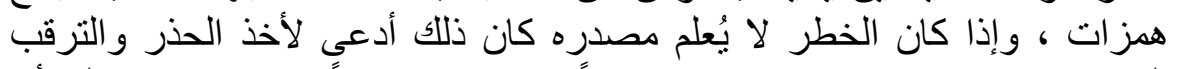

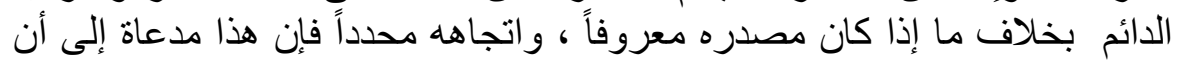

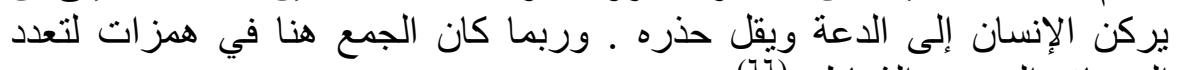

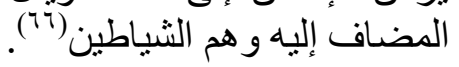
خطوات :

وردت لفظة ( خطوات ) في القرآن الكريم مجموعة ومضافة إلى الثيطان أربع

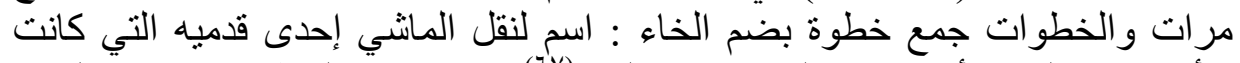

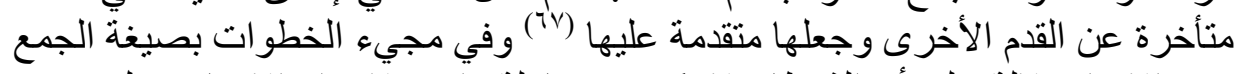

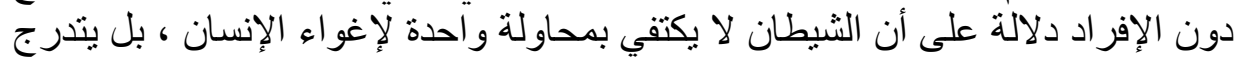

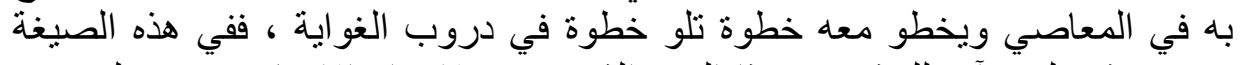

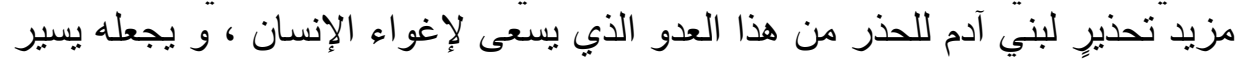

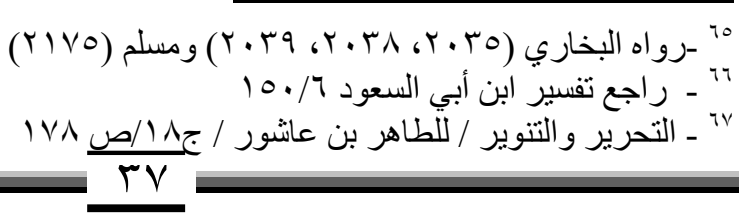


في سبل الغواية خطوة بسيطة لا يشعر بها ، ويتبعها بخطوة أخرى حتى تتابع خطواته ،

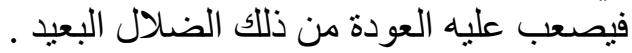
أصحاب : (r)

لفظ صاحب وردت في القرآن مفردة ومجمو عة ، وليس هنا مجال بحثنها ، و وإنما

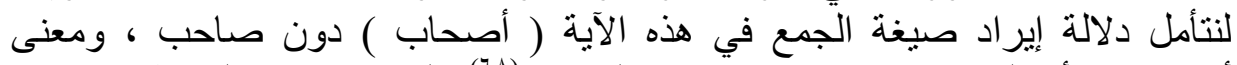

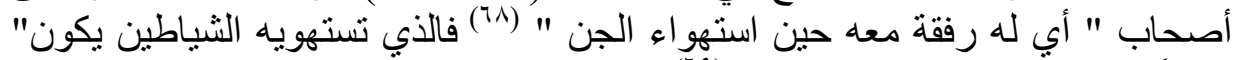

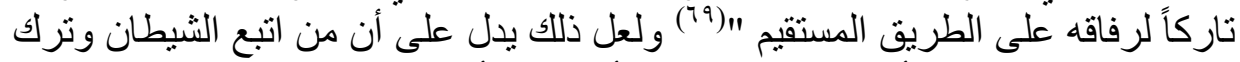

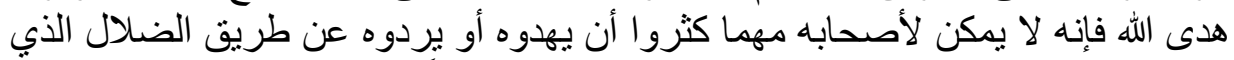

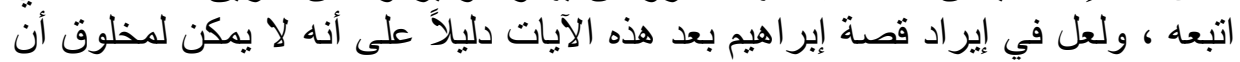

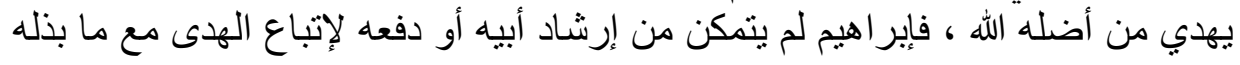

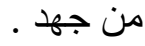 المبحث الثالث

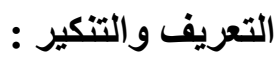
تعد دراسة التعريف و التنكير في الدرس البلاغي من أكثر المباحث البلاغية ثراءً

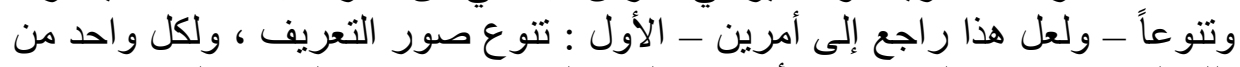

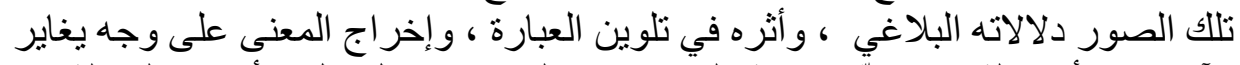

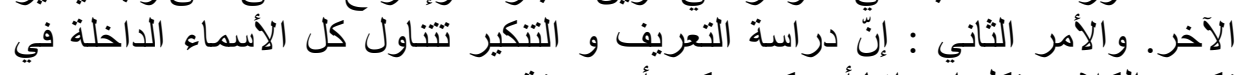

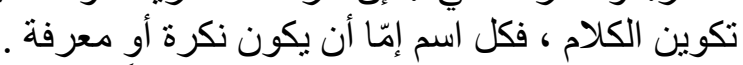

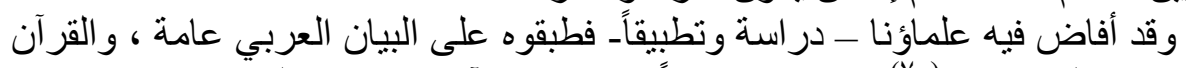

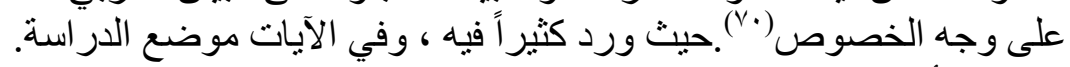

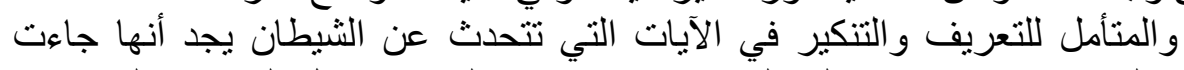

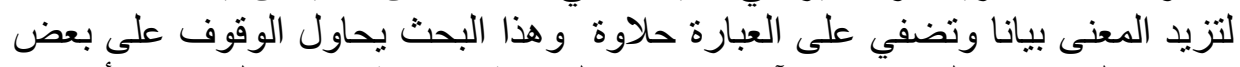

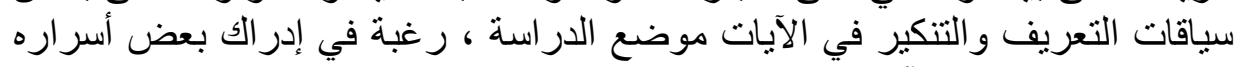
ولطائفه في السياق القراتئ آني. أولا:التعريف في الآيات التي التيات آتحدث عن الثيطان :

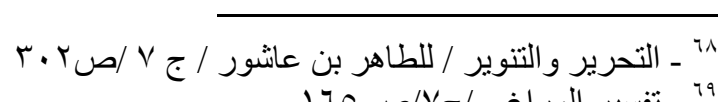

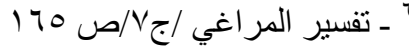

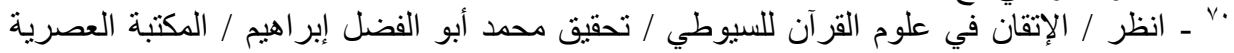

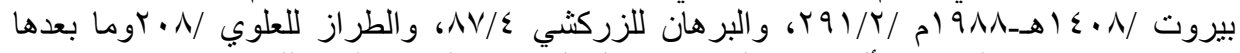

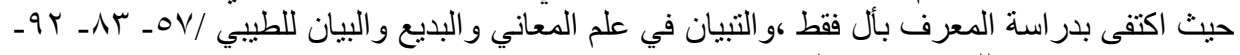

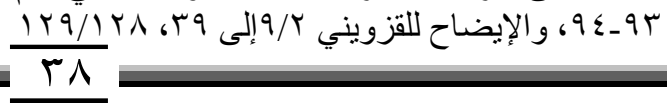




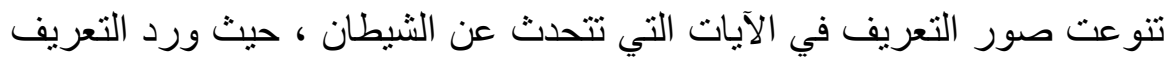

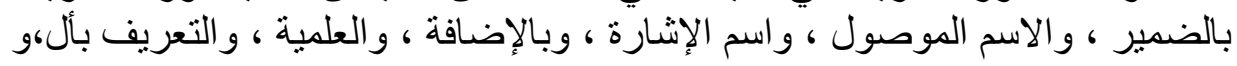
تفاوتت في كثرتها وهي على الاست النحو الآتي : الإني : (1)

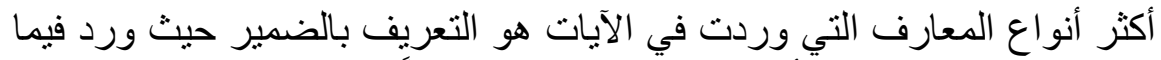

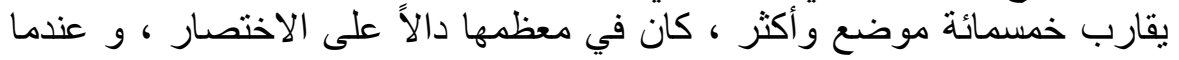

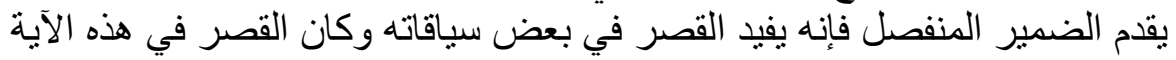

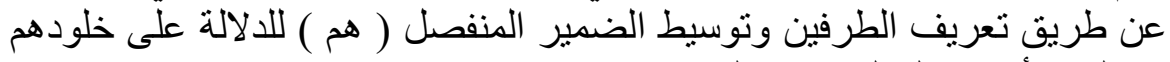

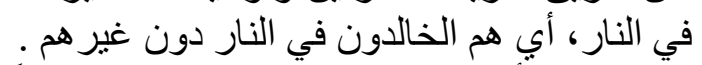

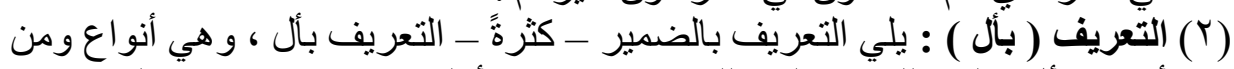

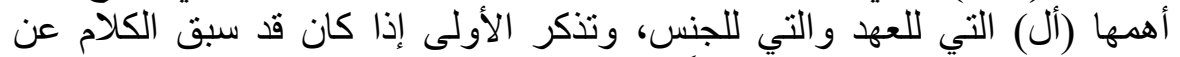

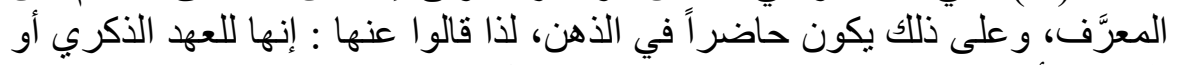

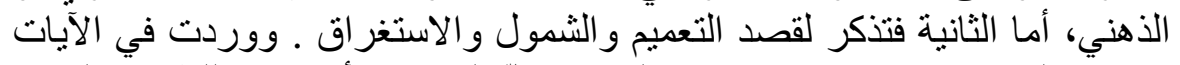

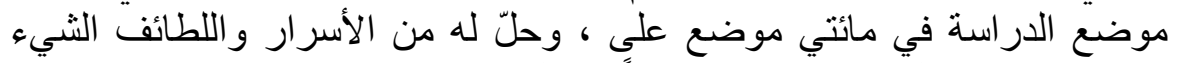

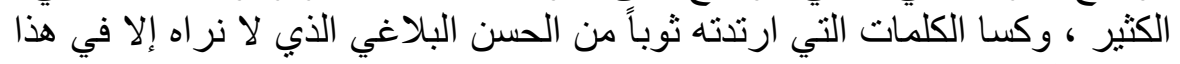

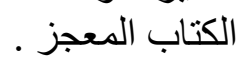
التعريف بالإضافة الإنة

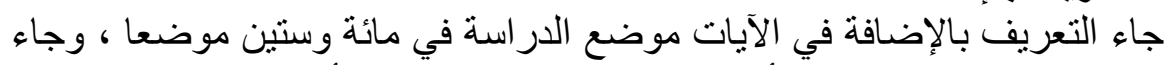

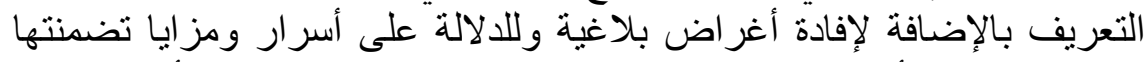

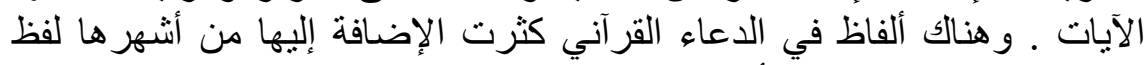

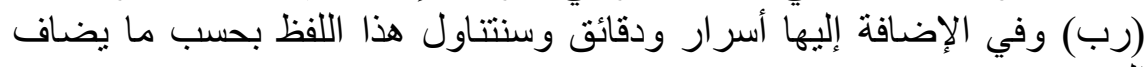

التعريف بالإضافة : الإهاءة

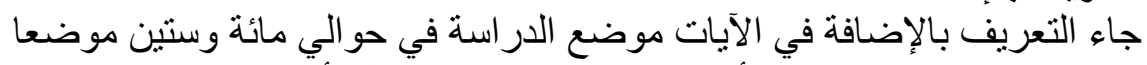

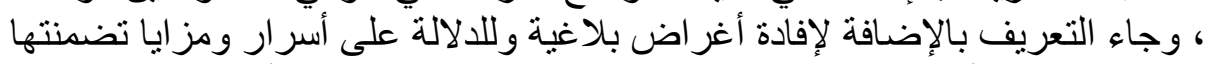

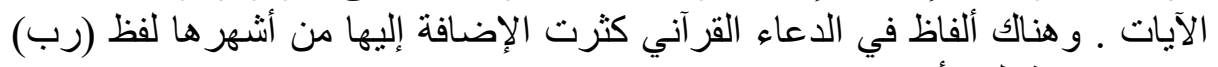
وفي الإضافة إليها أسرار ودقائق الأبعاء

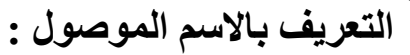

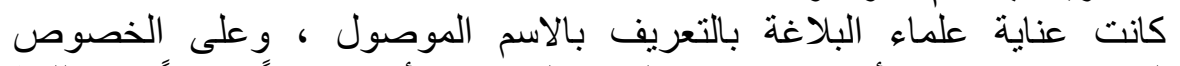
لفظ(الذي) ، كبيرة حتى أن الإمام عبد القاهر الجرجاني أفرد فصلاً خاصـاً بهذا اللفظ الفي 


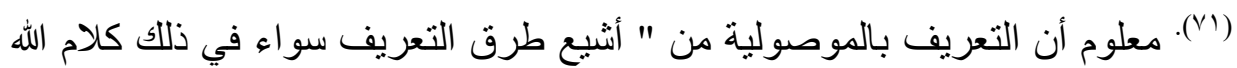

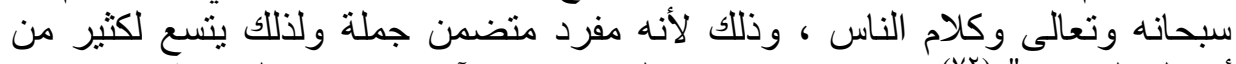

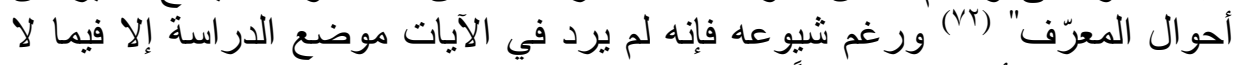

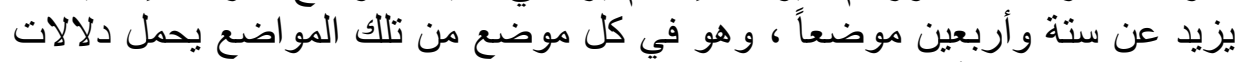

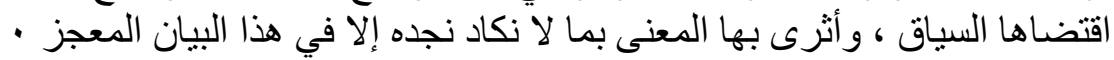
الفصل الثالث الثباق الثناول المبحث الأول الفمل المبات علاقات الجمل

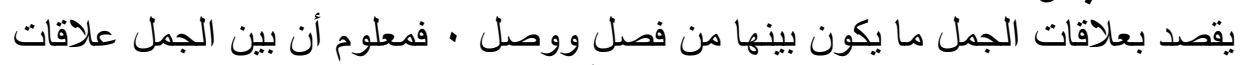

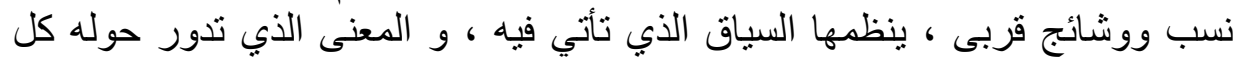

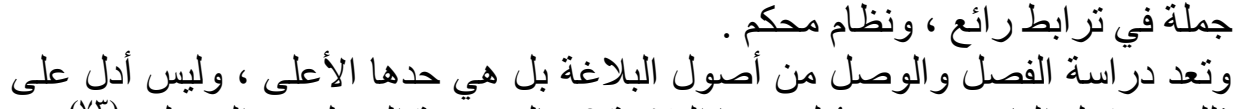

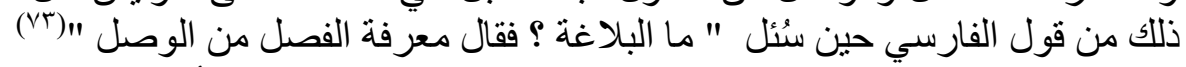

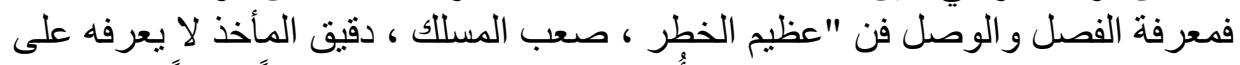

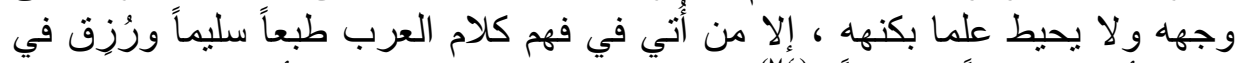

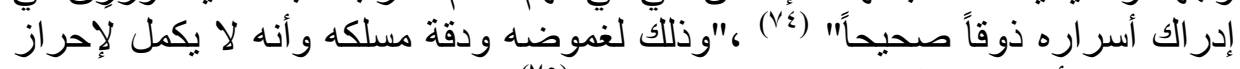

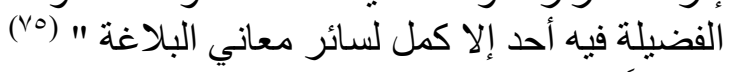

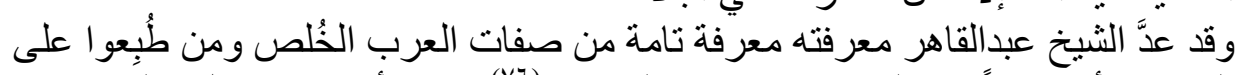

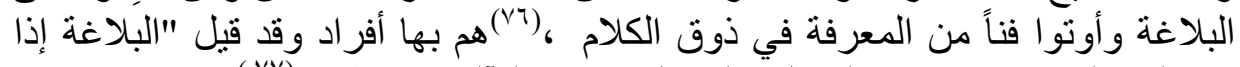

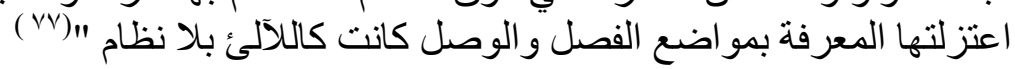

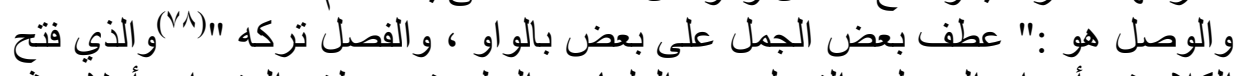

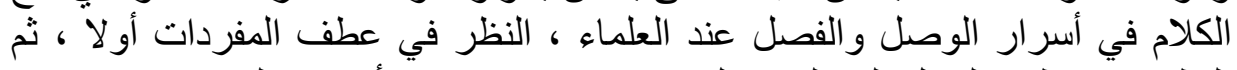

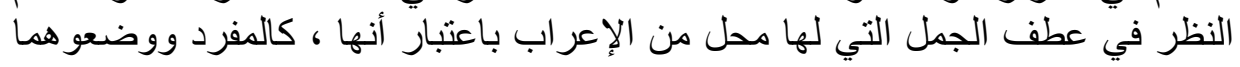

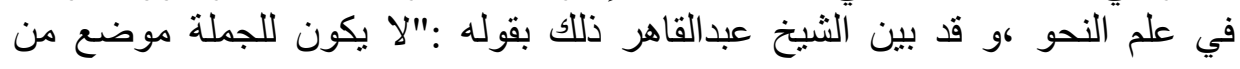

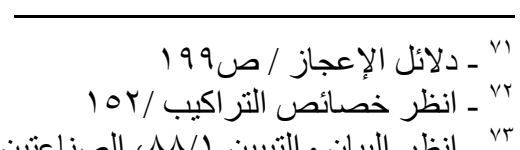

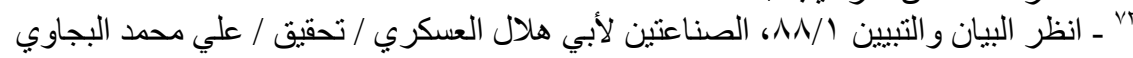

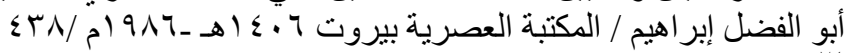

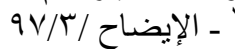

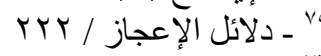

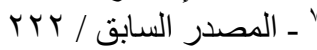

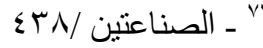

" - الإيضاح 
الإعراب حتى تكون و اقعة موقع المفرد ـ و إذا كانت الجملة الأولى و اقعة موقع المفرد

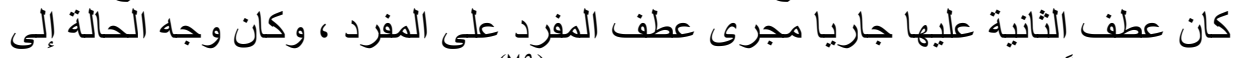

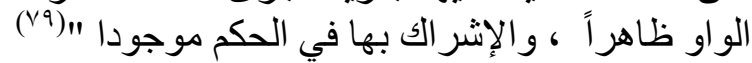

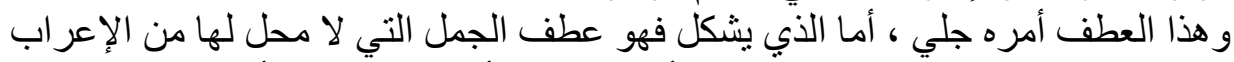

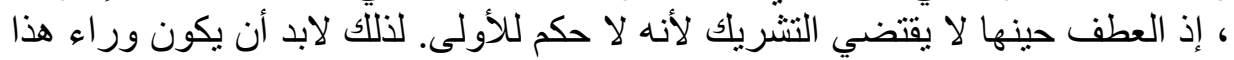

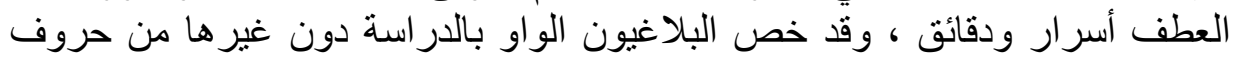

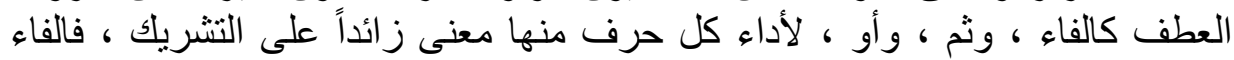

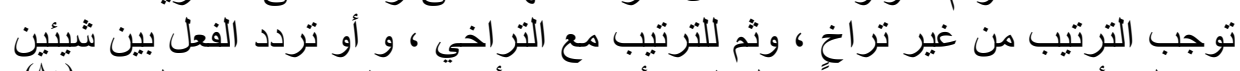

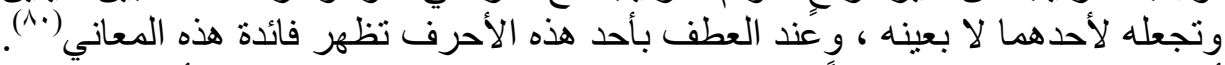

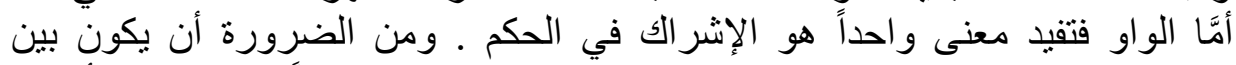

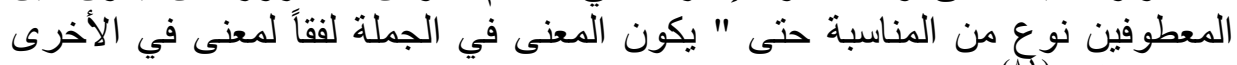

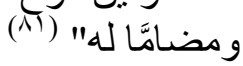

\section{المبحث الثاني}

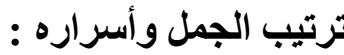

حظي القرآن الكريم بنصيب وانبرانه وافر من دراسة ترتيب الجمل على أيدي المتقدمين

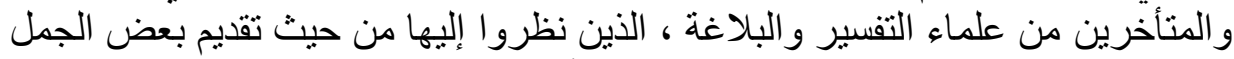

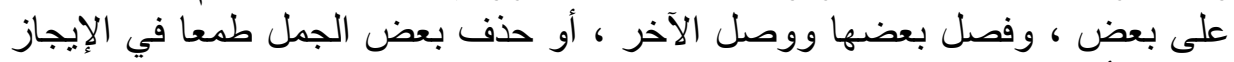

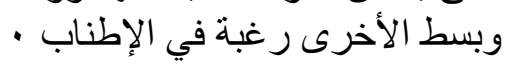

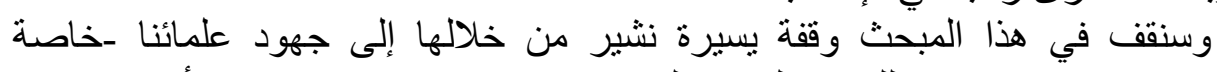

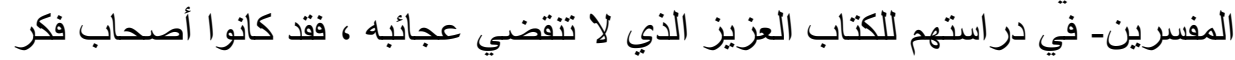

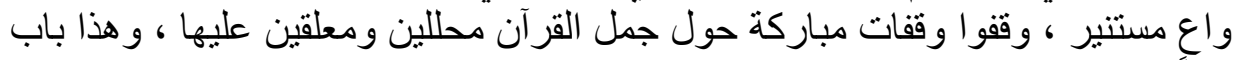

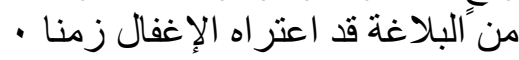

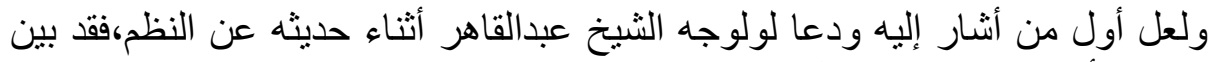

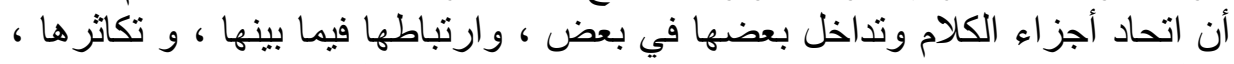

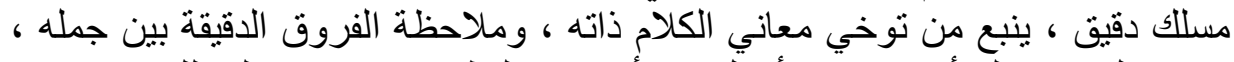

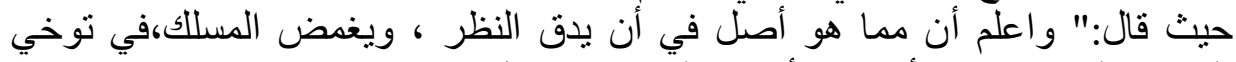

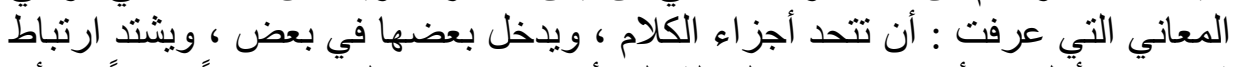

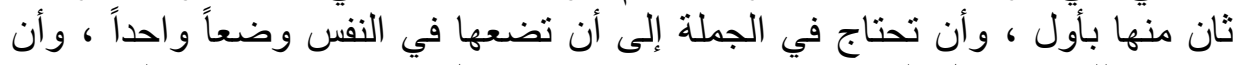

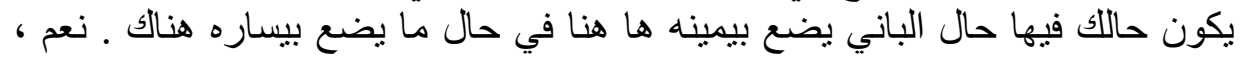




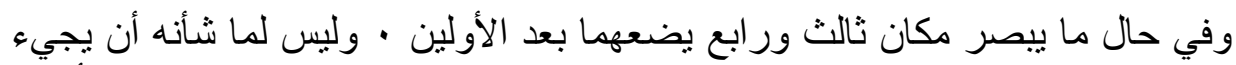

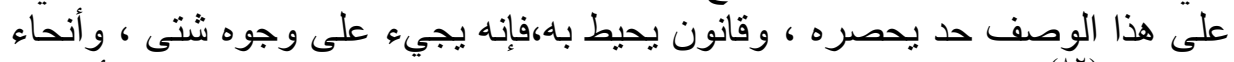

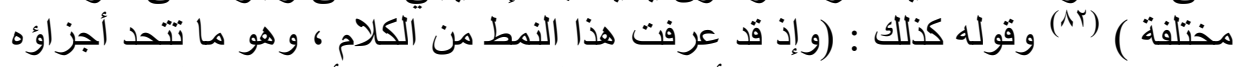

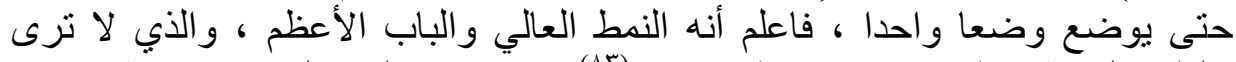

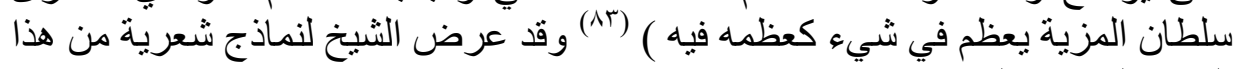

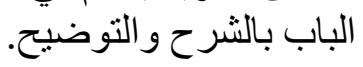
و هو بكلامه هذا قد فتح بابا عظيما لدر اسة تر اكيب الكلام و تكوينات الجمل .

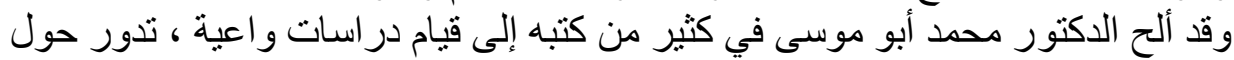

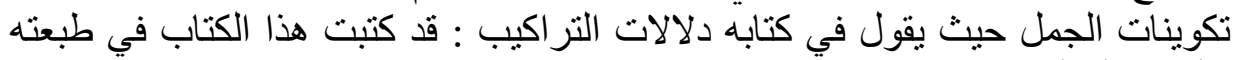

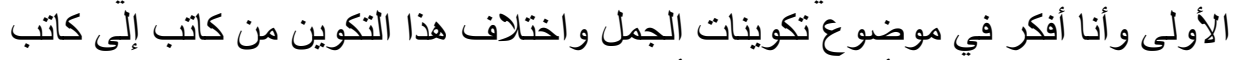

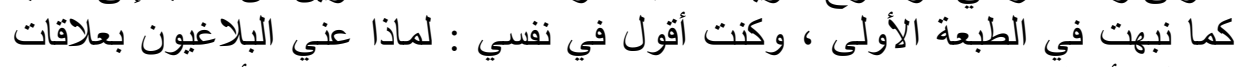

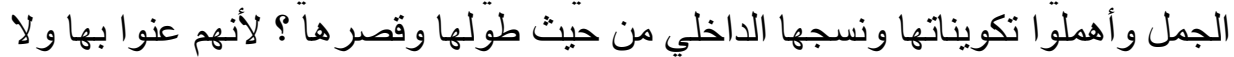

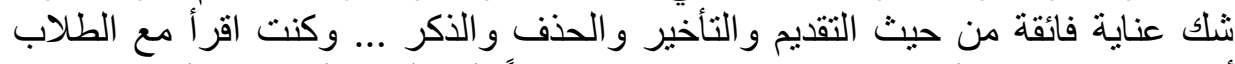

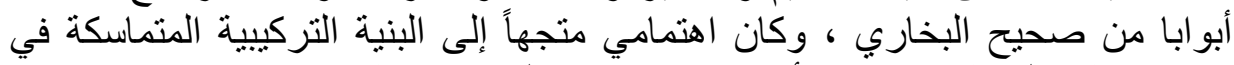

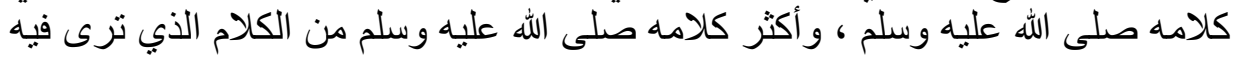

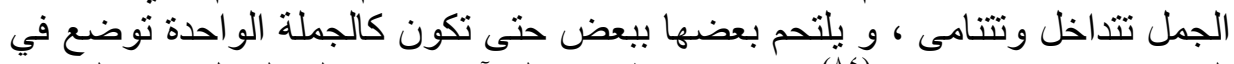

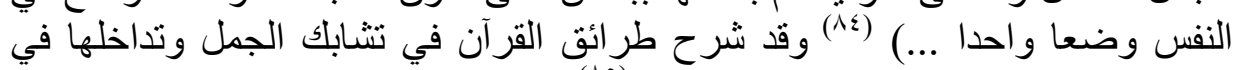

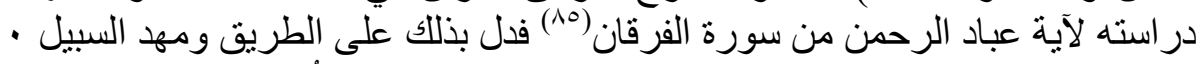

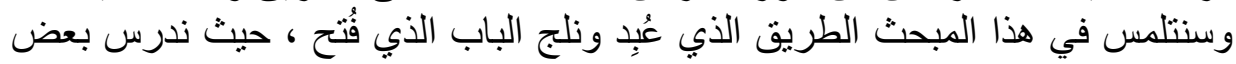

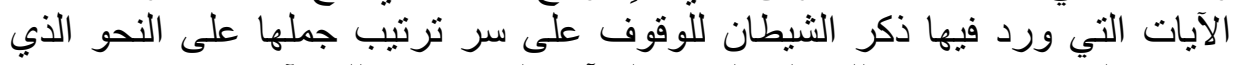

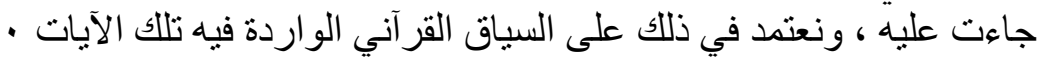

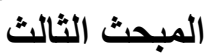
مظاهر الإيجاز والإطناب الإبـ يعد الإيجاز والإيجاز والإطناب من أبواب البلابة الإباب المهمة ، وقد تناولها الدارسون بالتفصيل

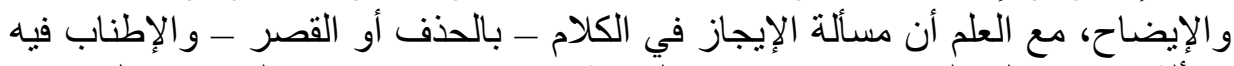

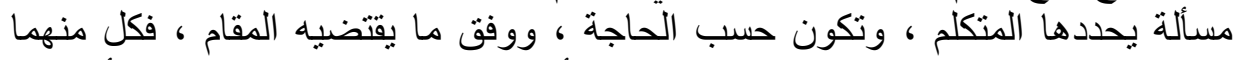

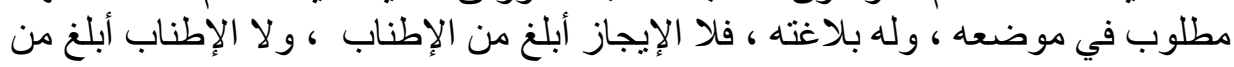

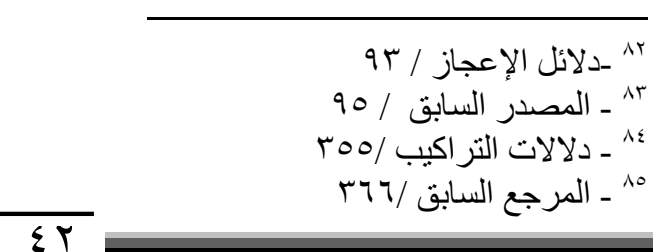




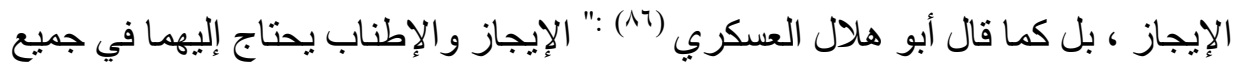

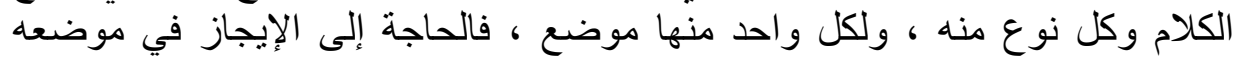

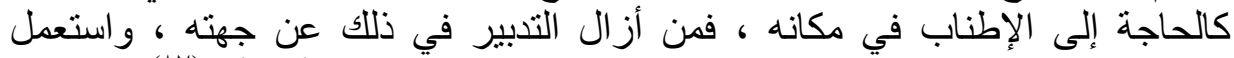

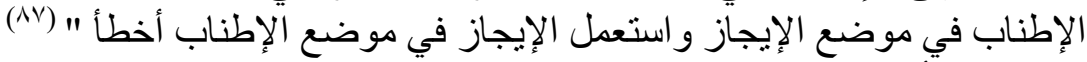

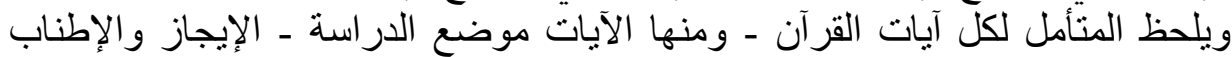

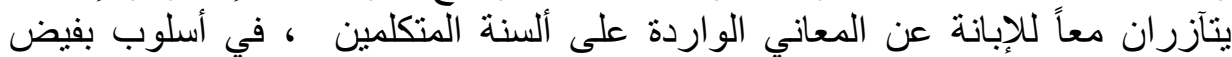

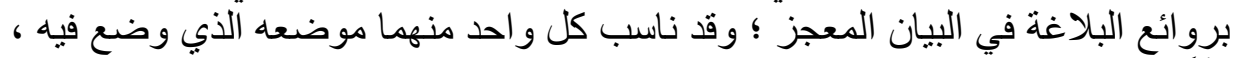

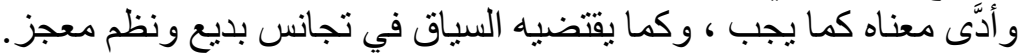

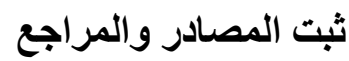

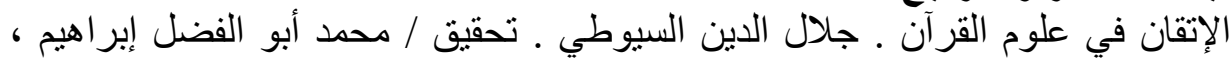

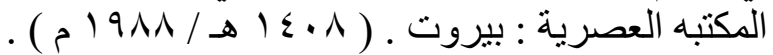

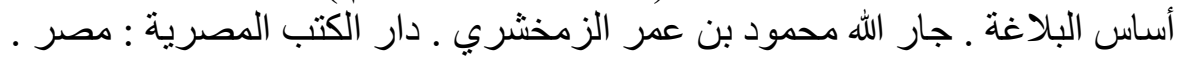

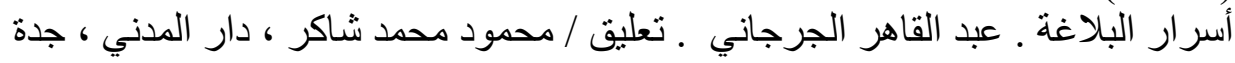

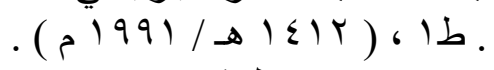

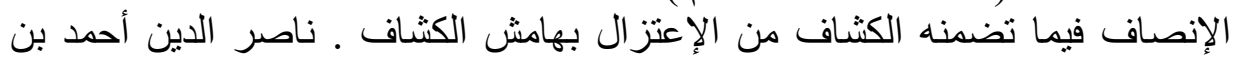

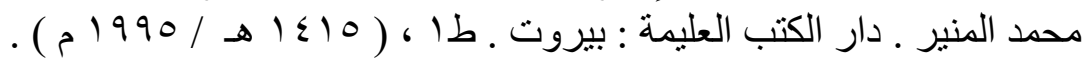

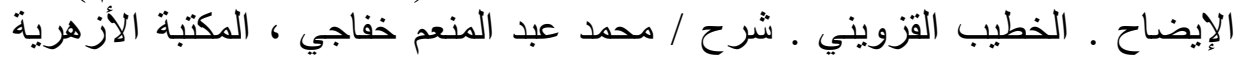

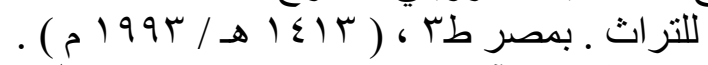

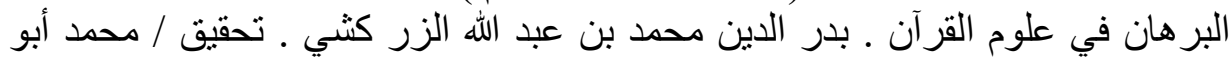

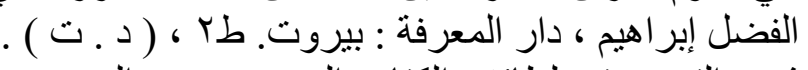

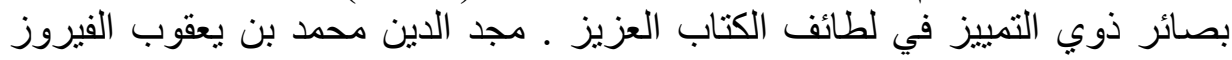

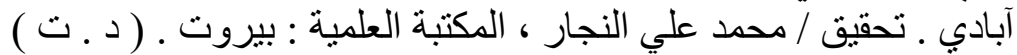

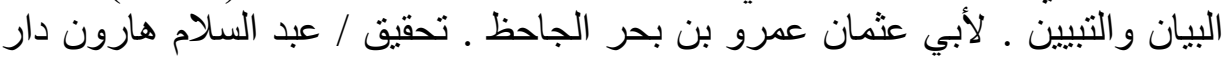

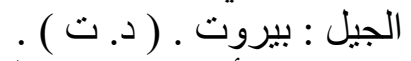

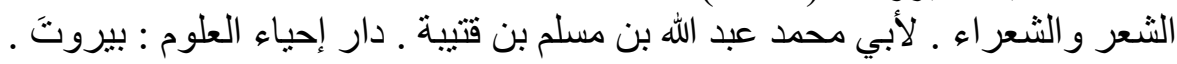

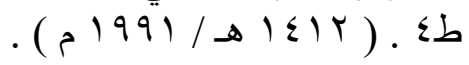

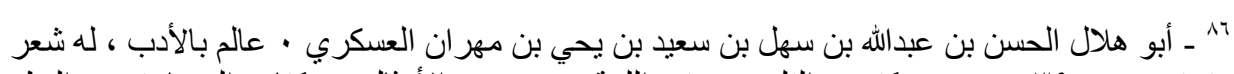

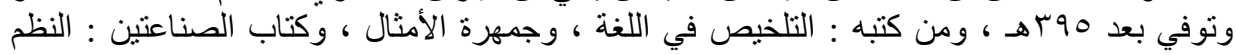




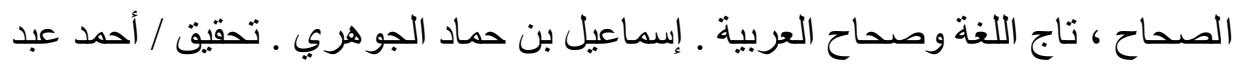

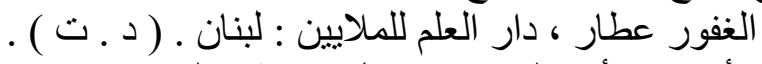

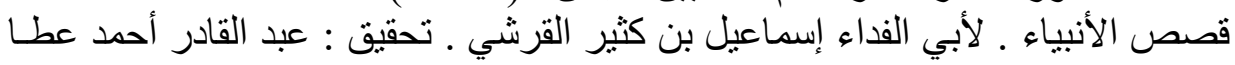
، المكتبة الإسلامية : بيروت الأبية أبيل بن 